\title{
Archaeological Investigations at Mission Concepción and Mission Parkway
}

James E. Ivey

Anne A. Fox

Follow this and additional works at: https://scholarworks.sfasu.edu/ita

Part of the American Material Culture Commons, Archaeological Anthropology Commons, Environmental Studies Commons, Other American Studies Commons, Other Arts and Humanities Commons, Other History of Art, Architecture, and Archaeology Commons, and the United States History Commons

Tell us how this article helped you.

This Article is brought to you for free and open access by the Center for Regional Heritage Research at SFA ScholarWorks. It has been accepted for inclusion in Index of Texas Archaeology: Open Access Gray Literature from the Lone Star State by an authorized editor of SFA ScholarWorks. For more information, please contact cdsscholarworks@sfasu.edu. 


\section{Archaeological Investigations at Mission Concepción and Mission Parkway}

Creative Commons License

(c) $)$ (i) @

This work is licensed under a Creative Commons Attribution-NonCommercial 4.0 International License 


\title{
Archaeological Investigations at Mission Concepción and Mission Parkway
}

\author{
James E. Ivey and Anne A. Fox \\ with contributions by \\ William McGlure and Jay C. Blaine
}

Center for Archaeological Research

The University of Texas at San Antonio Archaeological Survey Report, No. 114 1999 



\title{
Archaeological Investigations at Mission Concepción and Mission Parkway
}

\author{
James E. Ivey and Anne A. Fox
}

\author{
with contributions by \\ William McClure and Jay C. Blaine
}

Thomas R. Hester, Jack D. Eaton, Anne A. Fox and Robert J. Hard Principal Investigators

Texas Antiquities Permit No. 295

(ㄷ)1999

Center for Archaeological Research

The University of Texas at San Antonio

Archaeological Survey Report, No. 114 
The following information is provided in accordance with the General Rules of Practice and Procedure, Chapter 41.11 (Investigative Reports), Texas Antiquities Committee:

1. Type of investigation: Archival research and mitigation

2. Project name: Concepción

3. County: Bexar

4. Principal investigators: Thomas R. Hester, Jack D. Eaton, Anne A. Fox, and Robert J. Hard

5. Name and location of sponsoring agency: San Antonio Missions National Historical Park, National Park Service, San Antonio, Texas

6. Texas Antiquities Permit No.: 295

7. Published by the Center for Archaeological Research, The University of Texas at San Antonio, 6900 N. Loop 1604 W., San Antonio, Texas 78249-0658, 1999

A list of publications offered by the Center for Archaeological Research is available. Call (210) 458-4378; write to the Center for Archaeological Research, The University of Texas at San Antonio, 6900 N. Loop 1604 W., San Antonio, Texas 78249-0658; e-mail to car@lonestar.utsa.edu; or visit CAR's Web site at http://www.csbs.utsa.edu/research/car/index.htm. 


\section{Abstract}

In September 1980, the Center for Archaeological Research (CAR) entered into a contract (No. CX702900023) with the National Park Service (NPS) to conduct archaeological studies at Mission Concepción (41BX12). The studies would be designed to replot the original outline of the mission pueblo, to find the location of the mission granary, and to make an assessment of the state of preservation of the Indian quarters along the walls of the pueblo, all with minimum possible disturbance.

Preliminary research began in October 1980. During this phase, CAR located deed records and surveyor's notes dating from the 1820 s through the 1880 s in the Bexar County Courthouse which gave what appeared to be a reasonably accurate outline of the mission pueblo and the location of the granary. Subsequent fieldwork began in December 1980 . Over a period of 85 working days, fieldwork confirmed the results of the preliminary research. Excavations showed that the foundations of the east wall of the pueblo were well preserved, with the associated living surfaces of the Indian quarters still relatively undisturbed for much of its length. Portions of the north wall and its Indian quarters were equally well preserved. Occasional traces of the west and south walls were also found in a field which had been scraped smooth by a bulldozer some years ago. The granary foundations and those of several adjoining rooms, located in the process of positive identification of the granary, were in good condition in the ground, but most of their associated floor surfaces had been disturbed.

In several areas beneath the stone foundations of the final form of Mission Concepción, adobe walls of the first permanent mission buildings on the site were found. One of these structures appeared to be the first mission church of Concepción. Test excavations within the outlines of the building revealed seven burials beneath its floors.

As a result of the documents research, the original line of Mission Road was determined. This information is valuable in re-routing Mission Road around the remains of Mission Concepción.

An amendment to the above contract necessitated archaeological survey of a number of specific areas within the San Antonio Missions National Historical Park. Four proposed development areas in the immediate vicinity of the missions were surveyed. Twenty-two remote-sensing anomalies were examined and, where possible, were identified and/or explained. In addition, three large park areas were surveyed. Seven recorded historic and prehistoric sites and buildings were re-examined and their importance assessed. Four new archaeological sites were recorded. 


\section{Contents}

Abstract $\ldots \ldots \ldots \ldots \ldots \ldots \ldots \ldots \ldots \ldots \ldots \ldots \ldots \ldots \ldots \ldots \ldots \ldots \ldots \ldots$

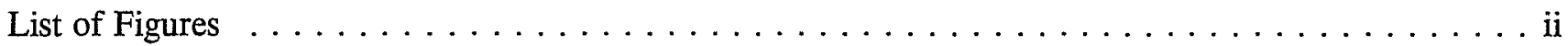

List of Tables $\ldots \ldots \ldots \ldots \ldots \ldots \ldots \ldots \ldots \ldots \ldots \ldots \ldots \ldots \ldots \ldots \ldots \ldots \ldots \ldots \ldots \ldots$

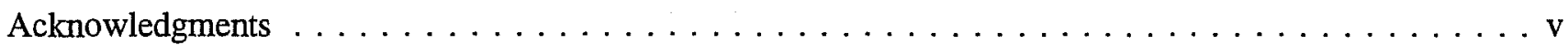

Management Summary $\ldots \ldots \ldots \ldots \ldots \ldots \ldots \ldots \ldots \ldots \ldots \ldots \ldots$ vii

Part I: Introduction, Setting, and Historical Background

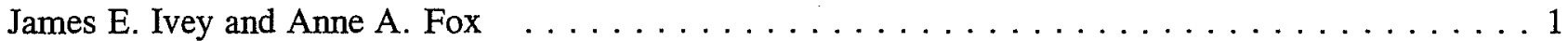

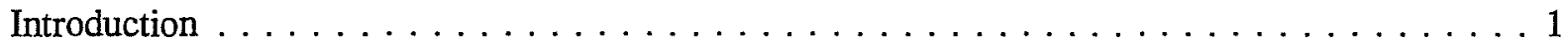

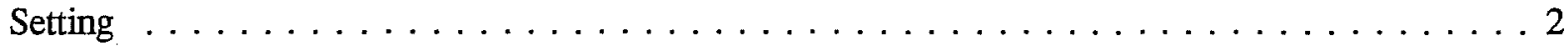

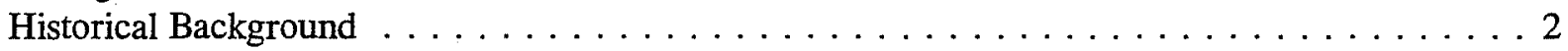

Part II: Excavations at Mission Concepción

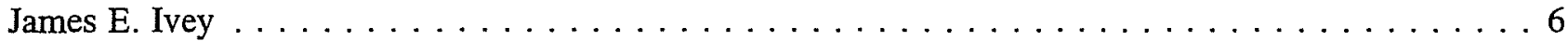

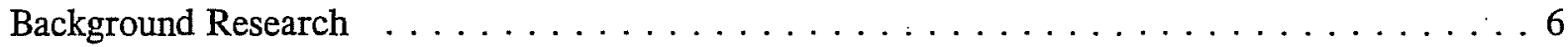

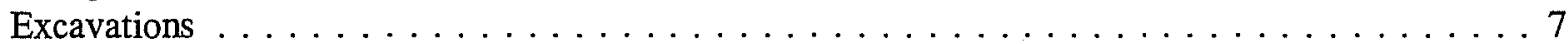

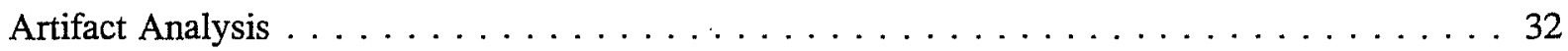

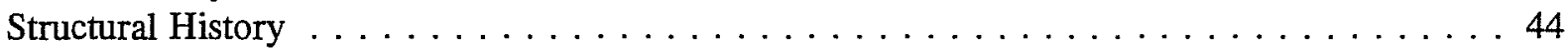

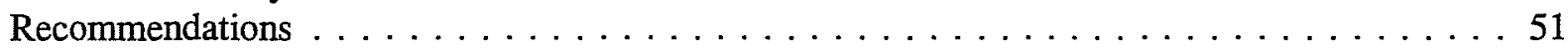

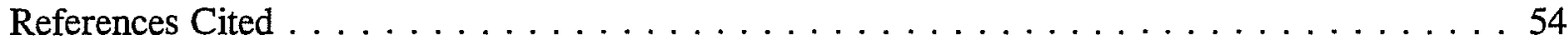

Part III: Mission Parkway Survey

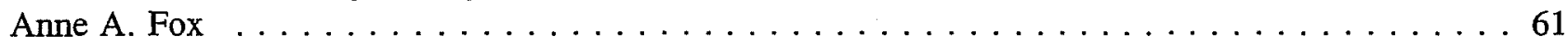

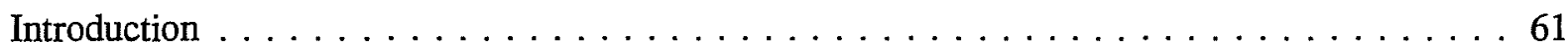

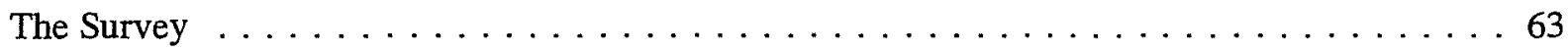

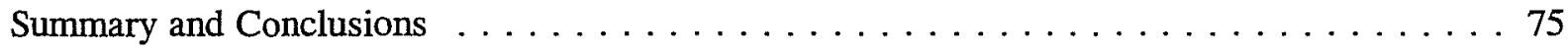

References Cited . . . . . . . . . . . . . . . . . 76

Appendixes

I. Excerpts from the Deed Records . . . . . . . . . . . . . . . . 79

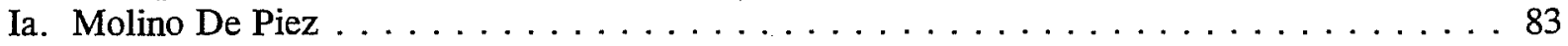

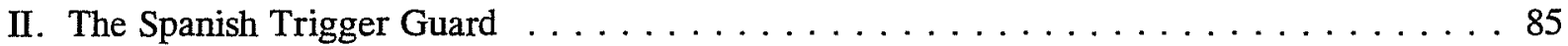

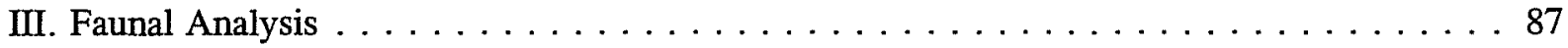

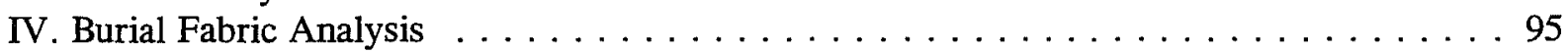

V. Artifact Tables . . . . . . . . . . . . . . . . . . . 97 


\section{Figures}

1. Plan of Mission Concepción Park and Its Immediate Surroundings Today. . . . . . . . . . . . 3

2. Mission Concepción With Its Surrounding Landmarks and Landowners. . . . . . . . . . . . . . 5

3. Outline of Mission Concepción from Deed Records. . . . . . . . . . . . . . . 8

4. Plan of Mission Concepción, showing the locations of excavations and a

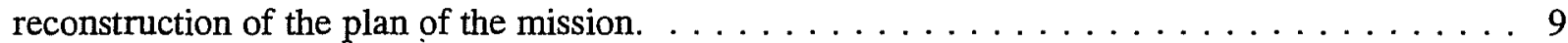

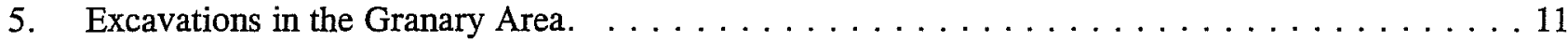

6. Excavations in the granary area, Block $I$, Units $1,3,4$, and $8 . \ldots \ldots \ldots \ldots$

7. Excavations in granary area, Block I, North Profile . . . . . . . . . . . . . . . 13

8. Excavations in east wall area, Blocks $V$ and VII. . . . . . . . . . . . . . . . 14

9. Stratification of Unit 27 in Block VI, East Wall Area. . . . . . . . . . . . . . . . 18

10a. Excavations in the Northeast Corner. Plan of Block VIII, Unit 37. . . . . . . . . . . . 21

10b. Excavations in the Northeast Corner. Plan of Block IX, Unit 36. . . . . . . . . . . . . 22

11. Excavations in the West Wall Area, Block XI. . . . . . . . . . . . . . . . . . 24

12. Excavations in the South Wall Area, Block XII. . . . . . . . . . . . . . . . 26

13. Excavations in the South Wall Area, Block XII, Units 42 and 45 Profiles. . . . . . . . . . . 27

14. Excavations in the South Gate Area. . . . . . . . . . . . . . . . . . 28

15. Excavations in the South Gate Area, Plans of Block XIII, Units 22, 25, and 33. . . . . . . . 29

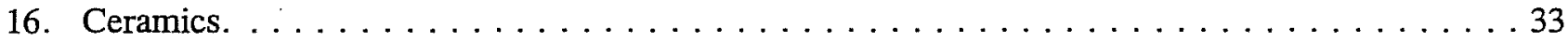

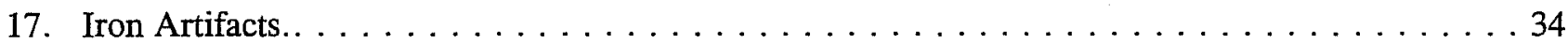

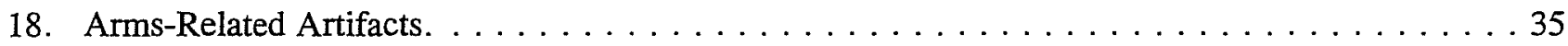

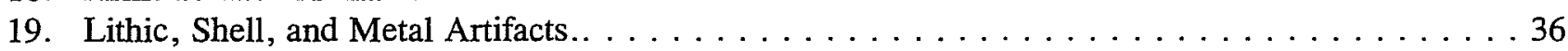

20. Mission Espada Area. . . . . . . . . . . . . . . . . . . . . . . . . . . 64

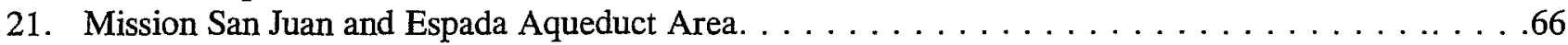

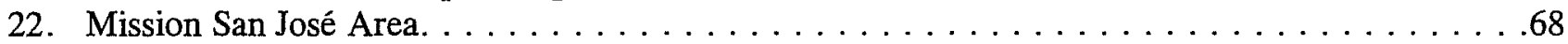

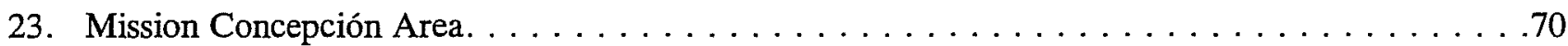

24. Espada Dam Area. . . . . . . . . . . . . . . . . . . . . . . . . . .74 


\section{Tables}

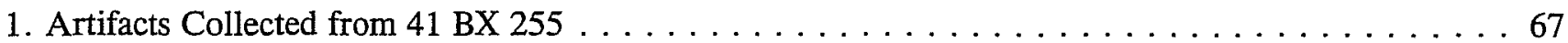

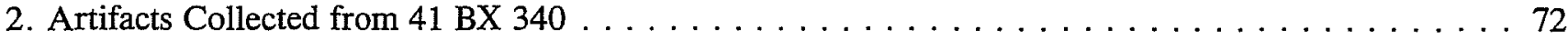

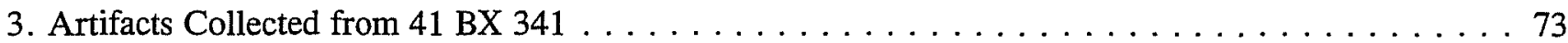

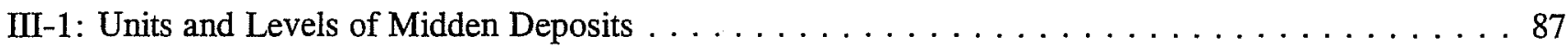

III-2: Distribution of Species in Middens $\ldots \ldots \ldots \ldots \ldots \ldots \ldots \ldots \ldots \ldots \ldots \ldots$

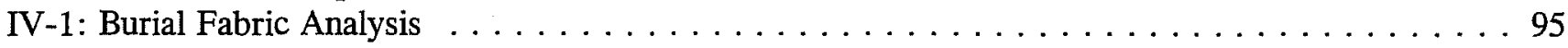

V-1: Artifacts from Granary Area, Blocks I, II, III, and IV. . . . . . . . . . . . . . . 98

V-2: Ceramics from Granary Area, Blocks I, II, III, and IV. . . . . . . . . . . . . . . . . 100

V-3:Artifacts from East Wall Area, Blocks V, VI, and VII . . . . . . . . . . . . . . . . . . . 101

V-4: Ceramics from East Wall Area, Blocks V, VI, and VII . . . . . . . . . . . . . . . . . 105

V-5: Artifacts from Northeast Corner Area, Blocks VIII and IX . . . . . . . . . . . . . . 106

V-6: Ceramics from Northeast Corner Area, Blocks VIII and IX s . . . . . . . . . . . . . . . 107

V-7: Artifacts from West Wall Area, Block IX . . . . . . . . . . . . . . . . . . . . 108

V-8: Ceramics from West Wall Area, Block IX . . . . . . . . . . . . . . . . . . . . . . . . 109

V-9: Artifacts from South Wall Area, Block XII . . . . . . . . . . . . . . . . . . 110

V-10: Ceramics from South Wall Area, Block XII . . . . . . . . . . . . . . . . 111

V-11: Artifacts from South Gate Area, Block XIII . . . . . . . . . . . . . . . . . . . 112

V-12: Ceramics from South Gate Area, Block XIII . . . . . . . . . . . . . . . . . . . . 113

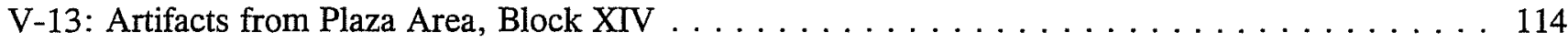

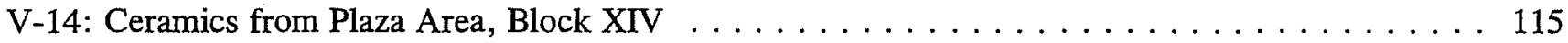




\section{Adknowledgments}

The authors wish to thank many persons for their assistance on this project. During the documents research phase, we were given very capable aid by the research team of Lois Flynn and Waynne Cox. Many of the insights into property use and ownership in this report originated with them.

The excavations were conducted by Lois Flynn, Waynne Cox, Kathy Gonzales, Betty Markey, and Augustine J. Frkuska. Shorter periods of excavation were done by Greg Sundborg, Sylvia Bento, Margaret Mehrtens, and Jim Hickey. Lois Flynn also acted as field recorder, keeping the complexities of log notes, unit notes, artifact bag notes, and so on, under control.

Additional excavation on a volunteer basis was done by Mike Block, Gennesse Thomson, Marlys Thurber, James Escobedo, Debbi Seltzer, Betty Neumann, Lynn Highley, Rebekah Halpern, Darla Cox, Courtenay Jones, Eloise Stripling, Margaret Reasor, Joan Sherwood, Elaine Brown, Jaime Ivey, Jennifer Ivey, and William Ivey. Lab work was conducted by Kathy Gonzales, Elaine Brown, and Sylvia Bento. Typing of the first draft was done by Elaine Brown.

Valuable assistance during research was given by Guadalupe Gonzales, the Bexar County archivist. His efforts to organize the vast quantity of material stored at the county courthouse have been of tremendous aid to us, and we wish to take this opportunity to commend him on his work.

Kim Peel, the assistant registrar at the Witte Museum, deserves thanks for allowing us to examine the various paintings of Mission Concepción in their collections, as does Cecelia Steinfeldt, the senior curator, for letting us look at her photograph and engraving collection.

Thanks also go to Father Brosnan of the Drug Rehabilitation Center for his permission to excavate on church property and his interest in our findings. Pierson Devries, with the Archdiocese, and Max Haney, permanent staff at Mission Concepción, gave us access to the mission grounds and arranged storage space for our equipment. We wish to acknowledge our heartfelt appreciation to Edmond Benavides, the Sacristan of Mission Concepción, to his wife Margaret, and to all the parishioners of the mission who gave us their support and interest.

We appreciate the close support given us by Marlys Thurber, James Escobedo, and many others of the National Park Service during the course of this project. Additional thanks are due James Escobedo for sharing with us the results of his historical research on the missions. Several ideas used in this report originated with him.

Richard Garay shared his memories as a child at St. Peter's and St. Joseph's Orphanage and the results of his research into the past of Mission Concepción. We also appreciate the information and photographs provided by Don Will of Victoria, from his student days at St. John's Seminary in the mid-1950s.

During survey of anomalies and development areas, a number of people were particularly helpful. Special thanks are due to the help and encouragement of archeologist James Bradford and chief of the Division of Archeology Ronald Ice of the Southwest Regional Office, National Park Service. Superintendent Jose Cisneros and staff members Ernest Ortega and James Escobedo of the San Antonio Missions National Historical Park were gracious in providing information and maps for the survey. We are grateful for the aid of Rebecca Cates, Dorian French, and Blair Warren of the San Antonio River Authority (SARA) in obtaining maps of the river and information on channelization and acequia cleaning projects. Jerry Henderson and Marshall Eiserer of the State Department of Highways and Public Transportation kindly shared with us the results of their recent investigations near Mission San José. 
Betty Markey, Katherine Gonzales, and Waynne Cox of the CAR staff helped with the survey, testing operations, and record keeping.

Thomas R. Hester was the Principal Investigator, Jack D. Eaton, the Co-Principal Investigator, and Anne A. Fox served as the Project Director. Fox and Robert J. Hard were Principal Investigators during the final assembly and publication of the report. 


\section{Management Summary}

The Scope of Work for this project called for test excavations to determine, where possible, the boundaries of the mission by locating and defining:

1) the west wall from the quarry to the northwest corner;

2) the exterior walls of the granary and the east compound wall to the northeast corner;

3) selected areas of the north wall and evidence of the Indian quarters on this wall;

4) any evidence of the south wall along Mission Road or immediately adjacent to the quarry.

Parts I and II of the report deal with archaeological testing at the mission. Beginning in December 1980, field work on the project continued for 85 working days. A second round of testing concluded in June 1981 after 88 days of excavation. In the granary area, using information recovered by Harvey P. Smith, Sr., in the 1930s, block excavations located and examined the walls of the original granary and traces of earlier structures beneath them. Moving north of the church, a sequence of foundations and gaps resulting from stone-robbing was recorded in the area where the Indian quarters began to extend to the north. Findings included a large trash pit and a possible section of an early acequia in this area. At the northwest corner of the mission, archaeologists examined and recorded the layout and construction of the Indian quarters where the east wall of the mission turned toward the west along the line of the present driveway of St. John's Seminary.

As the result of considerable mid-twentieth century bulldozing, only patches were found of the mission's west wall foundations. Later work by others farther to the north along this wall has recorded relatively undisturbed foundations which align well with the traces found to the south. Due to extreme bulldozer disturbance at the southwest corner of the mission compound, no structural traces could be found in this area. Part of a ditch-like feature was found, probably an early acequia pre-dating 1731 . The archaeologists were able to conjecturally locate the south wall in this area based on the contents of a trash pit which would have been outside the wall.

In the south gate area, tests were placed outside the ruins of the mission kitchen where the gate was known from archival sources to have been located. A narrow trench-like feature extending northwest from the building's northwest corner appeared to have contained a palisade which probably contained the gate structure. More excavations in this area are badly needed. Also found was evidence of the first adobe church, which ran north-south across and beneath the later kitchen. The evidence included adobe foundations and burials oriented north-south which would have been beneath the church floor.

Tests in the open plaza area in front of the church on both sides of Mission Road, as it was then located, found severe disturbance as well as traces of twentieth century parking areas and flower beds. Testing west of the road indicated that there was no clear sign of mission debris or the original mission occupation surface in that area.

Artifact analysis concentrates primarily on ceramics, which are the most useful tool for dating purposes. Part II of the report concludes with a structural history of the mission based on archival and archaeological evidence.

The following recommendations were made:

1) Further excavations are needed to determine the first plan of the mission.

2) The Mission Road should be relocated outside the line of the west wall.

3) Since nothing appears to remain of the southwest corner, surface delineation should be done.

4) Because of the fragile nature of the Indian quarters walls, they should not be permanently exposed but traced on the surface.

5) The first mission plan might be better explained by a model or plan drawings. 
6) Future work at Concepción should include archaeological tracing of the acequias and possibly location of the grist mill.

Part III of the report describes the results of a survey of specific areas within the San Antonio Missions National Historical Park by Anne A. Fox. This includes identification of numerous anomalies noted on aerial photographs and surface survey of development areas surrounding the missions. Also included is incidental information accumulated by Fox during 15 years of archaeology in and around the missions.

Appendices include excerpts from the deed records which located the outline of the pueblo, analysis of the fabrics from burials, discussion of the Concepción grist mill, faunal analysis by William McClure, and identification of a recovered trigger guard.

Due to various unavoidable complications, the publication of this report has been considerably delayed. The final draft of the report (Ivey and Fox 1982) was compiled immediately after the close of the fieldwork. At the request of the National Park Service, additional illustrations were prepared and added to the manuscript. It then was turned over to the Santa Fe office, where it remained for a number of years in draft form. In response to our request and offer to get it published, the manuscript, illustrations, tables, etc. were returned to the CAR, where it was programmed into the stream of publications turned out on a regular basis by this organization. In the meantime, the draft report has been frequently referenced in other mission excavation reports by CAR authors. 


\section{Part I: Introduction, Setting, and Historical Background James E. Ivey and Anne A. Fox}

\section{Introduction}

On September 17, 1980, the Center for Archaeological Research (CAR) of The University of Texas at San Antonio entered into a contract with the National Park Service (NPS) to determine the original plan of the Mission Concepción (41BX12) compound, or pueblo. This was part of the process of assembling information about the missions to be incorporated into the San Antonio Missions Historical Park and was necessary for proper management and protection of the remains of Mission Concepción. In addition the boundaries of the mission complex were needed to permit effective planning of the relocation of Mission Road along its original alignment west of the mission wall. The contract provided for a period of research into the structural history of the mission in order to determine the general plan of the pueblo from archival collections. This was done to minimize the disturbance of the archaeological record and to maximize the information gained from excavation.

The excavations were to determine the following structural details:

1) location of the four outer walls of the pueblo;

2) evidence of the Indian quarters built against the walls; and

3) the identification of the mission granary and the location of its four walls.

Once the main outline of the pueblo was determined, its corners were to be marked on the ground and plotted on a map of the entire mission complex.
Historical research began in October 1980, and fieldwork commenced in mid-December. The excavations were conducted under Texas Antiquities Permit Number 295. Fieldwork was directed by James E. Ivey, research associate. Supervision was provided by Thomas R. Hester, then CAR director, Jack Eaton, and Anne A. Fox.

Test excavations were laid out using a 50-inch basic unit. This basic unit was multiplied or divided according to the nature of the inquiry in a specific area, but was always given a unit number. In some places, a shallow trench was used to test for architectural remnants; these long, narrow trenches received their own numbers. All units were screened through $1 / 4$-inch hardware cloth. Artifacts from all units were bagged and logged according to provenience, and after washing were labeled with a code indicating this provenience. Logs were also kept of photographs taken, bags filled, and units and strata excavated. All artifacts are curated at the laboratory at CAR.

In May 1981, CAR and the NPS arranged a contract extension to conduct excavations at the projected location of the northeastern corner of the mission pueblo-a process requiring penetration of an asphalt driveway-and to allow additional fieldwork on the line of the south wall, which had been severely disturbed. Fieldwork was completed in June 1981, after 88 days of excavation. The results of all phases of historical and archaeological investigations are presented in Part II of this report.

In conjunction with the excavations at Mission Concepción, CAR was contracted to conduct a 
survey of selected areas within and adjacent to the proposed park boundaries, examining anomalous areas identified by the NPS from aerial photography. This was done to determine if such anomalies were traces of structural or other physical features associated with the missions. This fieldwork was carried out from September 1980 to November 1981 under the direction of Anne A. Fox, research associate. The results of this survey are presented in Part III of this report.

\section{Setting}

\section{Location}

Mission Concepción is located one-half mile east of the present channel of the San Antonio River, four miles south of the center of the city of San Antonio, Texas (Figure 1). In the eighteenth century the natural river channel was approximately $500 \mathrm{ft}$ $(155 \mathrm{~m})$ west of the mission. The mission site is on a knoll or ridge slightly elevated above the surrounding terrain. From the site the land slopes very gradually toward the river to the west.

\section{Soils and Geology}

Soils in the general area are Venus-Frio-Trinity association soils (Taylor et al. 1966). These are grayish brown, alluvial soils which occur in bottomlands and terraces throughout the river valley. The slightly elevated mission site sits on a formation classified by the Soil Conservation Service (Taylor et al. 1966:17) as Hilly Gravelly Land, described as "beds of calcium carbonate consisting of sediments cemented with calcium carbonates" (locally called caliche). On level areas, a mantle of "limy, dark grayish-brown loam or clay loam has formed" (Taylor et al. 1966:17). This is a very accurate description of the conditions found during this and previous archaeology at the site (see Scurlock and Fox 1977:33-37).

\section{Historical Background}

Mission Concepción was originally established in east Texas in 1716. After the cutback of Spanish troops at the military posts in the area in 1729 , some missionaries elected to move their missions to a "more suitable site" (Habig 1968:124).

The missions were temporarily placed on the Colorado River in 1730 and finally moved to the San Antonio River in 1731. From 1731 until 1772, Mission Concepción was maintained by the Franciscan Missionary College of Querétaro. During this time Indians were attracted from surrounding tribes, their instruction in Catholicism and Spanish culture was begun, and the present buildings constructed. In addition to the church and convento (priest's quarters), workshops such as a carpenter's shop, an iron-working shop, a weaving room, and others were built. Quarters to house the Indians were constructed in the form of an enclosed pueblo with a square protective wall and a central plaza. An acequia, an irrigation ditch system, was built to water fields established in the surrounding lands allotted to the mission. A ranch for the raising of cattle, sheep, and other livestock was established on the Cibolo River by 1745 , and an annual mule train supply system-first begun for the Queretaran mission of San Antonio de Valero about 1718-was expanded to bring the necessary finished goods and raw materials required by Concepción and other Queretaran missions from Mexico each year. A similar system supplied Mission San José, operated by the College of Zacatecas.

In 1767, the Jesuit missions of northwestern Mexico were turned over to the College of Querétaro, which subsequently transferred their missions in San Antonio to the College of Zacatecas in 1772 (Habig 1968:136). Beginning in 1780 , the Zacatecans began active planning for the eventual change of the status of the San Antonio missions from reducción to doctrina (Leutenegger 1973:31). This involved the turning over of the management of the "temporalities," the houses, fields, ranches, and worldly goods of the missions, to the pueblo occupants themselves, who then became eligible to pay tithes and taxes to the secular church system (Matson and Fontana 


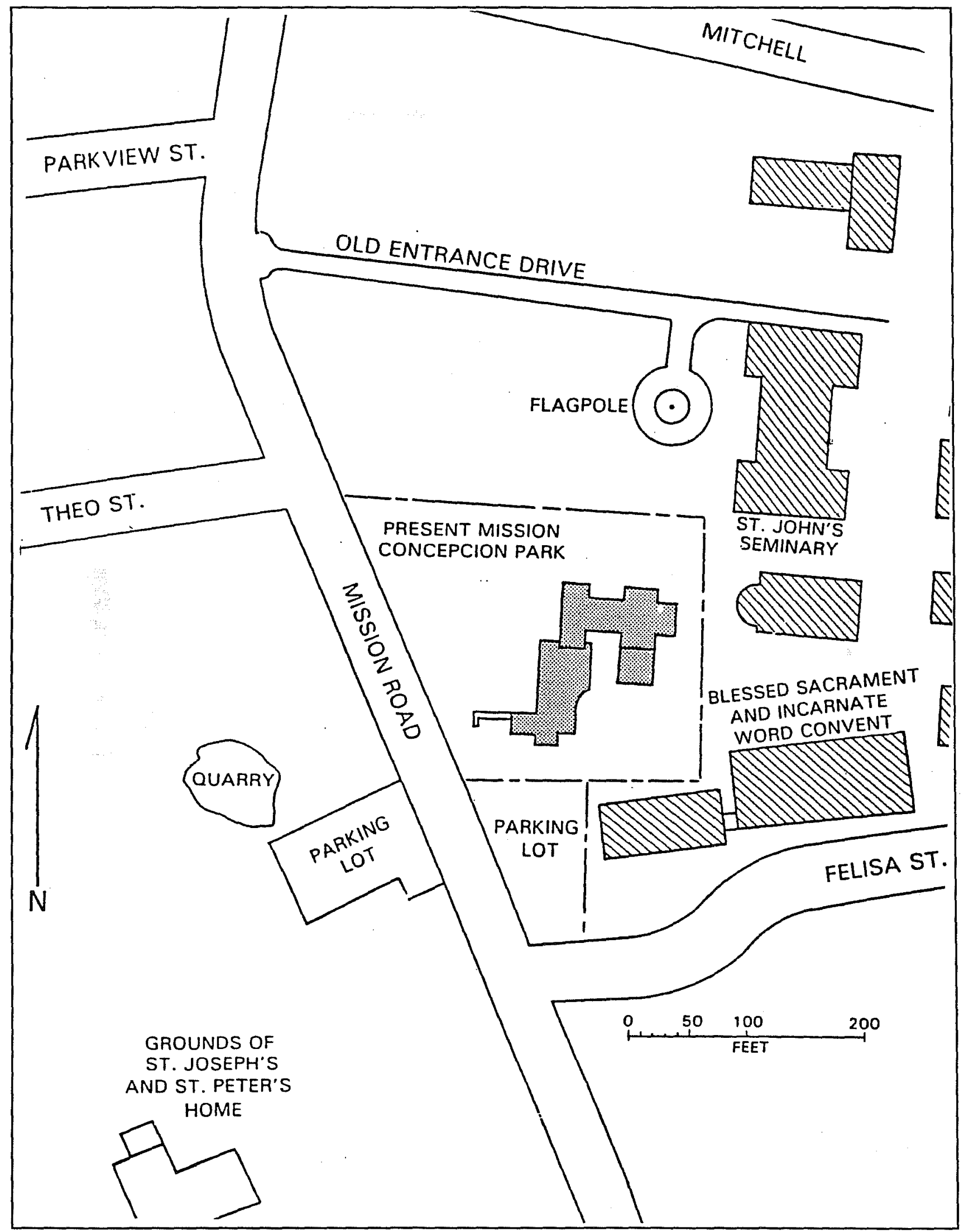

Figure 1. Plan of Mission Concepción Park and its immediate surroundings today. 
$1977: 13-14)$. This step is usually referred to as "partial secularization."

Concepción was partially secularized in 1794 along with the other San Antonio missions, except for San Antonio de Valero, which had been given to the secular clergy in 1793 and discontinued completely as a mission. From 1794 until 1824, Concepción technically continued as a mission administered by the Zacatecans from Mission San José. In 1824, the mission entered its last phase, the curato, or curacy, a fully secular church. The church itself was turned over to the secular clergy of San Antonio; the convento buildings and all other unsold or abandoned houses and land were sold to the general public. The church was effectively abandoned until about 1855 , when the Brothers of Mary began to use those parts of the land of Concepción which still belonged to the Catholic Church. In 1861 the church was reopened for services, and in 1865 the remaining convento buildings were being used for the training of candidates for the Society of Mary (Scurlock and Fox 1977:11).

Further reconstruction and repair led to a rededication of the church in 1887. In 1911 the church and grounds were returned to the bishop of San Antonio. The Works Progress Administration (WPA) sponsored excavations around the standing mission structures in the 1930s. The excavators located a number of sections of wall foundations for structures that had long since disappeared.
In 1971, with increasing interest in the creation of a park which would include all the San Antonio missions, excavations were conducted at Mission Concepción by the Texas Historical Survey Committee, now the Texas Historical Commission (THC). These excavations were designed to:

1) check the condition of the foundations of the standing structures;

2) locate the west wall of the Indian quarters enclosure, or pueblo, in order to reroute Mission Road around the remains of the mission; and

3) increase knowledge of the material culture of the San Antonio missions.

Today, the standing structures of Mission Concepción consist of the functioning church and park operated by the archdiocese. North and east of the present mission grounds are the structures of St. John's Seminary, now a drug rehabilitation center. South of the mission is the Convent of the Sisters of Charity. West of the grounds is Mission Road, and beyond are the grounds of St. Peter's and St. Joseph's Home (Figure 2). 


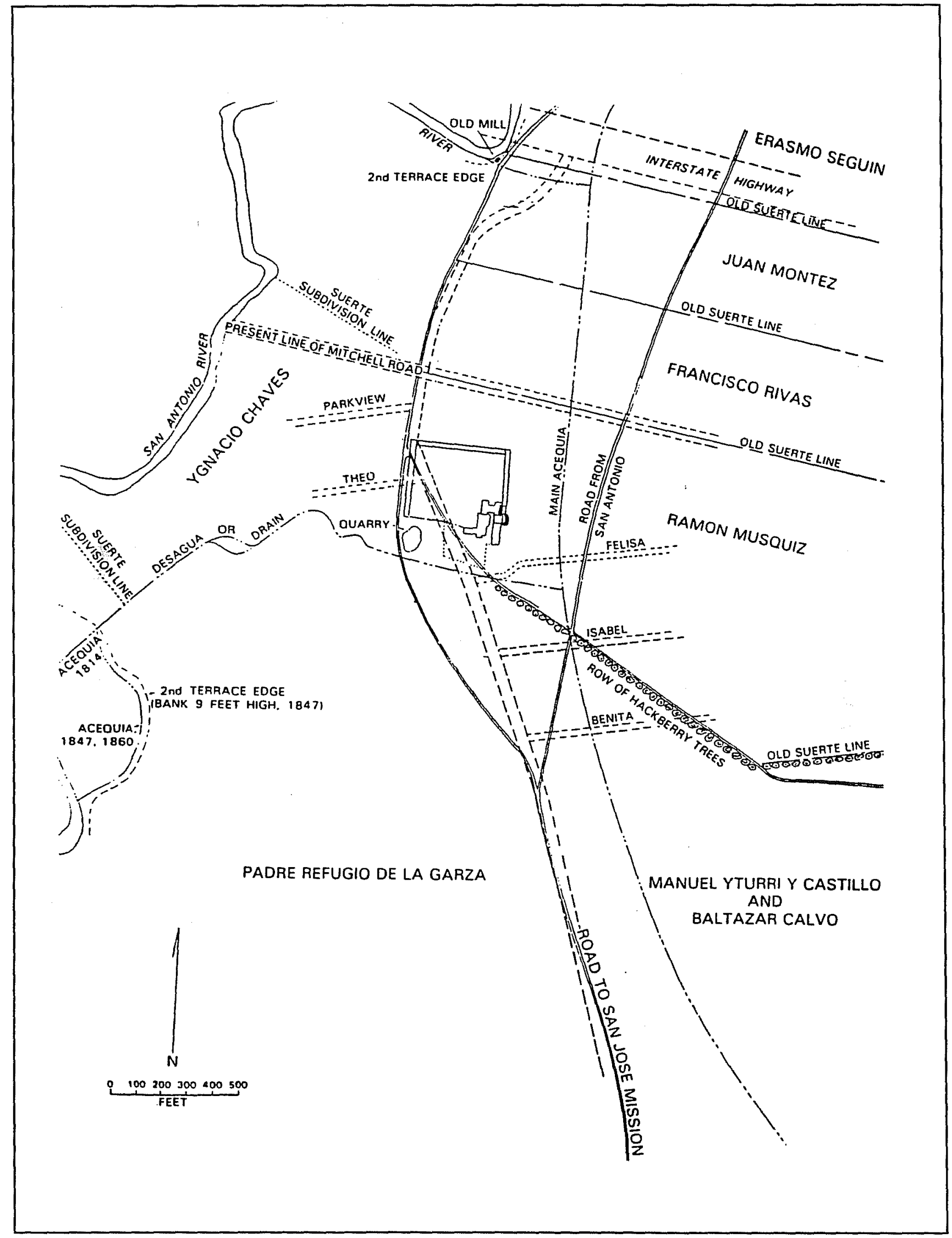

Figure 2. Mission Concepción with its surrounding landmarks and landowners. 


\section{Part II: Excavations at Mission Concepción James E. Ivey}

\section{Background Research}

\section{Previous Investigations}

In 1890 William Corner described the compound walls of Mission Concepción: "the square of the Mission at this date can very hardly be defined, but that the Mission was situated in the south eastern corner of a ramparted square is without doubt" (Corner 1890:17). In the caption on his map of Mission Concepción, Corner adds, "the traces of such walls are today hardly to be defined and their defenses are not shown in the plan for fear of inaccuracy" (Corner 1890:16).

The location of the walls enclosing the mission Indian pueblo has been a topic of debate since Corner declined to hazard a guess as to their position. The best estimates were those of Father Marion Habig (1968:140), the acknowledged authority on the history of the missions of San Antonio, but even he refers to his diagrams as "still only conjectural" (Letter from Marion A. Habig to Curtis D. Tunnell, August 12, 1971. Documents pertaining to excavations at Mission Purisima Concepción. Texas Historical Commission, Austin.).

Excavations conducted for the WPA by restoration architect Harvey P. Smith, Sr., in the early 1930s located a number of wall foundations south of the present church buildings indicating where various mission buildings had stood before falling into ruin, but no traces of the pueblo walls were recognized (Scurlock and Fox 1977:14, Figure 3). In 1971 and 1972, the Texas Historical Survey Committee conducted excavations on the mission grounds in search of the lost walls. Again several fragments of foundation were located (Scurlock and Fox 1977:Figure 3). Later research, however, showed that the wall foundations thought to be a part of the south wall of the mission compound were parts of the same buildings found by Smith in 1934. Only a small section of wall foundation to the west of Mission Road seemed to be part of the pueblo wall.

With the approaching transfer of Mission Concepción to the National Park Service as part of the San Antonio Missions National Historical Park, the location of the actual boundaries of the mission pueblo became very important, since it was considered an absolute necessity to include all of Mission Concepción within the park. The locations of the walls had to be determined so that the lands on which they once stood could be included as part of the park (Figure 2). CAR was assigned to relocate, as precisely as possible, all four walls of the pueblo of Mission Concepción. In the process, investigators were to examine, to a limited extent, the Indian houses built within these walls and to locate the mission granary, also known to have been part of the enclosing structures of the mission.

\section{Documents Research}

Since Habig (1968) had extracted as much as could be gained from available mission records and found that little more than a schematic plan could be assembled from these, it was decided that research into land ownership might produce more 
information. To investigate this area, the deed records of Bexar County and the land-related archival material in the Bexar County Archives (not to be confused with the Bexar Archives, a different collection housed at The University of Texas in Austin) were consulted. The Bexar County Archives is a rich source of historical, cultural, and structural information about the Spanish and Mexican periods of San Antonio. This material had been used on other archaeological problems with great success.

Several maps showing original landowners around Mission Concepción were readily available. The best for our purposes was Giraud's 1874 Map Showing the Names of the Original Claimants to the Irrigable Lands Comprised in the Labores of the Missions Concepción, San José, San Juan, and La Espada, which now hangs in the map room of the San Antonio Conservation Society. Another source for this information is the Historical Map of Old San Antonio de Béxar, compiled by John D. Rullman in 1912; the original is in the map collection at the Center for American History at The University of Texas at Austin.

These maps show the landowners around Mission Concepción as: Ramón Músquiz (on the east), governor of Texas during the Texas Revolution in 1835 and 1836; Manuel Yturri y Castillo and Baltazar Calvo (on the south); Padre Refugio de la Garza (on the southwest); and Ygnacio Chaves (on the west). Bexar County property records were examined for deeds or other documents concerning the land holdings of these people near Mission Concepción. Within a few days four deeds had been found giving explicit locations and dimensions of the east and north walls and describing other buildings associated with the mission. Over a period of several weeks, these and other deeds, some of which are excerpted in Appendix I, were plotted (Figure 3) and a plan of the conjectural outline of the mission compound drawn (Figure 4).

\section{Excavations}

The map of the hypothetical plan of Mission Concepción (Figure 4) was used in placing the first excavation units on the site. It must be kept in mind that the map at this point was conjectural. Good reasons existed for thinking that it reflected the true locations of the various structures expected to be found, but any number of errors could have been made in the interpretation of obscure references in the documents used to compile the map, or in the matching of properties relative to each other from document to document. Placing the quadrangle so the church and convento were on the southeastern corner was contrary to the accepted picture of the mission, even though such a position was supported by Corner's (1890) description. Placing the granary south of and adjoining the sacristy had no documentary support in the mission archival materials; rather, there appeared to be direct statements against such a location. There was no reason, in other words, to be dogmatically confident that the true plan of the mission had been worked out-it was simply the best that could mapped with the information at hand. Archaeological data would have to be compared with the mapped locations of the various structures and confirm or deny the hypotheses.

For that to be effective, the archaeologists had to set up the units so that each area excavated increased our confidence in the remaining structural locations to be tested. Thus they began with the structure most likely to be found: the house of Manuel Yturri y Castillo, which included the granary and was south of and adjoining the sacristy of the mission church.

\section{The Granary Area}

In the 1838 deed from Yturri to Asa Mitchell and in the subsequent 1849 survey made for Mitchell, the Yturri house was described as "three rooms, built of stone, and connected together in a row, which adjoins the said church at its south-east corner" (Bexar County Deed Records [BCDR], Bexar County Courthouse, San Antonio, Texas, A2:74, August 1838; see Appendix I, No. 3b). This house is described in the 1849 survey as "an old house formerly occupied by Yturri," with its west wall oriented $\mathrm{N} 5^{\circ} \mathrm{E}$ and the length of the wall 32 varas $(88.9 \mathrm{ft})$ from the southwest corner of the house "to where said house joins the Concepción Mission" (BCDR Pl:619, March 16, 1849; see Appendix I, No. 4). 


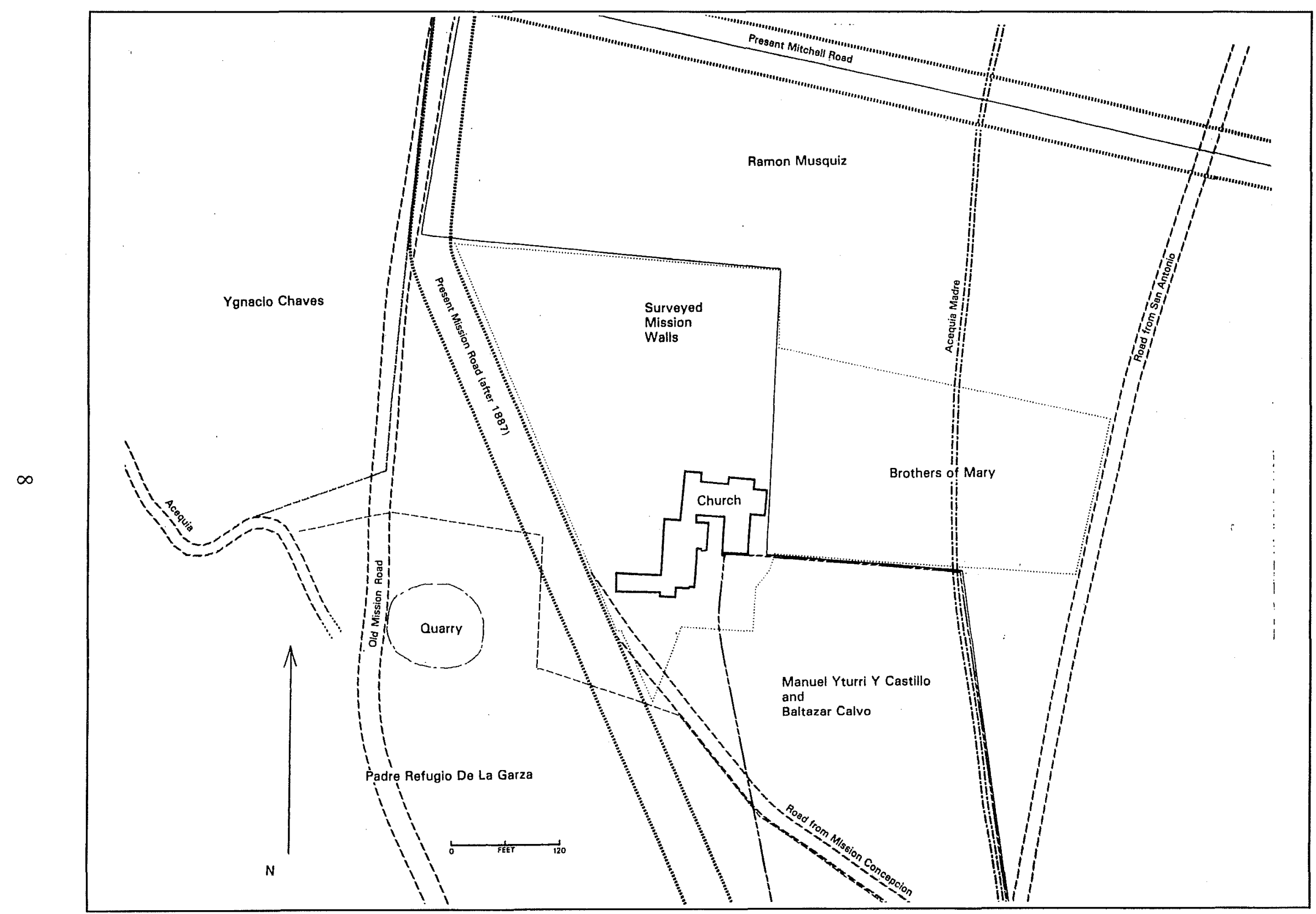

Figure 3. Outline of Mission Concepción from deed records. 


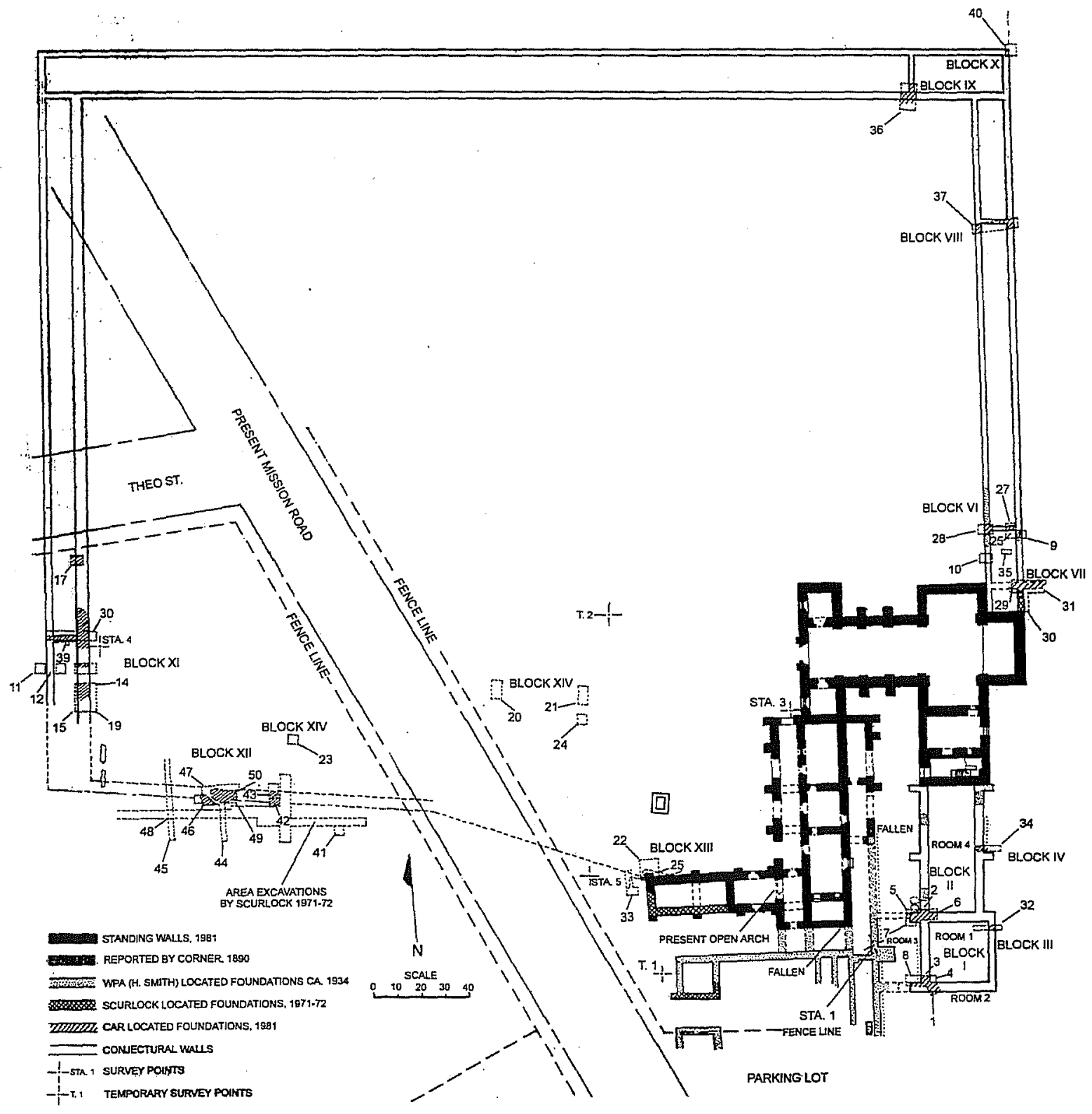

Figure 4. Plan of Mission Concepción, showing the locations of excavations and a reconstruction of the plan of the mission. 
It was known from the WPA map that foundations had been seen in the ground in this area, but their extent was not determined (Figure 5). Our first unit was placed on the approximate position of the south wall of the suspected structure.

Unit 1 almost immediately revealed a massive stone foundation. Obviously, a building had been found, but was it the granary? To be sure that the foundations were those of the granary, a certain set of structural characteristics had to be found in the ground. Sáenz de Gumiel (Inventario de la Misión Purísima Concepción. Roll 10, frames 4235-4263, December 16, 1772, Microfilm Archives, Old Spanish Missions Historical Research Library, Our Lady of the Lake University, San Antonio [OSMHRL]) described the granary in an inventory as being "twenty varas [55.4 $\mathrm{ft}$ ] in length; its width is divided into two bays, and each bay is 5 varas [ $13.85 \mathrm{ft}$ ] wide. It is all of roughly worked stone . . . Outside it is reinforced by six buttresses of stone and mortar." Unfortunately, the priest performing the inventory did not indicate if the dimensions were inside or outside measurements of the building. Obviously if the granary stood here it was only part of this complex, and $33.5 \mathrm{ft}$ of the building was another structure.

The archaeologists were looking for a building with a total inside or outside width of about $27.7 \mathrm{ft}$ and a total inside or outside length of about $55.4 \mathrm{ft}$, made of rough-cut stone, with three buttresses on each side, and thick walls, probably more than one vara (33 inches) in thickness. They assumed that the 55.4-ft granary (with or without the thickness of the walls) would most probably extend either south from the sacristy or north from the south wall of the Yturri house, ending about $33.5 \mathrm{ft}$ from the sacristy. It seemed more likely that the granary would adjoin the sacristy, since the shared wall would reduce the amount of massive wall construction necessary. This presented the problem of working out the outline of the entire building complex and identifying the granary within it, if indeed it was there, by its known characteristics.

\section{Unit Descriptions}

Four blocks of excavations were sufficient to identify the granary (Figure 6). Units 1, 3, 4, and 8 made up
Block I, at the southwestern comer of the Yturri house complex. Units 2, 5, 6, and 7 made up Block II, at the most likely location of the southwest comer of the granary itself. Block III was made up of Unit 32, and Block IV of Unit 34.

Block I was a series of units exposing an area $50 \mathrm{x}$ 150 inches. Unit 1 was a $50-x-50$-inch square at a slight angle to the rest of the block at its southeast corner (Figure 7). It was placed so that the measurement of $88.9 \mathrm{ft}$ from the sacristy's south wall face fell within the southwest corner of the unit. The actual comer location of the expected structure could not be included within the unit because of shrubbery along the chain link fence between the mission's present grounds and that of the Convent of the Sisters of Charity to the south. The orientation of Unit 1 resulted from placing this unit against the fence.

A massive foundation filling most of the unit was soon uncovered. Portions of this foundation were only two to three inches below the surface. A well-defined wall face was found on the south side of the unit, approximately parallel to the south face of the sacristy. The distance from the sacristy to the wall face was $88.4 \mathrm{ft}$, a difference of less than six inches from the 1849 survey. The remaining units of the block were subsequently laid out following the alignment of the foundations.

These showed that the archaeologists had uncovered a foundation made of travertine (a spongy-looking limestone produced by underground water) and a yellow adobe-like mortar. These foundations were about 45 inches thick, the thickness of the walls of the sacristy. To the archaeologists' surprise, they had found not a comer, but a T-intersection, with the eastwest wall continuing towards the convento past its intersection with the wall running south from the sacristy. These walls had formed at least three rooms in this area (Figure 5).

Room 1 was the interior of the Yturri house. It had no clear floor surface, the upper strata within the walls having been badly disturbed. Apparently the floor had been at or near the present ground surface and the clearing of the rubble of the building destroyed it. Distinct evidence of stone robbing was seen in several areas of this block; the sockets where large stones had been removed from the wall were easily identified. 


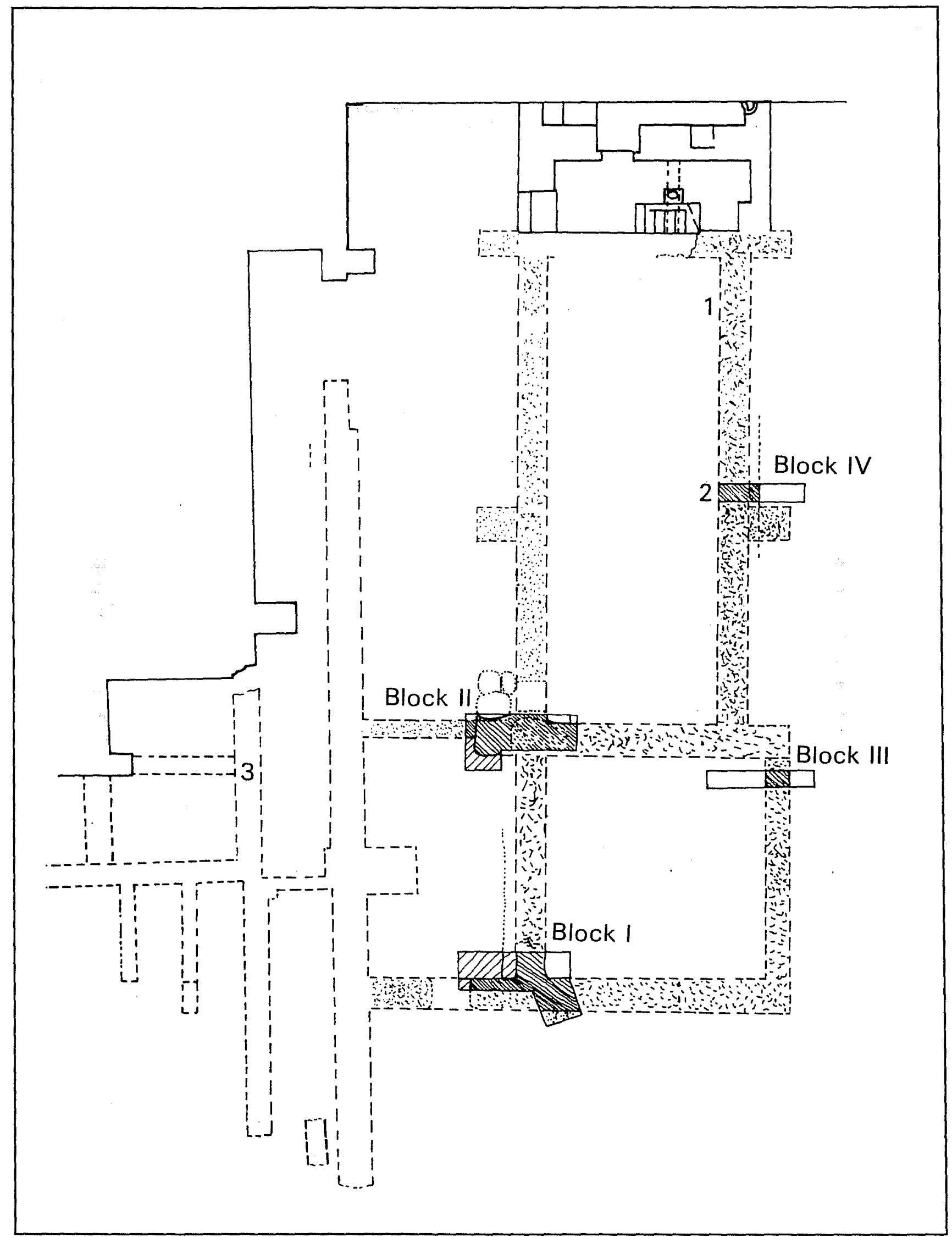

Figure 5. Excavations in the granary area. 1-conjectural granary walls; 2-granary walls located by CAR archaeologists; 3-walls located by Harvey P. Smith, 1930s. 


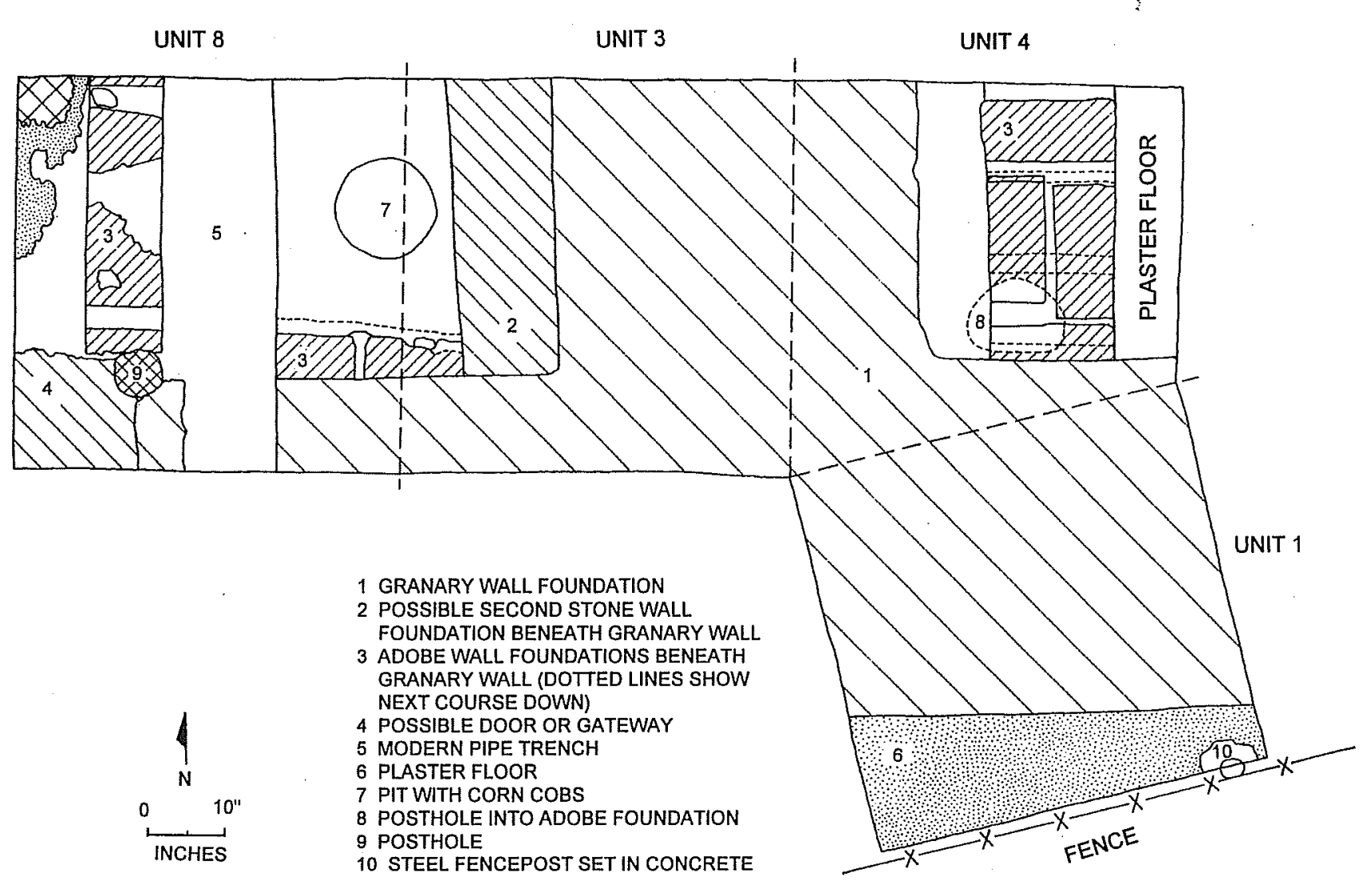

Figure 6. Excavations in the granary area, Block I, Units 1, 3, 4, and 8. 


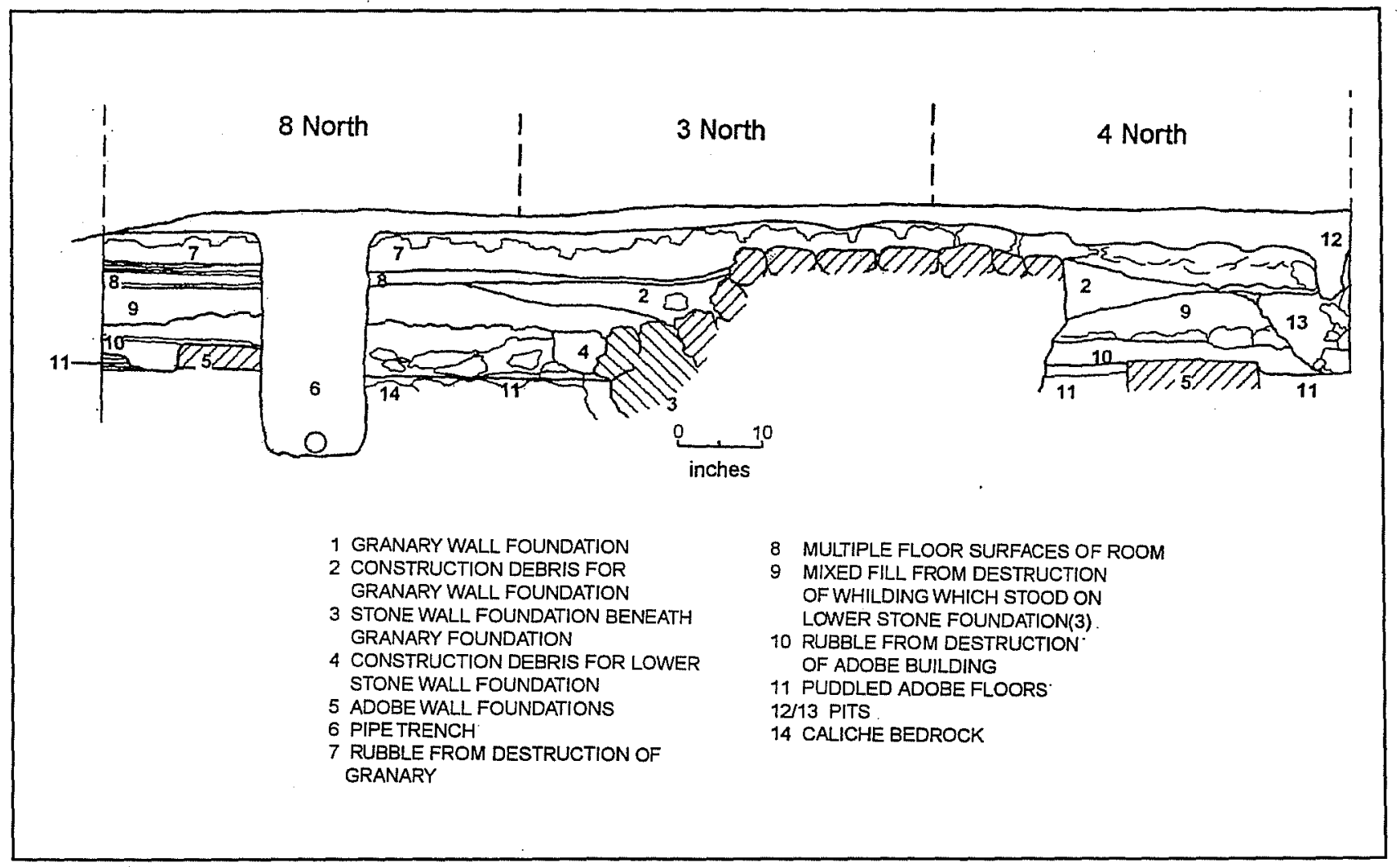

Figure 7. Excavations in the granary area. Block I, north profile.

Room 2 was south of the south wall of the Yturri house, where a hard, white plaster floor was found sloping against the wall face. This made it seem likely that other structures-not necessarily of the same date- continued south from the granary or the Yturri house complex. The plaster floor was 8.5 inches deeper than the floor of Room 3, and associated stratigraphy implies that this plaster floor predates the construction of the walls of Room 1 . Both the east-west wall foundation between Rooms 1 and 2 and the north-south wall foundation between Rooms 1 and 3 show signs of having been built on top of earlier stone foundations (see below, Early Structures in the Granary Area).

Room 3 was formed by the south wall extending west about 55 inches and ending at a doorway. A series of packed earth and adobe floors was found north of this wall, seven inches below the present surface (Figure 8). The floors continued out the doorway. Beneath these floors the wall foundation continued toward the west. This indicates that there was once a room between the convento complex and the granary complex, and that this room had fallen by the 1830 s, since no reference to it occurs in the 1838 description or the 1849 survey. A posthole (Figure 7 , No. 9) may have been part of a door post or gate structure.

Block II was more difficult to interpret, since a large pit had been dug into the area prior to our excavation. This pit was about three feet deep, seven feet wide, and $10 \mathrm{ft}$ long. About half of it was within Block II. The pit had completely removed all archaeological remains from half of Block II and had seriously confused the wall structures and stratification in the block. By removing the fill of this pit and then excavating back into the undisturbed portions of the units, we were able to regain most of the lost structural information.

Excavation of Block II located a cross wall about 45 inches thick with the north face of its foundation $54.5 \mathrm{ft}$ from the south face of the sacristy, $0.9 \mathrm{ft}$ short of the length of the granary as described in 1772 (Figure 5). Extending west from the intersection of the cross wall and the wall running 


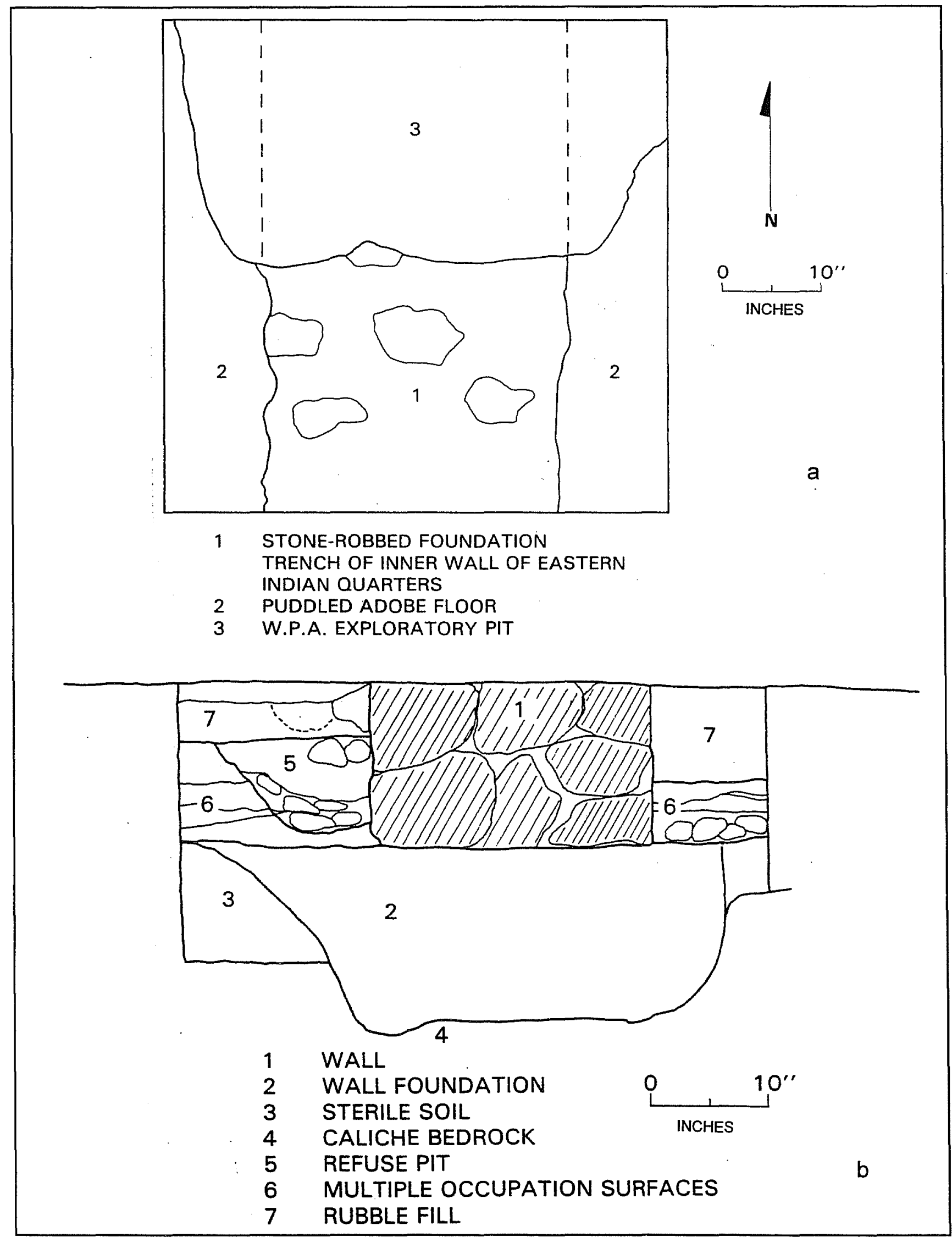

Figure 8. Excavations in east wall area, Blocks V and VII. a. plan of Unit 10, Block V; b. profile of Unit 29 Block VII. 
south from the sacristy was a large masonry rectangle more than 57 inches across, north to south, rather like that encountered later in Block VIII beneath the buttress against the northwestern corner of the "kitchen" (see below, Northeast Corner). This was apparently the base of the southwestern buttress of the granary. Extending west towards the convento from this buttress was another wall, about 26 inches wide, which was probably the north wall of Room 3. The width of 26 inches is rather narrow for a principal wall; it is probable, therefore, that this was a partition wall between Room 3 and another room to the north. Again, several layers of plaster and packed earth floors were found inside Room 3. Disturbance north of the north wall of Room 3 prevented determination whether similar floor surfaces had existed here.

The interior of the granary, Room 4, showed serious disturbance. In addition to the large pit dug into the northwest corner of Room 1, many of the stones had been robbed from the line of the northsouth wall. Fortunately, a small area in the northeast corner of Block II retained its original stratigraphy, and this indicated that the granary at one time had a hard, white, plaster or adobe floor.

A doorway apparently opened through the west wall of the granary in this corner. Outside the west wall and overlapping the footing of the buttress in the northwestern corner of the block was the edge of a large slab of sandstone several inches thick, 32 inches long, and of unknown width. It was worn smooth on the top. This may have formed part of the threshold of an entrance to the granary, or the flagstone floor of a room west of and adjoining the granary. The top of the slab was about two inches higher than the hard plastered surface within the granary.

Based on the information gained from Blocks I and II concerning the plan of the Yturri house and the granary, Blocks III and IV were established to locate the east walls of the structures. Deed records indicated that at least the southern portion of the Yturri house would be approximately $30 \mathrm{ft}$ wide (outside dimension). Block III (Unit 32) was established with a width of 150 inches $(12.5 \mathrm{ft})$ so as to extend over the most likely positions of the east wall of the Yturri house. The wall foundation was immediately below the grass, with less that two inches of topsoil over most of it. The outside dimension of the Yturri house, based on this wall, was $31.8 \mathrm{ft}$ east-west.

Block IV (Unit 34) was intended to locate the east wall of the granary building. Because of the presence of a small restroom building in this area, the block had to stop short of the best position for its west end. The north-south location was intended to find a portion of the central buttress on the east wall of the granary (Figure 5).

Block IV indeed revealed the east wall of the granary and showed that its outside dimension was about $27.1 \mathrm{ft}$. The buttress was not found, but an enlargement in the foundations along the south side of Block IV may indicate that it is just outside the block and to the south.

\section{Early Structures in the Granary Area}

In several areas, traces of buildings were found which predated the standing stone structures of the last Mission Concepción. These traces are probably the foundations of the first permanent phases of construction at Concepción.

Remains of these phases were seen during excavation of Block I, where the bases of adobe walls were found below the stone foundations of the granary (Figures 6 and 7). Two walls crossed the block north to south, and another east to west. In association with these wall foundations were hard-packed, $\tan$ adobe floors. The similarities of depth, material, construction, associated floor surfaces, and stratigraphy all indicate they were part of the same structure, but no points of wall intersection survived within the current area of excavation. The stratigraphy (Figure 7) shows that this adobe building was probably intentionally knocked down, leveled, and the area used as part of the platform on which a stone structure predating rooms south of the granary was built.

The existence of this early stone building was indicated by several anomalies in the foundation of the west wall of the Yturri house in Block I (Figure 7, No. 3). The foundation was found to have an offset, as though the lower portion was not 
precisely on the line needed. More importantly, there were two "surfaces of construction." The lower surface of construction was associated with the offset foundation section, and was the interface between Strata 9 and 10 in Figure 7. From this same surface, just west of the foundation and on the dividing line between Units 3 and 8, a small pit had been excavated, 12 inches in diameter and 8.5 inches deep (Figure 6, No. 7). This pit contained several hundred fragments of charred corn cobs and sticks. Similar pits have been found at other San Antonio missions, usually inside structures near walls. All known examples of these pits have been associated with Indian quarters (e.g. Schuetz 1968:Figure 19).

This evidence is taken to indicate that there was a stone structure built here after the demolition of the adobe building; this stone building was in turn demolished and the foundations partially reused in the late eighteenth century for the construction of the rooms that later became part of the Yturri house. The probability that the early stone structure was part of the first convento of Concepción is discussed in the Structural History of the mission, below.

\section{Summary of Excavations in the Granary Area}

A conjectural plan of the granary and its associated structures is shown in Figure 5. The outside dimensions of the granary measured 9.8 varas $(27.1 \mathrm{ft})$ in width, and 20.7 varas $(57.3 \mathrm{ft})$ in length. Walls were probably one vara $(2.8 \mathrm{ft})$ thick above ground, and the building probably had a hard, white, plaster or adobe floor. The building had six buttresses; one was seen directly, and indirect evidence was found for two others. This indirect evidence was the widening of the foundation at the south edge of Block IV, and the implied location of the southeast corner of the granary indicated by the alignment of the east wall of Room 1.

A second room stood at the south end of the granary. Its dimensions were 9.2 varas $(25.5 \mathrm{ft}$ ) east-west interior and 9.4 varas (26 ft) north-south interior. Walls were all probably one vara in thickness. No indication was seen of the material that may have formed the flooring of this room.
These two structures formed the Yturri house in 1838. The 1838 description "three rooms . . . in a row" (BCDR A2:74) indicates that the granary may have had an added cross-wall running east-west, or that the two-bay north-south division described in 1772 still existed and was merely confused in the 1838 deed description.

West of and adjoining this south room was a third room, $10 \times 6.3$ varas $(27.7 \times 17.5 \mathrm{ft})$, with several sequential adobe and earth-packed floors. This room had fallen by 1838 , since it was not one of the three rooms of the Yturri house. The surveyor stated that he shot the length of the house along its west wall, and excavation showed that the wall he used was that between Rooms 1 and 3 .

Beneath this complex of rooms was seen evidence for two previous phases of construction in the granary area. The first of these were stone foundations reused in part by the room south of the granary; a plaster floor south of Room 1 indicates that this earlier stone structure extended further south. This was probably part of the first stone convento of Concepción; other portions of this convento were found by H. P. Smith to the west of the granary foundations, and were found to be associated with the foundations of an adobe church west of the present convento (see below, "Early Events in the South Gate Area"). Beneath these foundations were the traces of an earlier adobe construction episode which probably date to the period immediately after 1731. Little is known about the buildings of Concepción during these years.

\section{The East Wall Area}

Since excavations in the granary area had confirmed that the conjectural reconstruction of the late-colonial plan of Mission Concepción was correct in its general details, the archaeologists had much greater confidence as they began to place the units designed to find the east wall of the Indian pueblo of the mission. They started near the point where the walls would have joined the north side of the mission church near its east end (Figure 4).

In this area, the 1934 WPA excavations had located a fragment of wall running north-south on an 
alignment with the eastern corner of the north transept. In 1971 the THC found another portion of this wall foundation where it joined the transept, and also found the beginning of a second wall running north from the northeast corner of the apse. CAR research indicated that these two wall fragments were part of the inner and outer walls of the rooms of the pueblo along this side. It was not clear why previous excavators had not realized what they were finding.

\section{Unit Descriptions}

Excavations soon revealed part of the reason for this. Block V of the CAR excavations was placed between where the WPA found a fragment of wall and where the THC had seen their section. Unit 10 of this block found the end of the WPA trench, and running south from it towards the church was an odd disturbance with some traces of adobe or mortar floors on each side (Figure 8a). Obviously, the WPA had run out of wall. The THC field drawings, however, showed the wall reappearing for the last five feet or so before it reached the corner of the transept.

What had happened to the wall in Block V? The CAR archaeologists' conjecture about the wall locations could be wrong; perhaps the earlier excavations whose results they had used as part of their evidence had found pieces of foundation for small buildings built against this side of the church and the actual walls were somewhere else. The CAR archaeologists extended Block VI, originally established over the eastern line of the pueblo walls, to further examine this area, and Block VII to reopen and further extend the area excavated by the THC at the northeast corner of the apse. Block VI was later expanded with a second set of units on the inner wall line of the east side of the pueblo at the northern end of the location given for the WPA wall fragment.

These two blocks slowly revealed what had happened. Unit 27 of Block VII and the eastern section of Block VI showed that the outer pueblo wall, running north from the northeastern corner of the: apse, had been stone robbed. A large trench varying in width from five to seven feet and increasing in depth to as much as $2.25 \mathrm{ft}$ began within inches of the north wall of the apse, and only the lowest layer of foundation stone from the pueblo's outer wall survives in the first six feet of this trench. Beyond that, the trench is empty of all but backfilled earth, occasional rocks, scattered trash, and artifacts ranging in date from the $1760 \mathrm{~s}$ to about 1900 (Figure 9). It became apparent that Block V had also revealed a stone-robbed section of the wall of the pueblo. This had been the inner wall line, but the traces left were insufficient for Smith to identify them as a continuation of the wall fragment he had found (Scurlock and Fox 1977; Figure 3).

Unit 28 of Block VI, on the inner wall of the pueblo, revealed a more complex situation. The WPA trenches which had traced this wall ran across the unit on each side of the wall remains. Stones had been robbed randomly so that across most of the unit only the eastern face of the wall survived. The south half of the unit still had a solid foundation of stone in place. The remainder of the wall across the unit retained a less substantial, shallower foundation. Additionally, the joint between these two sections of wall is square and straight. These features suggest that the wall sections were built at different periods. Perhaps the foundation from the middle of Unit 28 south had been built as part of some previous structure and was reused as part of the pueblo wall because it was in the right place; or perhaps it was built after the rest of the wall.

In excavating the stone-robbers' and WPA trenches in Block I to determine whether there had been two walls where the research indicated there should be, CAR archaeologists located the end of an adobe wall running toward the west from the eastern stone-robbing trench in Unit 27. The western end of this wall was then found in Unit 28 at the edge of the eastern WPA trench. This wall had probably been a partition between two rooms of the pueblo and ran from the outer to the inner pueblo walls. It was probably one of a number of similar adobe or stone cross walls all along the pueblo wall (Figure 4). This wall was peculiar in that several of the "adobe" bricks were not adobe at all, but appeared to be made of lime mortar and gravel, cast or molded into an odd shape. Although these "bricks" were the same general size as the other adobe bricks found in the mission, ca. $9 \times 18 \times 5$ inches, 


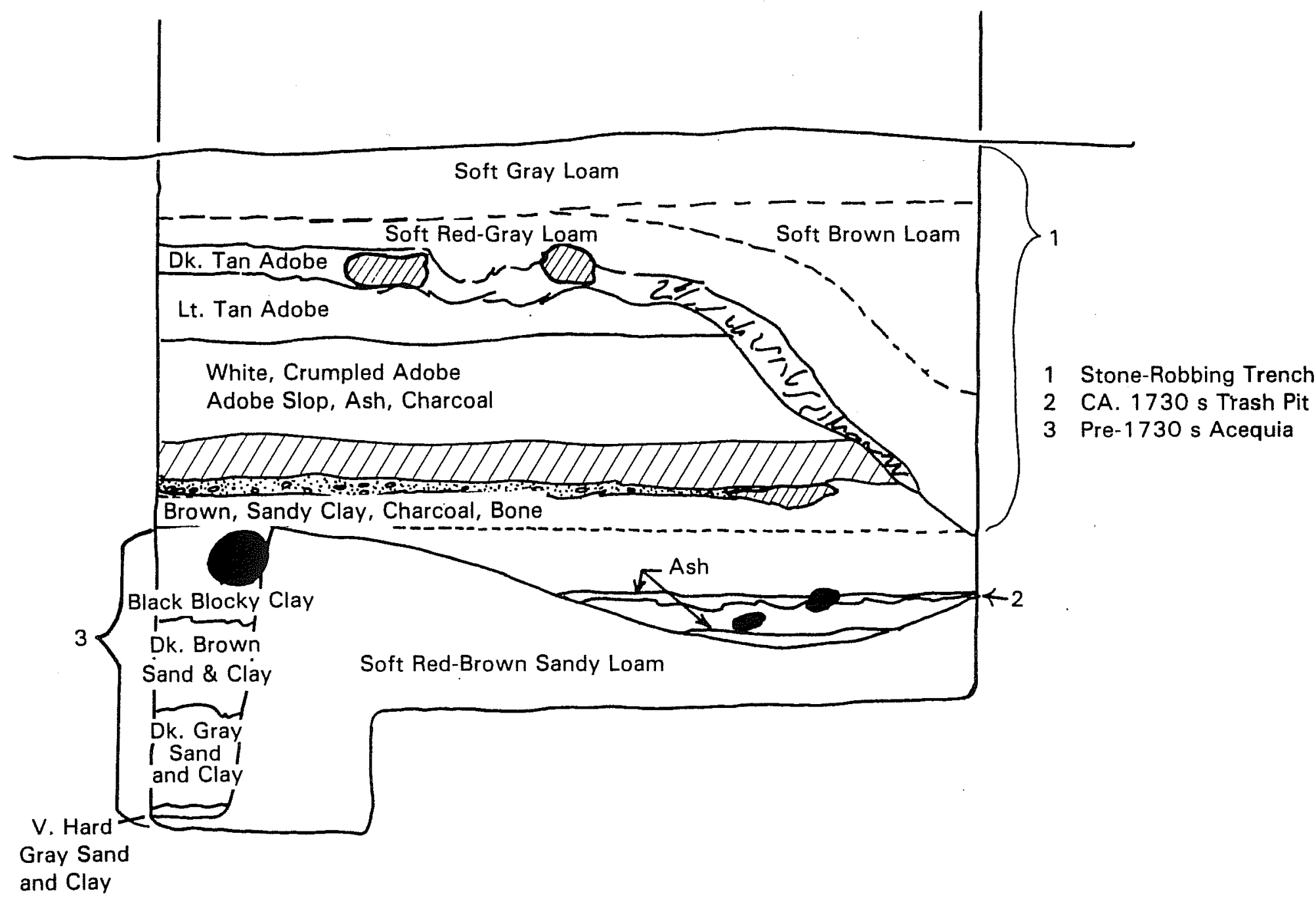

Figure 9. Stratigraphy of Unit 27 in Block VI, east wall area. The early acequia, the overlying trash pit, and the eastern stone-robbing trench are identified." 
they had one long side formed as a rounded convex surface, and the other as a rounded concave surface. It appeared as though they had been formed to be placed together in such a manner that the convex side of one brick would fit into the concave side of an adjoining brick, although they were not assembled this way in the cross wall. Instead they were laid in as any other adobe brick, with no attention paid to their shape. It is suspected that these bricks were not made to be used for wall construction, but for some other purpose, and that those found in the cross wall were reused or surplus. The reason for the shape and the original purpose of these bricks are not readily apparent.

Finding the cross-wall made the archaeologists' conjectural plan of the pueblo in this area a certainty, but they needed to know more. This would require excavations farther to the north where, hopefully, we would leave behind the areas of severe stone robbing and the disturbance of the associated stratigraphy.

\section{Early Events in the East Wall Area}

Beneath the traces of wall construction, stone robbing from these walls, and WPA attempts to locate their remains, we found traces of earlier occupation at the site. A trash pit full of ashes, charcoal, and various artifacts was found in Units 26 and 27 (Figure 9).

The artifacts were typical of those associated with the first few years of mission occupation after 1731. In the trash pit were early majolica, locally made unglazed ceramics, and bones. In the upper layers of the pit fill were two items associated with firearms. One of these was an ornate trigger guard with the face of one of the four winds (frequently seen drawn on the corners of old maps) carved onto its surface (see Artifact Analysis section and Appendix II). The other was a "worm," a small device used to pull a lead ball out of a musket barrel when the powder charge failed to fire (see Artifact Analysis section).

This material had been dumped layer by layer over time into a trash pit intentionally excavated for this purpose. It was a circular, bowl-shaped hole about five feet across. It is usual for such pits to have been dug outside the walls of a mission, near a gate. The presence of the pit therefore suggests that a wall enclosing the pueblo or convento was near this location at the time the pit was being filled. The early adobe and stone foundations seen in Blocks I and II reveal that the main group of early structures at the mission was south of Blocks V-VII, so the north wall of the pueblo described in 1745 was probably just south of this pit in Block VI. This wall may have been found in Block VII, discussed below.

Below this trash pit, a large ditch-like feature was found running across the block north to south. It was filled with multiple layers of sand, gravel, clay, and a large mass of bones in the upper layers. Most of the bones were bovid and could be either cow or buffalo (see the faunal analysis of this material in Appendix III). A great number of unglazed, locally made potsherds were mixed with the bones. All evidence indicates that this was a man-made ditch. It has flat, almost vertical sides and a fairly level bottom, and resembles an acequia, or irrigation ditch. The multiple layers of clay and sand which filled most of it indicates that it was probably abandoned or neglected for a time. The bones and potsherds in the upper layers of this fill show that it was used as a trash dump after this period of neglect, and the almost complete lack of any European materials tells us that the trash was produced by a non-European group. The only indication of Spanish occupation in the area was a large glob of lead and a fragment of Colonial brick found among the bones. The date of this material must be quite early; since the trash pit containing material dating from 1731 to 1745 overlies the ditch and cuts through it in places.

In Block VII, a foundation extended eastward across the line of the east pueblo wall. The stone robbing episodes had removed all traces of the east pueblo wall in this area and portions of the eastwest wall and had destroyed the evidence of which wall was built first. The only chronological marker was one piece of Puebla Polychrome majolica, found in an undisturbed context in the footing trench of this wall (see Artifact Analysis section). Based on this sherd, the wall may date to the 1731-1745 period of the first pueblo. This implies that the wall foundation could have been built as part of the first pueblo defensive wall. It should be 
noted, however, that a single sherd does not constitute good chronological evidence.

The wall foundation itself is unlike that of the other foundations at the site. The stone structures tend to have foundations of travertine chunks with an adobe matrix placed in deep, flat-bottomed footing trenches dug into the ground for the heavier walls (one vara or more thick). The lighter walls (less than one vara thick), both adobe and stone, are usually constructed either directly on the natural ground surface or into very shallow footing trenches. The wall in Unit 29 of Block VII was built on a foundation of yellow sand, gravel, river cobbles, and perhaps some lime poured into a broad, round-bottomed trench (Figure $8 \mathrm{~b}$ ). The wall itself was of large, roughly trimmed limestone chunks.

\section{The Northeast Corner}

Blocks VIII (Unit 37), IX (Unit 36), and X (Unit 40) were located on the projected pueblo wall positions based on the 1860 deed records and the results of excavations at the northeast corner of the church. It was hoped that the stone robbing which had destroyed so much of the eastern pueblo wall near the church had not extended too far north and that clear foundation remains could be found in the northwestern corner.

In this area the construction of St. John's Seminary and its associated landscaping resulted in the accumulation of two to three feet of overburden along the wall lines. After the removal of this disturbed material in Blocks VIII and IX, the foundations of the east and north walls of the pueblo were located quite close to their expected positions.

The structure of the Indian quarters inside the pueblo was clearly delineated in Block VIII (Figure 10a). The outer east wall foundation was stone and 29 inches (a little less than one vara) wide. An adobe partition like that found in Block VI ran from the outer wall to the inner one. The inner wall was well defined on its eastern face but had no clear western face. It seemed to merge into a pavement-like area of adobe and travertine cobbles. Because of this no precise width of the inner wall could be obtained in this block; but the remains of the inner wall as seen in Blocks $\mathrm{V}$ and VI were a consistent 28-30 inches. The purpose of the pavement-like surface is unknown.

The floor surface of the room south of the partition was irregular and showed evidence of several resurfacings with clay or adobe. A badly worn Carlos III silver coin dated 1788 was found in a hearth feature associated with one of the upper floors. The artifacts from the jumble of living surfaces all date post-1750. The eastern stone wall was built into a shallow trench, while the adobe partition wall was built directly onto the original ground surface.

Unit 36 of Block IX contained a virtually identical set of structures (Figure 10b). The presence of a paved driveway on the line of the outside north wall prevented our digging a complete cross section across the north line of rooms as was done in Block VIII. The room divider on this north side was stone rather than adobe, and hearth features were found in the corners of both rooms created by this partition.

As in Block VIII, the inner wall blended into an apron or pavement of travertine and adobe built against the inner wall of the houses. A crosssection trench was cut across the apron and the shallow footing trench for the inner wall was found. This was less than three inches deep and was 29 inches wide, as was expected from the evidence seen in Blocks V and VI. The same pattern of inner wall associated with an apron-like pavement was also found on the west wall, discussed below.

Block X was established to locate the northeastern corner precisely. This was one of the excavations carried out as part of the contract extension discussed in the introduction. A square hole was cut through the asphalt pavement of the drive of the old seminary centering on the point where the corner should be, based on the conjectured intersection of the actual line of the ease outer wall and the most probable location of the north wall. 


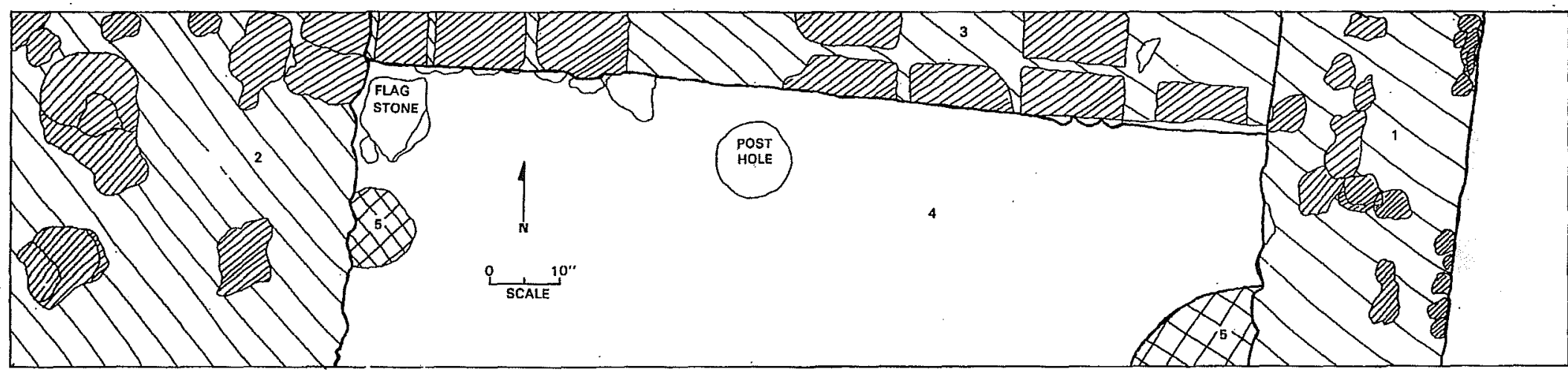

EAST WALL FOUNDATION OF INDIAN PUEQLO

OF MISSION CONCEPCION

ADOBE DIVIDING WALL
INDIAN QUARTERS ROOM

FIRE HEARTH

Figure 10a. Excavations in the northeast corner. Plan of Block VIII, Unit 37. 


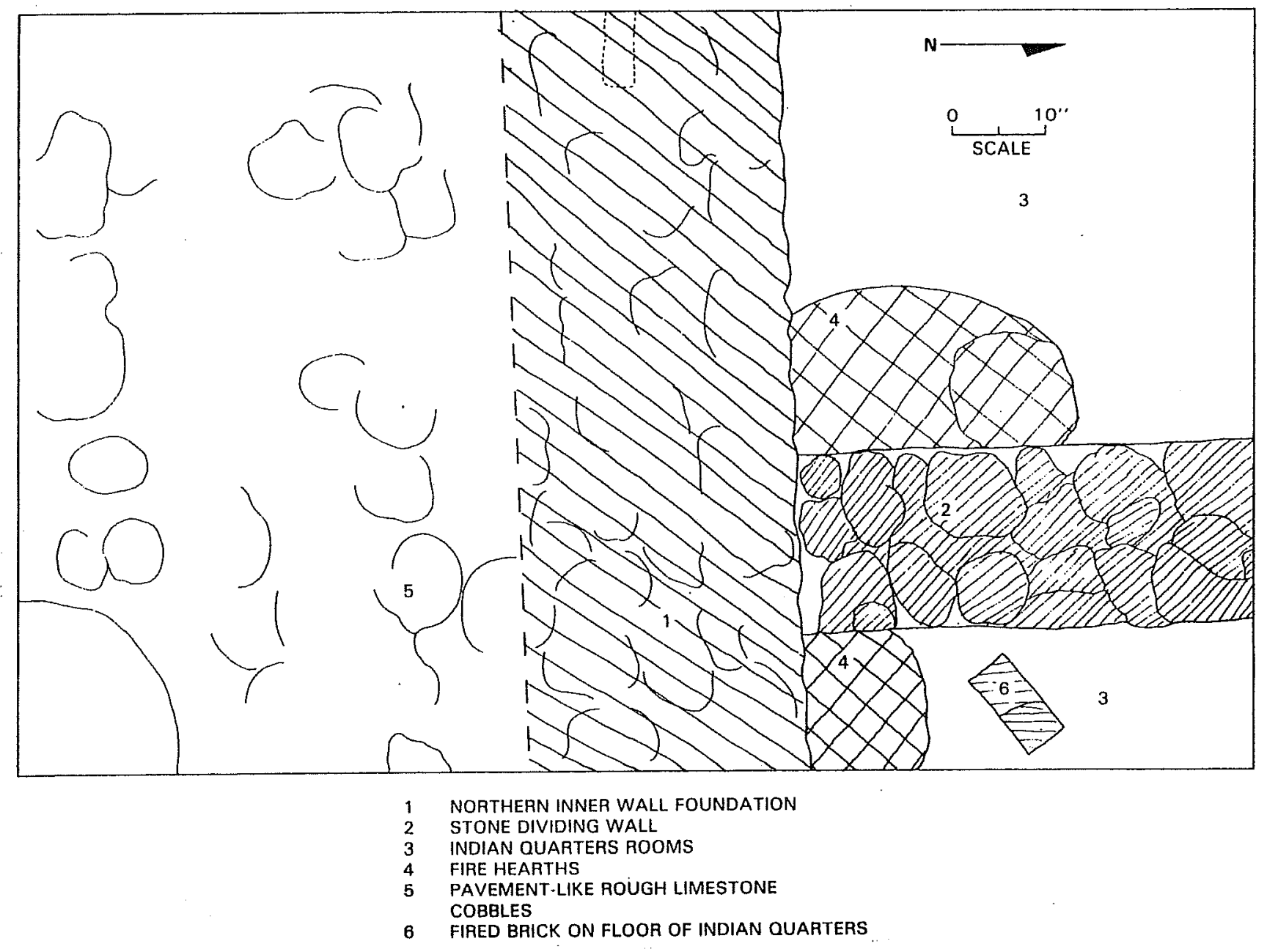

Figure 10b. Excavations in the northeast corner. Plan of Block IX, Unit 36. 
This block located the corner, offset approximately seven inches to the west of our most probable position. A considerable deposit of mission-period trash was found against the wall at this corner, but apparently not in a formal trash pit. The excavation was taken into this deposit deep enough (about four inches) to definitely outline the foundations.

An odd aspect of this block was that the corner itself was well defined but that a fairly clear line of foundation appeared to continue to the north, with a butt-joint between it and the corner of the mission pueblo. Apparently, after the construction of the pueblo wall, a structure was built onto the north side of the northeastern corner. There is no such structure in the historical record, but such an action would not be surprising. At San Antonio de Valero, for example, at least one mission-associated building is known to have been outside the walls near the southwestern corner (Ivey et al. 1990:330).

\section{The West Wall}

The deed records had proven to be dependable for locating the old pueblo walls. Using our known position of the northeast corner, we re-shot the survey lines across modern Mission Road, marked the probable location of the northwest corner on the pavement, and laid out the line of the west wall south into the open fields north of St. Peter's and St. Joseph's Home. Here we set up a series of units (11-19, 38-39) forming Block XI (Figure 11).

These units revealed that there had been extensive removal of earth in the area of the west wall. In most areas there was only a one- to three-inch-thick layer of thinly scattered recent artifacts mixed with a few colonial and Indian items. No undisturbed colonial occupation strata were seen. In a very few places along the west wall, the deeper portions of a few colonial features were found intact.

Subsequent excavations (Fox 1992; Brown et al. 1993) have shown that the areas of stone rubble traced by these units were not wall foundations, but probably linear features left on the limestone gravel as a result of bulldozing of the entire area in the 1950 s or $1960 \mathrm{~s}$. The actual alignment of the west wall as found by Fox connects the probable northwest corner with the segment of wall found by Scurlock.

The west wall itself and its associated rooms survived only in patches. In Units $13,14,16,18$, and 38 the broad inner apron or pavement seen in Blocks VIII and IX survived, although it stops in an irregular line across Unit 16. Traces of the adobe mixed with the travertine cobbles continue into Unit 15, where it too disappears. One well-defined partition wall was followed in Unit 38, but at the point where it should have met the outer west wall the stone traces fade into scattered rubble. No trace of the outer wall was found in this block. The last traces of burned clay beneath a hearth or other small fire were found inside the inner wall line in Units 14 and 19.

Local informants tell us that the entire southwestern corner area had been scraped repeatedly by bulldozers during the late 1950 s or early 1960 s by Father Manning, one of the priests who operated the orphanage. He leveled the various mounds and ridges in the area and filled the old acequia that ran across this section of the orphanage grounds. This scraping removed almost all traces of the pueblo walls in this area. Those that survive are generally within two to four inches of the surface and are the bottommost two to three inches of the wall foundations. In many places the scraping completely removed all traces of the walls. The wall rubble itself left a thinly scattered layer across the surviving wall fragments, making them even more difficult to recognize. Fortunately, the deed record surveys gave us a fairly good idea of the location of these walls; our experience with the wall remains in the northeast corner allowed us to recognize the surviving traces. The worst problem was that there was no way to know where traces of the west wall may have survived the bulldozing. This made the placing of units more difficult.

\section{The South Wall}

The problems encountered along the west wall were repeated along the south wall. Documentary research indicated that most of the south wall may never have had Indian quarters built along it (see below, The Structural History of Mission Concepción), except in the southwest corner itself. 


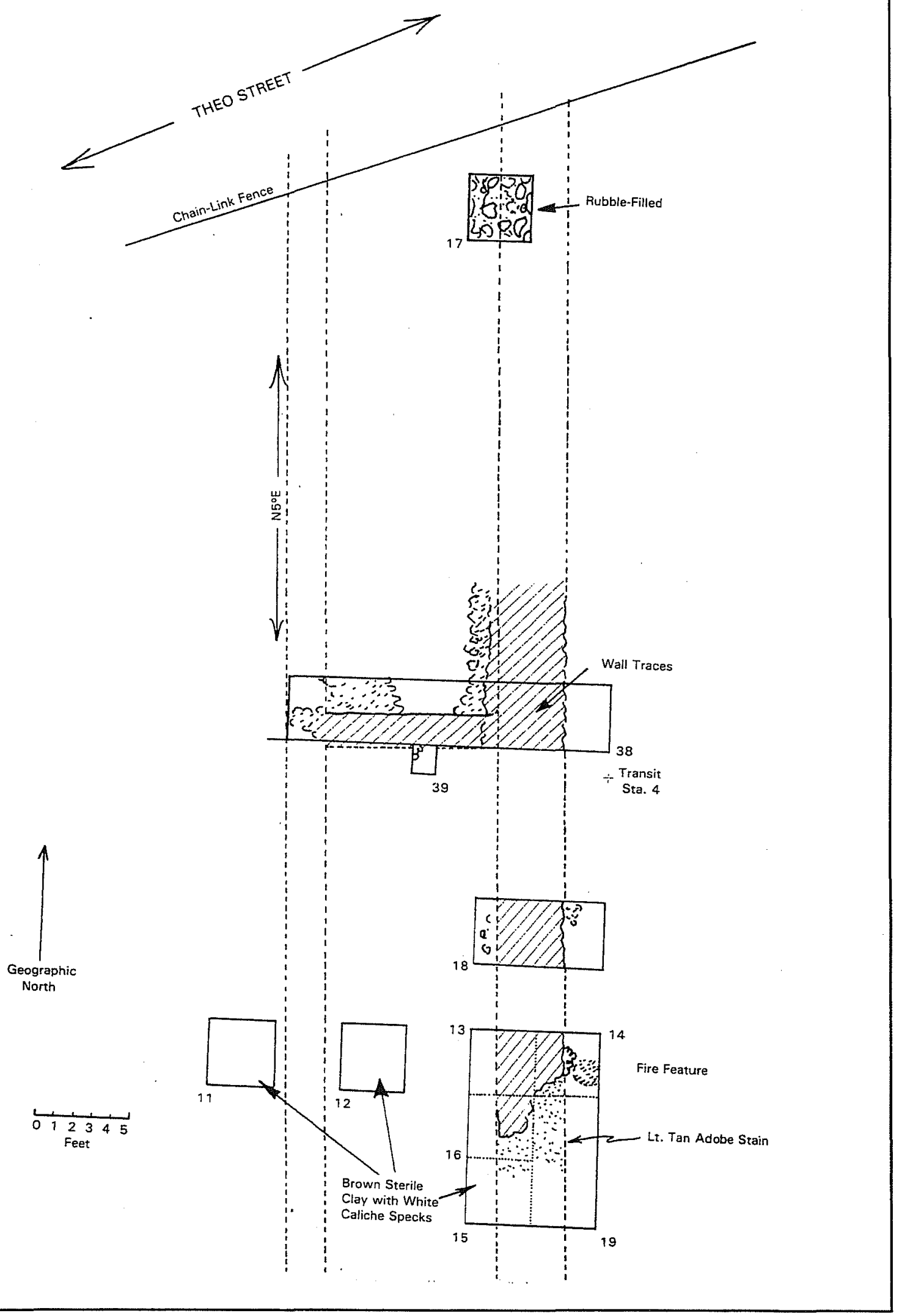

Figure 11. Excavations in the west wall area, Block XI. 
The bulldozer damage seemed to be most pronounced in this area, and no traces of structures were found by shovel testing and probing.

\section{Unit Descriptions}

Block XII, consisting of Units 41-50, explored this area; no unambiguous traces of the south wall were found (Figure 12). In Units 42, 43, 44, 47, and 49, portions of pavement-like travertine and adobe were seen. In Units 42,43 , and 49 , fairly welldefined straight edges were noted. This may be the line of the inner or outer wall (Figure 3). Much more extensive excavation in this area would be necessary to prove this.

\section{Early Events in the South Wall Area}

Beneath the travertine and adobe pavement in Unit 42 , a portion of a ditch-like feature was found. Its lowest levels had fine sand, gravel, and clay strata typical of ditches containing flowing water (Figure 13a). No explicitly man-made characteristics of this ditch were seen, indicating that it might be a natural watercourse rather than part of an irrigation system; nevertheless, the possibility remains that this was part of an acequia system through this area.

[Note: Subsequent excavations in this area were carried out by the author as part of a follow-up National Park Service investigation in the summer of 1982 (Ivey 1982). During these excavations, the THC units dug in 1971-1972 were cleaned out, and a clear profile of the east face of the units was drawn. These investigations add considerable support to the supposition that this was a man-made irrigation ditch dug in the area in the 1720 s. They also indicate that the ditch made a sharp bend from an east-west orientation to a much more southerly heading at this point.]

This probable acequia, like the probable acequia in Block VI, was filled with several strata of sediment overlaid with colonial trash deposits. The datable material found in this midden (including ceramics datable to the first quarter of the eighteenth century) indicates that it was filled about 1720-1730. The fill indicates the following sequence of events: the acequia was excavated and used for a time; then cleaning of the ditch stopped, and after a period of no maintenance, trash began to be dumped into the ditch. The datable artifacts in the trash indicate a date in the 1720 s for this dump, which means that the excavation, use and abandonment of the acequia had to occur in the early 1720s. The date estimate is based on a comparison of the artifacts from Unit 42 with artifacts from an acequia filled in ca. 1725 at San Antonio de Valero (Fox and Ivey 1997). In the Structural History section below, it is suggested that this acequia dates from the first occupation of this site by Mission San José. It is, of course, possible that the acequia in the area of Unit 42 was dug in 1731 and filled soon after, but at present the suggested date of pre-1731 is preferred. After the acequia was filled, the pavement-like surface apparently associated with the late-colonial compound wall of Concepción was built across the ditch line between 1756 and 1759.

In Unit 45, one edge of a steep-sided pit was found, dug into the solid caliche subsoil (Figure 13b). This pit had three major strata of fill. The lowest was a butchering midden deposit consisting mostly of animal bone. Many of these were still articulated, indicating that the pit fill had not been disturbed since it was deposited. Above this was a 12-inch layer composed almost entirely of fragments of mortar and wall plaster. Some chunks were nearly two inches thick and had flat surfaces overlaid with layers of whitewash. These must be the result of the demolition and clearing of nearby buildings surfaced with this material. The buildings were most likely jacal or adobe, because very few fragments of limestone or travertine larger than one inch across were found in the deposition. Over this building rubble was a multilayered midden deposit filling the pit to the point where the scrape zone cuts across the area. The datable artifacts in this midden are from about 1760-1780. The midden is typical of those found just outside the walls of the missions and similar to the pit found in Block VI, above. The presence of the midden fill in the pit argues that the south wall of the pueblo was nearby, and the known location of the pueblo itself indicates that the south wall was probably to the north. In other words, the evidence given by the upper layer of this trash pit supports the conjectural location of the south wall of the pueblo. 

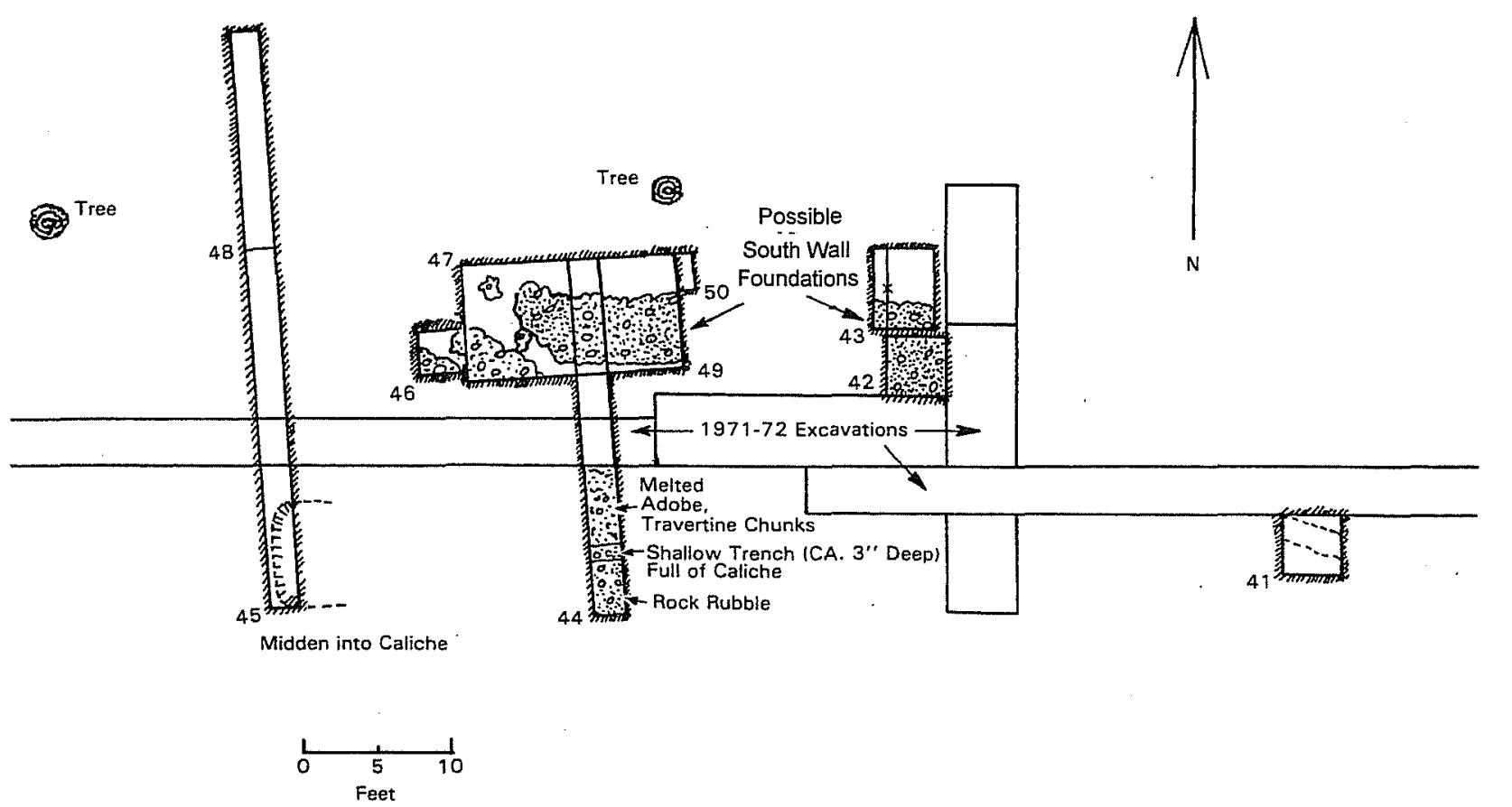

Figure 12. Excavations in the south wall area, Block XII.

It is considered likely that the stratum of broken mortar slabs and chunks in the pit dates from ca. 1765 , even though no datable artifacts were seen. This rubble was probably a product of the destruction of the jacal pueblo of Concepción, which apparently took place ca. 1765 . The 1762 report indicated that a fair number of jacales still stood in that year, while the 1772 inventory reported that all Indian quarters were of stone. This indicates that the strata below the building rubble date from before 1765 . It is likely that the pit was excavates as a trash pit about the time the jacales were torn down, ca. 1760-1765.

\section{The South Gate Area}

Several units forming Block XIII were placed at the western end of the ruins of the probable kitchen room of the convento complex (Figure 14) in search of the remains of the south wall where it should have closed off the pueblo square. Previous excavation in and around these ruins by the THC in 1971 and 1972 had revealed that the foundations of the south wall of the kitchen were still present in the ground, although few traces were visible above ground. The conjectural plan of the mission based on the document research indicated that one alternative arrangement of the walls would result in the south wall extending eastward to the northwestern corner of the kitchen structure.

\section{Unit Descriptions}

Units 22 and 25 were established at the northwest corner of the ruins. They quickly revealed the massive foundations of the kitchen building and a complex of postholes, probably for fence posts. No traces of wall extending northward from the northwest corner of the kitchen ruins were found. At the actual northwest corner itself, a ditch-like feature extended northwestward from Unit 25 (No. 8 in Figure 15b). This feature looked like a palisade trench-a deep, narrow trench excavated to support a row of posts or poles for a building wall or as a defensive wall. Very little of this 


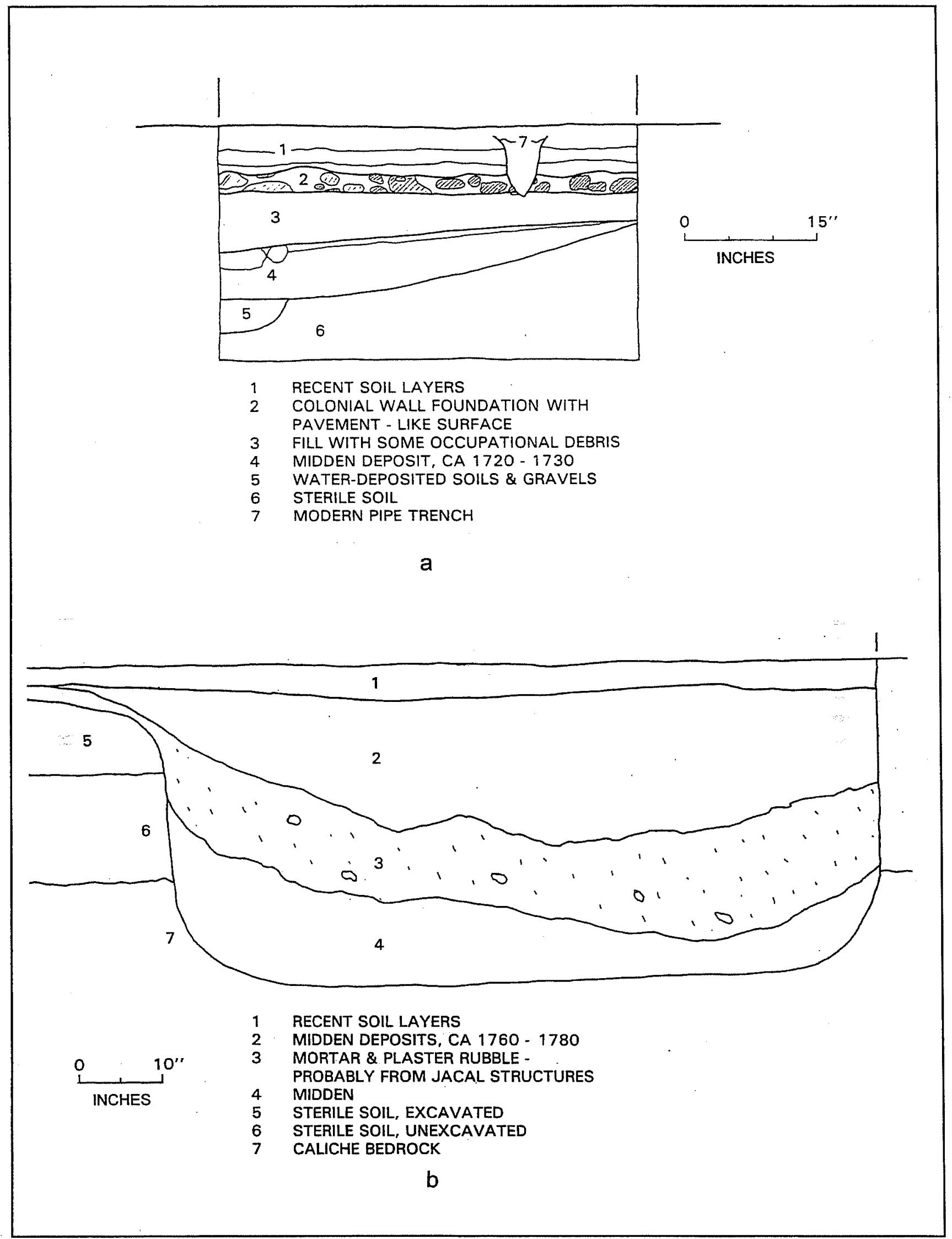

Figure 13. Excavations in the south wall area. a. profile of Block XII, Unit 42 ; b. profile of Block VII, Unit 45. 


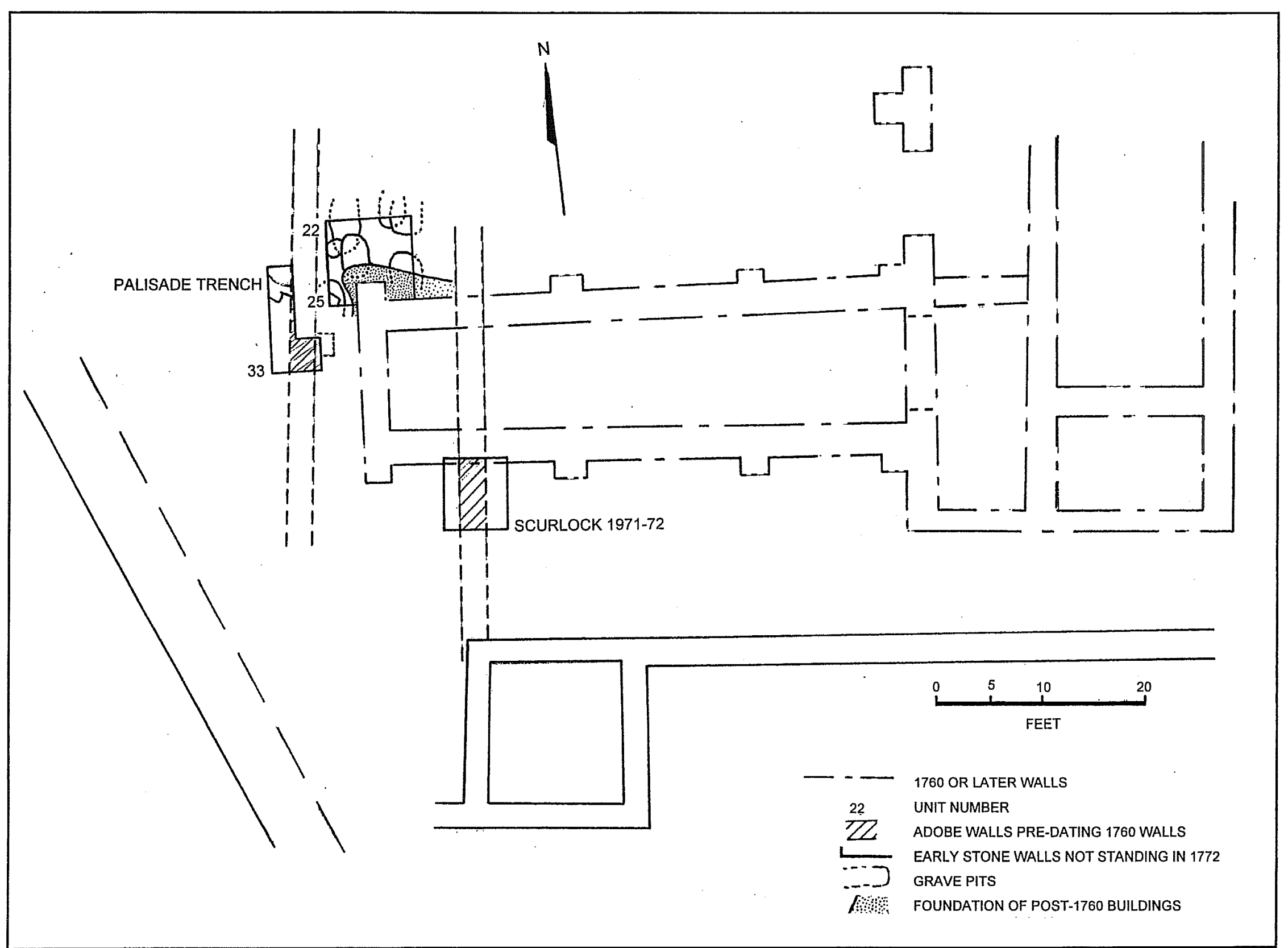

Figure 14. Excavations in the south gate area, Block XIII. 


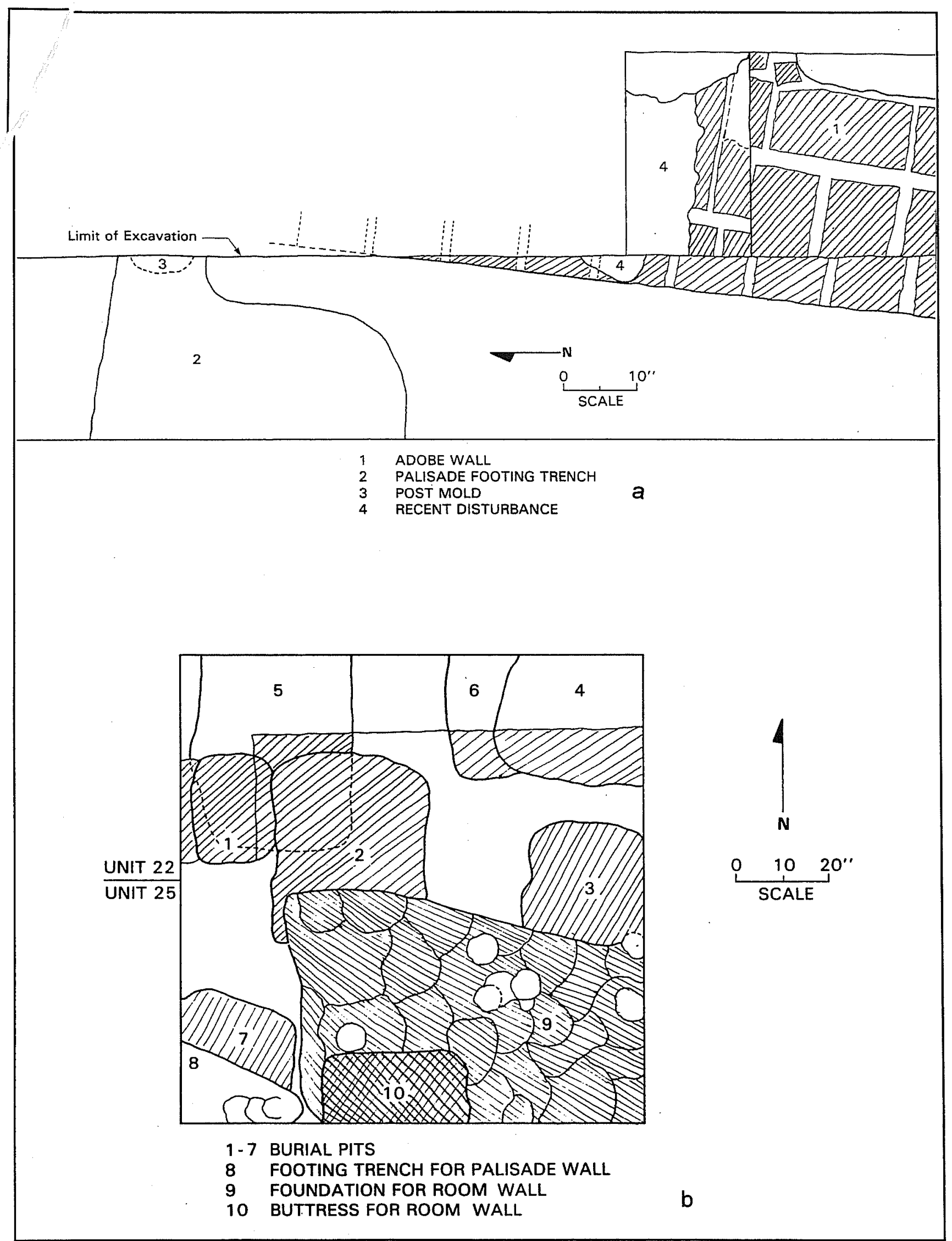

Figure 15. Excavations in the south gate area, Block XIII. a. plan of Block XIII, Unit 33; b. plan of Block XIII, Units 22 and 25. 
trench was in the unit, unfortunately, so we decided to excavate Unit 33 west of the west end of the kitchen ruins to look for wall traces and to determine if the supposed palisade trench continued west.

This unit determined that no stone or adobe wall extended westward from the kitchen ruins. However, the trench-like feature was found again where it crossed Unit 33 (Nos. 2 and 3 in Figure 15a). The outline and some decayed fragments of a large post which had been set into the trench were found in the east profile of the unit, confirming that it had been for a palisade structure. On this profile the trench was seen to be 11 inches wide at its top, tapering to 9 inches in width near its rounded bottom. The post set into it was 7 inches in diameter. The trench extended 23 inches below its surface of origin and 28 inches below the present surface. In plan, the trench widened from 11 inches to 42 inches at approximately 7 inches from the east side of the unit, and remained at this width westward across the rest of the unit. No explanation for this change in plan was apparent.

This odd structural trace was not followed further. It was suspected, however, that it may have been a palisade wall closing the gap between the end of the stone south wall and the end of the kitchen building. The south gate was known to have been in this area, as indicated in the deed records (e.g. BCDR Vol. A2:73, Aug. 17, 1838), and may have been built into this palisade. Further excavation would be necessary to confirm or disprove such a hypothesis.

\section{Early Events in the South Gate Area}

Seven burial pits were found in Units 22 and 25 (Figure 15b), beneath the foundations of the kitchen and in fact cut through by them. These had been dug at various times through a series of puddled adobe floors laid across the width of the area. One of these (Burial 1, an infant) was opened to ascertain whether they were graves. The body was photographed and drawn in place. Several samples of cloth (Appendix IV) that had wrapped the body were removed, and the body reburied. The skull of an adult (Burial 5), buried before the infant was interred, was found at one edge of
Burial Pit 1. Apparently the grave pit for the: infant did not disturb this prior burial. Both burials a ppear to have had the bodies placed on their backs in an extended position. The body of the infant had its head placed toward the north, while that of the adult had its head toward the south. Based on preliminary research for this project, these burials probably took place during the first permanent construction phase, 1731-1750, with Burials 1 and 2 having been interred about 1750 , just before construction of the convento began $\mathrm{ca}$. 1755. The last adobe floor was not patched after these two burials. Above these floor surfaces was a layer of adobe building rubble similar to that seen in association with the adobe walls deep in Block I. In fact, fragments of the same chocolate-colored adobe seen in Block I were found in this rubble. Some of these fragments were mixed into the fill of Burials 1 and 2.

In Unit 33 an adobe wall foundation of the same chocolate-colored bricks was found running northsouth (Figure 15a) with a thin layer of white plaster on its east face. The bottom of the wall was slightly below the surface of construction west of it, which was at the same general depth as the adobe floors in Units 22 and 25 (12-13 inches below the present surface). The adobe wall was apparently built directly on the contemporaneous ground surface, as it was in Block I and in the later adobe walls built as partitions in Blocks VI and VII.

Field notes and drawings of the THC excavations revealed a similar wall east of the one found in Unit 33. This was south of the south foundation of the kitchen rooms and was cut across by this foundation. It paralleled the adobe wall in Unit 33. The space between the two walls is estimated to be about $14.5 \mathrm{ft}$.

The evidence of these adobe walls and floors, the traces of white wall plaster on the interior of one of the walls, and the location and orientation of the burials argue that these are the remains of the adobe church of Mission Concepción, in use from about 1730 until the completion of the stone church in 1755 . The burials were probably those of Indian neophytes. A very similar church with its associated burials was found at Mission San Lorenzo, 1762-1771 (Tunnell and Newcomb 1969:15-22, Figures 7-9). A second example of 
such a church is at Mission Rosario (Gilmore 1975:Figures 7-9). The length of the adobe church is unknown, but were it the same proportions as that at San Lorenzo, it would have been 37 or $38 \mathrm{ft}$ long. If it were of the proportions of the first Rosario church, it would have been about $60 \mathrm{ft}$ long.

[Note: The NPS excavations of 1982 further examined this structure and confirmed that it was indeed the adobe church (Ivey 1982). It was found to be $61 \mathrm{ft}$ long, exterior measurements, and to have had a stone room built onto its south end. This stone room, probably the sacristy for the church, was attached to the stone foundations located by Smith in 1936 and further examined by Scurlock et al. in 1971-1972. Currently it is considered likely that these foundations are those of the first stone convento of Concepcion, discussed below in the Structural History Section.]

\section{The Plaza Area}

Units 20, 21, 23, and 24, forming Block XIV, were established in the plaza of the mission pueblo. Units 20,21, and 24 were placed on one of the possible alternate lines of the south wall, and Unit 23 , west of Mission Road, was intended to check on the surviving stratigraphy in that general area.

Units 20,21, and 24 found severe disturbance in the area just east of Mission Road in front of the present church. Traces of old twentieth-century parking lots and flower beds were found, bottoming out on sterile earth. Unit 23 found no clear stratum of colonial debris west of the road.

\section{Summary of the South and West Walls}

The THC excavations in 1971-1972 located a fragment of foundation, which was interpreted as the west wall in this area, near the conjectural position for the wall and with virtually the same compass orientation, but offset from the conjectural inner wall line about $8.4 \mathrm{ft}$ to the east (Figure 5). Judging from the drawings and photographs, this is indeed a wall fragment. How this structural remnant fits into the plan and history of the rest of the mission was not determined during the CAR excavations. However, the information from deed records and the few fragments of wall-like remains found on the south side can be fit together into a speculative plan of the south wall area (Figure 4). This plan assigns the pavement-like wall traces in this area to be the outer, not the inner wall, unlike the rest of the mission pueblo. The foundation excavated by the THC, then, may have been a partition wall on the east side of a room in the southwest corner of the mission compound.

Overlying the few remnants of mission-period walls and trash pits are several concentrations of latenineteenth- to early twentieth-century trash dumps. These, too, were disturbed by the reported bulldozer scraping of the area in the late 1950s. The artifacts from this period, found by our excavations and by those carried out by the THC in 1971-1972, offer archaeological evidence in support of the local oral historical testimony that this scraping occurred. THC Unit 77, dug into the earth fill in the old stone quarry, produced a number of sherds of clear-glazed whiteware from a large, ornately molded pitcher. These sherds were omitted from the artifact provenience table in the THC report (Scurlock and Fox 1977:75-76) for some reason, but they are clearly labeled in the artifact collection. Many of these cross-mend with another collection of sherds from the same pitcher, found in place in the undisturbed lower portion of a shallow trash-burning pit during our excavations of Units 49 and 50. Apparently the upper portion of this ca. 1900 trash midden and its pitcher sherds were scraped off and shoved into the quarry as part of an attempted filling operation.

The final, definitive study of the plan and location of the south and west walls must await a painstaking peeling of the entire wall area. The determination made during these investigations that these wall traces will likely be encountered just below the present surface is a critical one. Before, it was thought that the colonial surfaces were two or three feet deep in the south and west wall areas. This determination will make future excavation much simpler, but will require a different, far more delicate approach than the deep test pit. 


\section{Artifact Analysis}

For simplicity the majority of the artifact analysis is presented in tabular form by provenience and material category in Appendix V. Textiles are analyzed in Appendix IV. Ceramics (Figure 16) are discussed some detail below and listed in Tables $\mathrm{V}$ $2, \mathrm{~V}-4, \mathrm{~V}-6, \mathrm{~V}-8, \mathrm{~V}-10, \mathrm{~V}-12$, and $\mathrm{V}-14$. Nonceramic artifacts are listed in Tables $\mathrm{V}-1, \mathrm{~V}-3$, $\mathrm{V}-5, \mathrm{~V}-7, \mathrm{~V}-9, \mathrm{~V}-11$, and $\mathrm{V}-13$. The collection is divided according to the most likely area of use for the artifacts, such as kitchen/dining utilization for bottles and tableware (Figure17 d-f), construction areas for nails and window glass, or arms-related (Figure 18), including a Spanish escopeta trigger guard (Figure $18 \mathrm{c}$ ), which is analyzed in Appendix II. Two categories do not precisely follow this system; the ceramics category, which is separate from the kitchen/dining category and is subdivided according to decoration and method of manufacture, and the Indian group, into which was placed all stone tools other than gunflint, and worked bone and shell (Figure $19 \mathrm{a}-\mathrm{k}$ ).

Only those artifacts which are unique or are of importance in dating and identifying specific deposits have been selected for illustration and identification. Most of the dating information is derived from the ceramics. For a more detailed discussion of the artifact categories listed in Appendix $\mathrm{V}$, the reader is referred to Fox et al. (1976), Gilmore (1974, 1975), Greer (1967), Noël Hume (1970), and Schuetz (1969).

Black and white photographs of pottery sherds are likely to be more confusing than explanatory; therefore, only those sherds are illustrated which pertain to the discussion in the text and contain clear evidence of the overall pattern of the variety they represent (Figure 16). As in most Spanish colonial sites in Texas, the majority of the sherds are too small to indicate much more than the basic color combinations represented.

\section{Classification of the Ceramics into Chronological Groups}

In an archaeological testing program on a specific site, artifacts serve a somewhat more limited purpose than would be the case in the extended excavation of complete rooms, structures, or other full features. The predominant function of artifact analysis in limited testing such as was conducted at Mission Concepción is chronological. It is used to supply dating information about structures: approximately when they were built; and roughly when, for one reason or another, they ceased to be used. This, in conjunction with historical research, permits the identification of building phases as described in the documents. These artifacts also permit a general classification of features into aboriginal, Spanish/Mexican, or Anglo-American archaeological events. More detailed cultural studies, such as activity patterning within a given structure, cannot be attempted at the testing level of excavation, although some hypotheses on these topics may be generated.

Specific features such as trash dumps placed into features dug for other purposes (acequias, for example), or into pits purposely dug for trash disposal, offer some chance of deducing activities on the site that might have produced a particular collection of discards. This sort of deduction is usually very limited in scope and very general in detail.

The ceramics collection contains most of the dating information about Mission Concepción. The classification approach employed here differs somewhat from that normally used in archaeological reports, as follows: a type name must be associated with a specific, known fullplate pattern and a well-defined range of dates of occurrence. Names that have no specific plate pattern or date range are not considered types, but rather color classifications or categories.

In general, those groups resisting classificatio demonstrate the same basic tendency: three or four plate patterns appear to dominate the sherd collections, but a number of other variant pattern fragments also occur. These are usually sufficiently similar to various elements of the dominant groups to cause confusion when trying to recreate complete designs. Work, patience, and a good visual memory will eventually solve these problems, but there will always be a random group of sherds which will resist typing. 


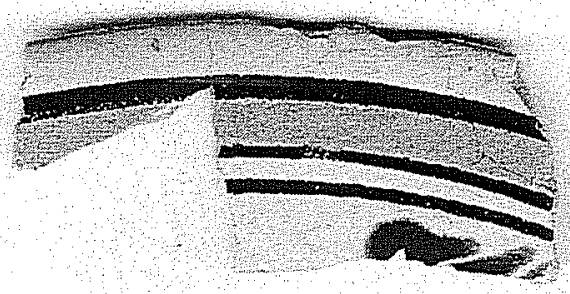

$a$

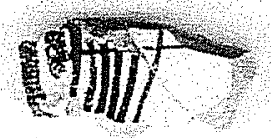

d

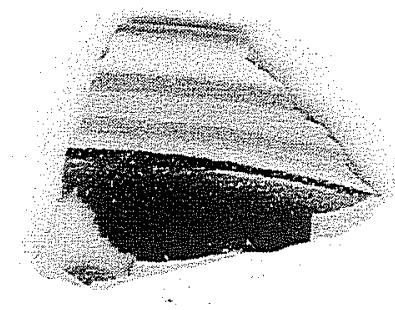

$b$

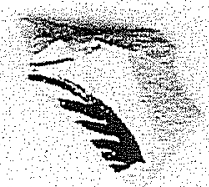

$\Theta$

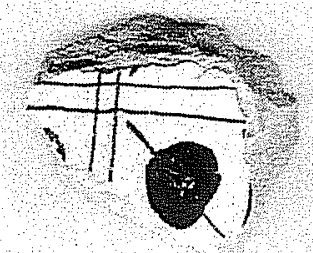

C

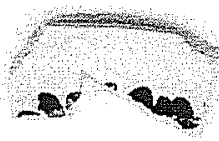

f
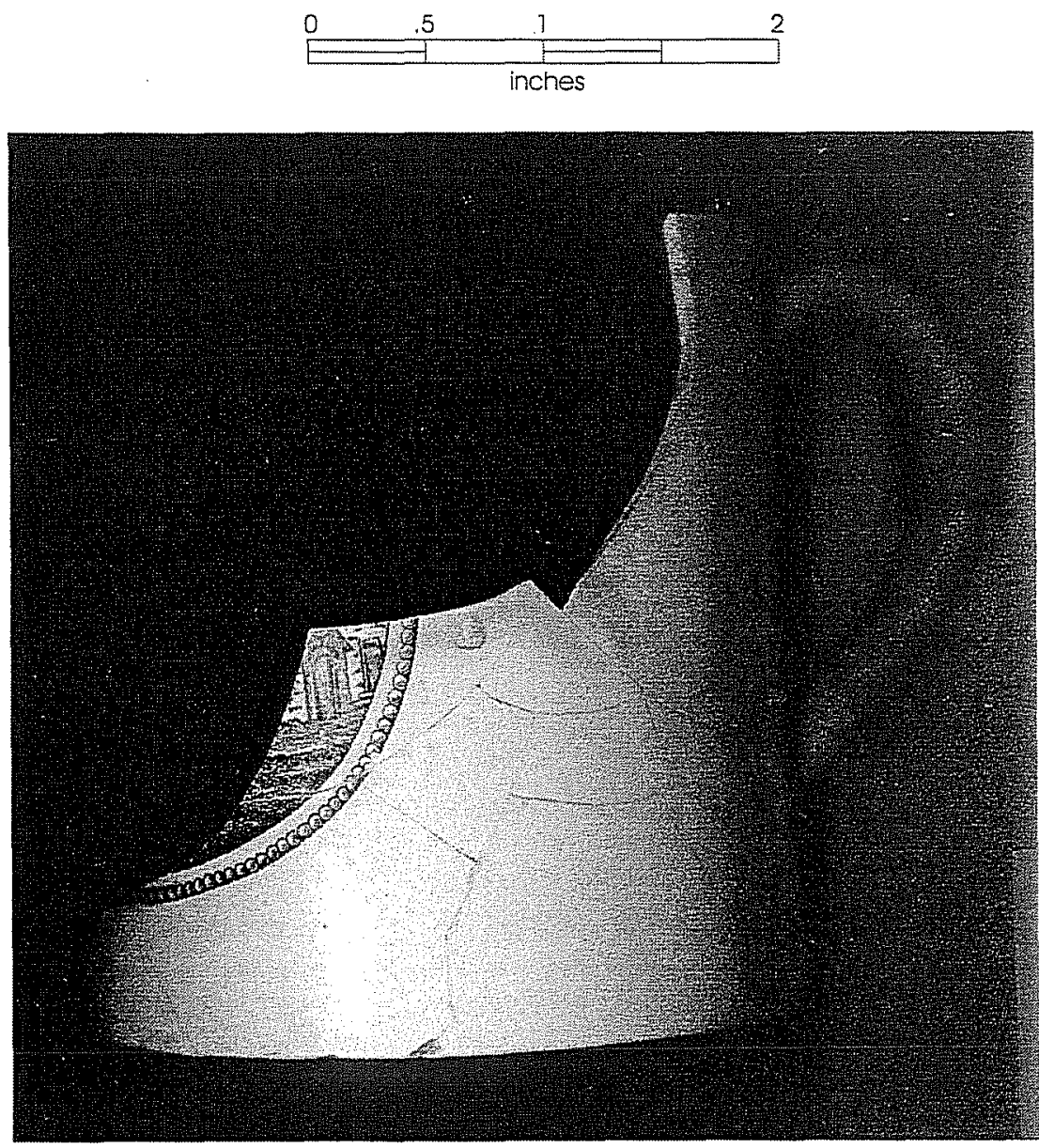

g

Figure 16. Ceramics. a. Orange Band Polychrome majolica, with pendant blue semiflowers, plate (Block VI, Unit 27, Level 10); b. Monterey Orange Band majolica, plate (Block IX, Unit 36, Level 4); c-e. Puebla Polychrome, plate (Block VII, Unit 29, Levels 2 and 4, and Block VI, Unit 26, Level 14); f. Puebla Polychrome, cup (Block XII, Unit 42, Level 2); g. creamware cup (Block VI, Unit 26, Levels 2-5). 


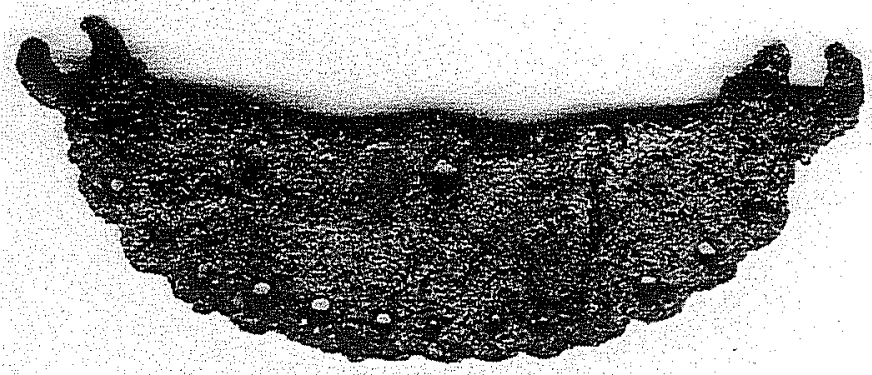

a
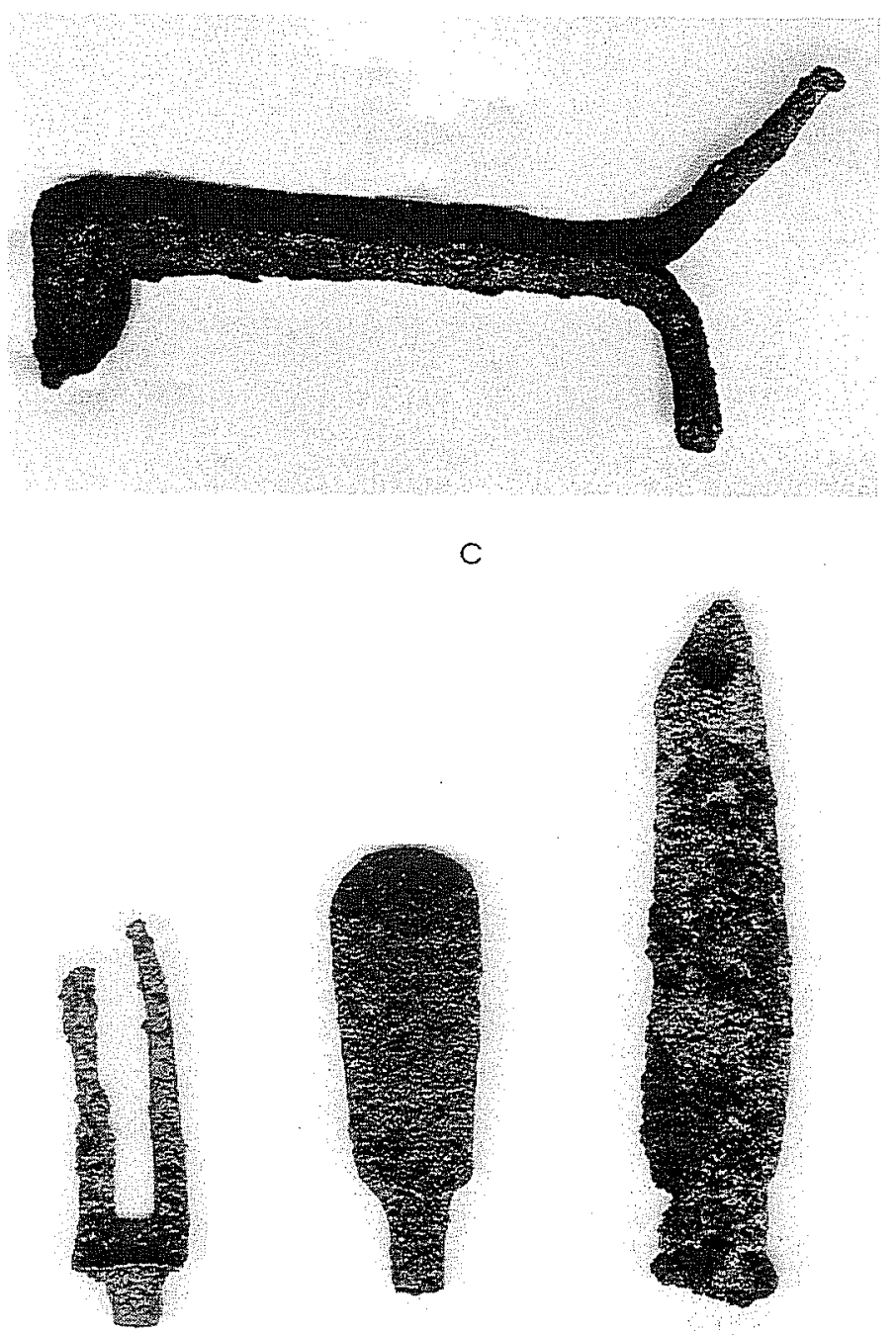

$e$
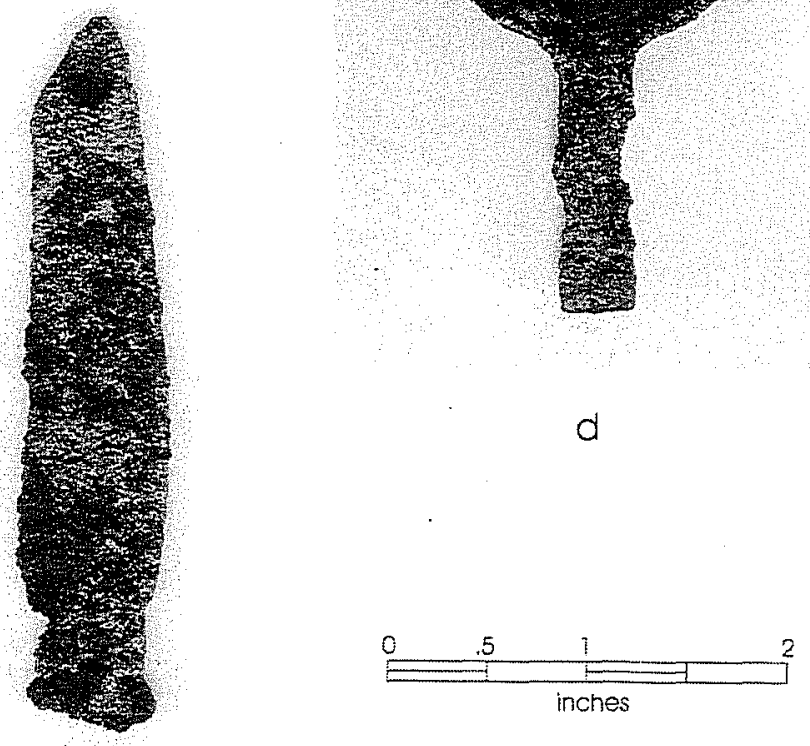

Figure 17. Iron Artifacts. a, pierced bridge from Spanish ring bit (Block XI, Unit 45, Level 1); b, pierced higa from Spanish anquera (Block V, Unit 35, Level 1); c, hand-forged Spanish hinge (Block VII, Unit 37, Level 2); d, iron spoon (Block II, Unit 2, Level 3); e, fork (Block II, Unit 2, Level 3); f, spoon handle (Block VIII, Unit 22, Level 2); g, case knife blade (Block IX, Unit 36). 


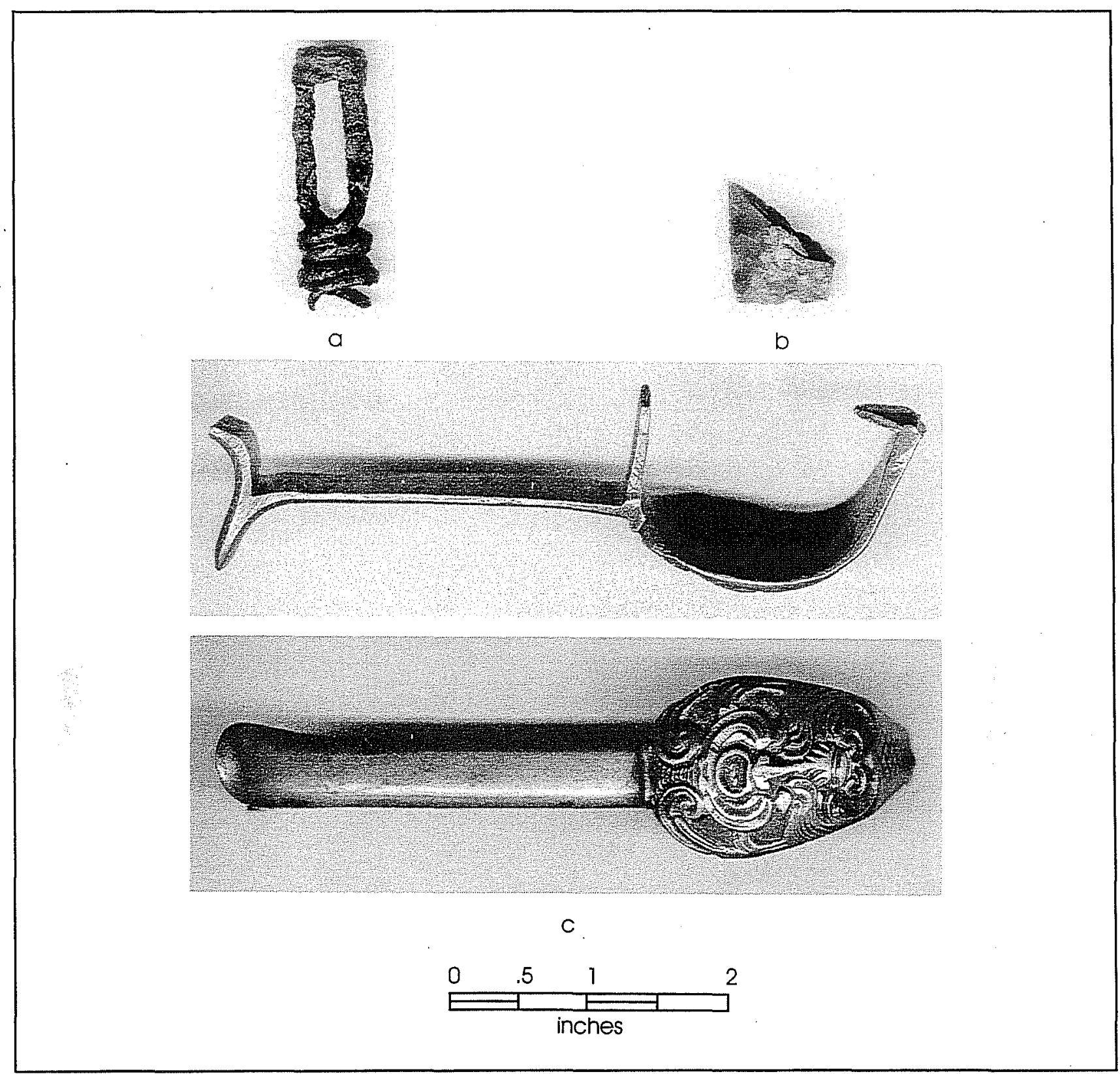

Figure 18. Arms-related Artifacts. a, firearm worm (sacatrapos) (Block VI, Unit 26, Level 9); b, locally made gunflint fragment (Block XIII, Unit 33, Level 4); c, Spanish trigger guard (Block VI, Unit 26, Level 9).

The types and revisions proposed below need to be carefully examined and evaluated in other collections. Dependable dating can only come from analysis of a wide range of sites. These types are being offered as a useful tool rather than as a definitive presentation.

\section{Unglazed Ware}

Fox points out that unglazed ceramics found on Texas Colonial sites tend to fall into two groups, a locally made, hand-built ware commonly called Goliad ware, and a wheel-made type which is more sophisticated both in construction and in firing technique. Goliad ware was fired over open campfires and shows the distinctive dark cores and and variegated surface colors of such firing. The wheel-made pottery was evenly fired to a somewhat higher temperature, probably in a primitive kiln [Ivey and Fox 1981:31]. 


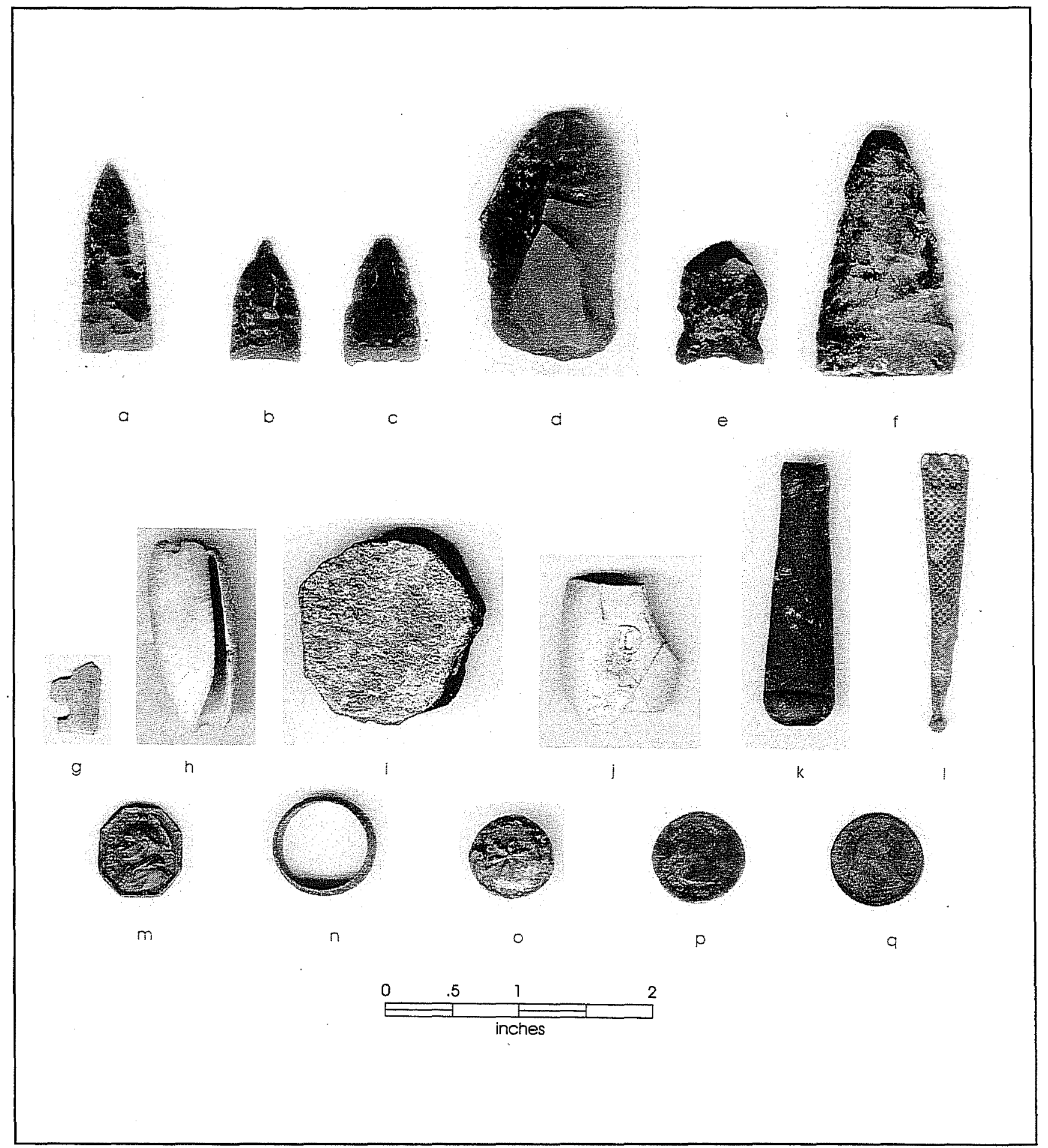

Figure 19. Lithic, Shell and Metal Artifacts. a-c, mission points (Block IX, Unit 36, Level 6-8); d, unifacial tool (Block VII, Unit 29, Level 8); e, prehistoric projectile point fragment (Block XI, Unit 11, Level 3); f, prehistoric biface fragment (Block XI, Unit 5, Level 2); g, mussel-shell bead fragment (Block VIII, Unit 37 , Level 2); h, olivella shell bead (Block XII, Unit 44, Level 1); i, sandstone gaming piece (Block I, Unit 49); j, clay pipe fragment (Block XII, Unit 49, Level 1, fire feature); $k$, composite pipe stem (Block XII, Unit 49, Level 1, fire feature); l, brass finial (Block XII, Unit 49, Level 1, fire feature); m, religious medal, brass with gold wash (Block XII, Unit 12, Level 3); n, finger ring, brass with gold wash, tooled design (Block I, Unit 3, Level 3); o, compound brass button with brazed-on iron shank (Block XII, Unit 45, Level 1); p, coin, silver, probably half-real, 1788 Carolus III (Block VIII, Unit 37, Level 2); q, coin, 1887 U.S. dime (Block VI, Unit 9, Level 1). 
Goliad ware usually has a bone temper, and appears at Concepción from the earliest depositions (ca. 1730 or earlier) to the last days of the mission ca. 1800 . It can be concluded from this and similar evidence from other sites that Goliad ware continued to be made by some segment of the local population throughout the Spanish colonial period, 1718-1821, perhaps even through the Mexican period, 1821-1836, and is probably a direct continuation of local prehistoric ceramic traditions in central and south Texas (Fox et al. 1976:67). The wheel-turned pottery usually has only occasional white flecks and small pebbles of tempering. The paste is usually smooth with very fine to fine sand apparent in some sherds. A red, brush-applied decoration is seen on some sherds. This wheel-turned, unglazed, evenly fired pottery has been termed Valero ware. Based on its occurrence at Mission Concepción, the range of years for popularity was ca. 1730 to 1760 . References to this ceramic may be found in Fox et al. (1976:67), Greer (1967:19), and Ivey and Fox (1981:31), among others. A variety with a red slip or paint coating one or both surfaces may last into the mid-1760s (Tunnell and Newcomb 1969:80-83).

The continuation of the Goliad ceramic tradition through the Spanish and Mexican periods of Texas argues for the survival of associated elements of local Indian culture among the Hispanicized people of the San Antonio River valley and could be taken to imply the continued existence of an Indian subculture with a Hispanic veneer in this area. Evidence from excavations at Rancho de las Cabras, the ranch of Mission Espada, indicates that some residents of the Rancho, from ca. 1755 to 1770 at least, continued to use Goliad ware and some of their own lithic tool traditions along with Hispanic technology and cultural traits (see Fox 1977:16; Ivey and Fox 1981:37; Ivey 1983).

\section{Burnished Ware}

Burnished wares were made following preColumbian Mexican traditions and are still made in some areas of Mexico today. "These include a red ware with burnished designs on a matte back- ground, probably from the Valley of Mexico, and a variety with tan paste, slipped with red, black, or polychrome decoration and highly burnished, which was made in Tonalá, Jalisco" (Ivey and Fox 1981:31, 34). Occasionally a few sherds of black, burnished pottery similar to the red variety are also found. There are apparently several well-defined vessel shapes and decorative designs, but sherds are too scarce as yet in Texas to permit a reconstruction of these details.

\section{Lead-Glazed Ware}

Fox defines two basic groups of lead-glazed wares. These were "comparatively thick-walled, wheelmade bowls and ollas with a sandy paste and a yellow or green glaze," and "thinner-walled vessels with a finer paste, which contains little, if any, sand" (Ivey and Fox 1981:34). This second variety was "made primarily in the form of chocolate pots and bean pots ... decoration consists of dark brown and cream bands, dots, and floral designs, which occasionally have touches of green" (Ivey and Fox 1981:34). This variety of thin, lead-glazed ceramic is called Galera ware. Fox indicates that it began to appear in Texas sites about 1750 and grew rapidly in popularity up to the turn of the century (Ivey and Fox 1981:34).

\section{Olive Jars}

Large earthenware jars used for shipping and storage were occasionally brought to Texas sites (Goggin 1964). However, they were never as prevalent in Texas as in other areas, such as Florida, which were supplied by water rather than by overland trails.

\section{Lusterware}

A few sherds of black lusterware are commonly found at most Spanish colonial sites in the San Antonio River valley. This pottery is still made today in a number of pottery centers in Mexico (Schuetz 1969:52). 
Majolica

Most Spanish colonial dating information is derived from the majolicas. These are tin-enameled wares made in Mexico, predominantly in the city of Puebla. Their patterns of decoration underwent frequent changes through time, which makes them potentially useful chronological indicators.

A number of general classes of majolica were established by the work of Goggin in 1968. These types were assigned time periods applicable across most of New Spain. It has become apparent in our own work, however, that frontier conditions produced some variations in the general rules of type and time established by Goggin. These variations create a need for more specific typological definitions and date ranges for some of Goggin's types; moreover, they will probably result in the addition of new types to his list.

In Texas the major development of Hispanic missions and settlements occurred after 1700 and effectively ended in 1836 for most of the state. Goggin's (1968) typology gives a very low level of definition of chronology in this period, and what he does offer is generalized across the entire area of Spanish and Mexican rather than specific to the Texas area. What is needed is a set of easily recognizable types with date ranges that subdivide the 1700 s and early 1800 s into smaller segments which can be associated with major changes in the plan and pattern of the development of San Antonio River valley settlements. These are in the process of development through work being carried out across the northern Spanish colonial frontier from Texas to California. Several specific types have already been formulated, such as Gerald's (1968:46) San Elizario Polychrome, which has been adopted into general use in frontier ceramics studies, and the more recently defined Monterey Polychrome and Tucson Polychrome (Barnes and May 1972:12, 36), which are only just now being recognized in the field and in collections in Texas. The process of recognizing and defining these types is a slow one. It requires the assembly of a full plate pattern from small sherds found at various times all across Texas and the northern Spanish colonial frontier; the association of the type with a particular time period; and a deduction of whether the particular type was peculiar to a specific kind of site or activity, such as missionary, military, or civil settlements.

Several new majolica types are defined in general terms and used in this analysis. Moreover, the use of some traditional classifications derived from Goggin has been discontinued here in favor of more generalized categories. Other types, whose clear-cut design characteristics and chronological usefulness in Texas frontier studies have been supported by field experience, have been kept.

Puebla Polychrome (Figure 16c-f) is defined by Goggin (1968:173-182) as white plates and cups with fine black lace-like patterns and blue arcs and circles. Goggin dates this type to the years 1650-1700. It is rare in the San Antonio River valley, but one or two sherds usually are found in the earliest sites. This pattern of occurrence leads us to believe that Puebla Polychrome was going out of use in San Antonio ca. 1725, but may appear in an undisturbed context as late as the early 1730 s.

"Aqua Green-on-white" plates have an orange, sandy paste, a coarse greenish white enamel, and dark green to aqua markings. The type most resembles a variety described by Lister and Lister (1982:28) as being Mexico City Green-on-cream. One such sherd was found in the fill of an acequia on the grounds of San Antonio de Valero. This acequia was filled, apparently intentionally, ca. 1725 (Fox and Ivey 1997).

"Blue-on-white" is a catch-all category for those majolicas which have blue decorations on white enamel, with no other identifying characteristics. Goggin defined a type called Puebla Blue-on-white into which this sort of ceramic is usually classed, but he warned, "this type really comprises a great series of forms, many of which eventually will be considered valid types-distinctions apparent in complete vessels are not so easily recognized in sherds" (Goggin 1968:190, n. 53). "Blue-onwhite" has become too comfortably accepted among Texas archaeologists, and there has been some resistance to forming new varieties from it. A notable exception is Gerald's (1968) San Elizario, discussed below. It is felt that the use of what sounds like a formalized type name for these ceramics has tended to discourage speculation on new types and their chronological associations. 
San Antonio Blue-on-white is a proposed variety to be separated from Goggin's Puebla Blue-on-white. It is identical to San Elizario in full plate pattern except that it has no black accents or outlines. Instead of the single blue rim band accented on both sides with black lines, as seen on San Elizario, it has a double blue rim band, the outer band usually being somewhat broader and darker than the inner band. On some sherds the two bands come into contact, giving the impression that only one broad band is present. The central decoration is usually a bird of the same design as seen on San Elizario, but again with no black accent. This type was first described by Tunnell (1966:7) as his Style 1. A large rim fragment was illustrated in Barnes and May (1972:Plate 1d). San Antonio Blue-onwhite is probably related to similar varieties illustrated in Goggin (1968:Plate 16,e) and Lister and Lister (1974:Figure 10a, b). In small sherds it is usually very difficult to differentiate San Antonio Blue-on-white is tentatively ca. 1730 to 1750 . It appears to be a precursor for San Elizario (17551780) and seems not to overlap chronologically. The similar types illustrated by Goggin (1968) and Lister and Lister (1974) appear on Texas sites from perhaps the $1720 \mathrm{~s}$ well into the late $1760 \mathrm{~s}$, overlapping San Elizario (e.g. Calhoun 1968:22-23; Gilmore 1969:Figure 12g, I, p; Tunnell and Newcomb 1969:Figure 45).

"Blue and Green-on-white" sherds seem to be almost entirely from cups. They are similar in decoration to "Blue-on-white" cups, but have green instead of blue floral elements associated with blue horizontal bands. Such sherds are seen occasionally in San Antonio sites (Schuetz 1969:56, Plate 27I). No dating is available.

"Blue-on-white Molded" sherds are equivalent to Gilmore's (1974:51) "Other Duochrome, Scalloped rim," Style 1, Groups a and c. Dating information is not precise, but it probably dates to the second half of the eighteenth century. The pattern seen on Gilmore's (1974:Plate 11a, c) Group c shows little variation from site to site as revealed by comparisons of the ceramics from the San Antonio missions in CAR's collections. If good dating can be achieved on Gilmore's Style 1, Group c, it should be separated as a type.
Another catch-all group like Puebla Blue-on-white is San Agustin. Goggin (1968:187-189) suggests a date range of 1700 to 1730 . When defining it he apparently had a clear-cut pattern in mind, but his description and illustrations are not sufficient to permit effective use of the type. It is currently used for plate sherds with blue arches or any sort of blue marking on the underside, or for sherds which have two shades of blue with the paler outlining the darker. As in Puebla Blue-on-white, there seem to be several consistently repeated designs which appear on the majority of sherds, with recognizable blue arches on the underside. Usually combined with these sherds in collections are several similar designs having pale blue concentric circles on the underside. In both cases, the complexity of the designs on the upper surface makes individual designs very difficult to recognize on sherds, but in all probability this difficulty would be lessened considerably with the completion of a full plate design pattern. Again, dating information is necessary before types can be proposed. For simplicity, San Agustín is retained in this study as a general category name.

San Elizario was proposed and described by Gerald (1968:44). Dates on Texas sites range from ca. 1755 to ca. 1780 . It is a very useful type because it is easily recognized, even in small sherds, and is fairly common during its date range. See San Antonio Blue-on-white for its description.

"Orange Band Polychrome" is a catch-all color group, equivalent to what is usually called Aranama Polychrome. The name "Orange Band Polychrome" is taken from Barnes's study of Arizona majolicas, although he uses it in reference to two specific patterns rather than as a general category (Barnes and May 1972:12-13). May proposes that Aranama Polychrome should instead be called the Aranama Tradition, and in effect defines it as including any polychrome that has an orange rim band (Barnes and May 1972:34). Here, a general color classification, "Orange Band Polychrome," is preferred for a working category out of which are defined specific full plate or cup designs. These are then given date ranges through archaeological evidence. Only when this has been accomplished should a separate type be proposed. 
Aranama Polychrome has in the past been used to identify everything from Goggin's (1968:169-173) Abo Polychrome, dated 1650-1700, to designs that are clearly associated with the complete reform in design and color occurring after 1810 . The only criterion has been the presence of yellow, green, or orange decorative elements or, in some instances, virtually any color combination other than blue on white. This practice is not conducive to effective type-defining or chronological association.

For the purposes of this analysis, all nonnineteenth-century polychrome sherds which cannot be assigned to some specific type have been included in the category "Orange Band Polychrome." This is because most of these polychromes are indeed orange-banded. The working category is dominated by sherds of two fairly distinctive types. For one of these, the full plate pattern has not yet successfully been worked out, even though it has a fairly clear chronological position. The other is orange-banded with blue semiflowers suspended from the band (Figure 16a). Examples matching this description have been found at several sites on the northern Spanish colonial frontier in Texas and Florida. Among these are the second site of Presidio Nuestra Señora de Loreto (La Bahía), 1725-1750 (Calhoun 1968:38 Figure 5b, c) and the San Xavier missions, 1746-1755 (Gilmore 1969:92; Figure 12m). Full plates with similar edge designs were found at Santa Rosa Pensacola, Florida, 1720-1750 (Smith 1965) and probably represent the plate patterns from which these Texas fragments came. The Florida plates have polychrome floral centers, or versions of Goggin's (1968:197) "eunuch-like" figure, as described in his discussion of the Aranama Polychromes. The date range of these patterns seems to be ca. 1720 to 1750 . In spite of the similarities, the pattern does not seem to be Goggin's (1968:160) Mount Royal Polychrome which he dated to ca. 1650. Rather, it looks like a variant of his Aranama with blue semiflowers instead of green and yellow balls. It probably should be given a type-name, but since the Texas examples are very rare and the pattern relationship with the Santa Rosa Pensacola material is largely conjectural, the typing is left to others with a better sample.
Monterey Orange Band (Figure 16b) is a type defined by combining the descriptions of both Barnes and May (1972:12, Plate 1n, 36) and using May's name for the pattern. It is quite distinctive even on small sherds and is a good time marker for the period ca. 1790 to 1810 in Texas. It usually dominates polychrome sherd collections, forming as much as 50 percent of the polychrome sherd count on some sites. A nearly complete plate of Monterey Orange Band is on display in the museum at Mission Espiritu Santo at Goliad, Texas.

Tucson Orange Band, a type also taken from the combined work of Barnes and May (1972:12; Plate $10 ; 36)$, consists of six green floral elements of two alternating types suspended from the orange rim bands. In the center is a green crane and one of the flowers is a carnation, both elements very similar to those of San Antonio Blue-on-white and San Elizario. The other floral element is a large, open flower with yellow petals or balls flanking green petals and brown-black stems. The green is unusually dark and intense, allowing identification of comparatively small sherds which bear portions of the design. However, the identifying elements cover a relatively small area of the total plate surface. A full plate pattern can be found in a photograph of several plates attached to a wall at Calpulalpan de Méndez, Ixtlán, Oaxaca, illustrated in the Vocabulario Arquitectónico Illustrado (Secretario del Patrimonio Nacional 1975:299). Its occurrence on Texas sites is rare and usually dated in a 1790 to 1810 context. Barnes and May $(1972: 13,36)$ assign it to a post-1820 context. A small sherd of this type was illustrated by Deetz (1978:183, Figure 15, k) from Mission La Purisíma in California in a post-1812 context.

Huejotzingo is a standard type into which is put all rim sherds with a single rim band of blue, green or yellow. The lower edge of the band may be straight or wavy. So far, the general indication is that the straight-band varieties frequently had a central design (e.g. Lister and Lister 1974:Figure 7c; Secretario del Patrimonio Nacional 1975:299). Goggin dates this type from 1700 to the present, which makes it relatively useless for dating in Texas, unless further work can refine this date range or find different ranges associated with the several varieties. 
"Majolicas from the nineteenth century" is a category of sherds which have the general characteristics of the post-1810 period but for which no specific types have been established. These are characterized by new color combinations in gray, dark mahogany brown, and odd blendings of green, yellow, and brown among others. Designs are frequently new and varied. A selection can be seen in Lister and Lister (1974:Figure 11), and Seifert (1977) has established a few types. Probably the most frequently seen design of this group is that illustrated by Lister and Lister (1974:Figure 11f), which occurs in a wide range of color combinations. This is characterized by an edge-decoration consisting of a chain of alternating diamonds and ovoids. An almost identical pattern has been observed, from an eighteenth century English colonial context, on as disparate a medium as etched drinking glasses (Leighton 1973:78, Figures 1, 2).

Guanajuato, another standard type, is characterized by a brick-red, smooth paste in most-but not allsherds, a smooth green-tinted white enamel, and decorations in aqua green, orange brown, occasional black-brown accents, and occasional orange or yellow elements (Lister and Lister 1974:Figure 12). This appears to be a post-1810 time marker.

Tumacacori is a blue majolica with small decorative floral elements in black, yellow, green, orange, and dark blue. Goggin (1968:198-200) dates it to ca. $1820-1830$. It is usually easy to identify the pale blue surfaces of the sherd, even on very small sherds.

"White ceramics" is a category for any sherd showing no apparent decoration. Some of these sherds will be from undecorated vessels, while others will be from undecorated areas of decorated vessels.

Faience is a tin-glazed ware made in France, frequently found on Spanish colonial sites in Texas. Comparatively little is known about the dating and source of these ceramics for Texas sites. They had reached the frontier by the early eighteenth century (see Tunnell and Ambler 1967:33-39), and it has been demonstrated that they can be associated with a chronological context as late as the second half of the century (Ivey and Fox 1981:35).

\section{Chronological Information from the Artifacts}

The artifacts found in Spanish colonial sites can be grouped into a series of "typical collections" indicating general periods of time. Artifacts consistently present throughout the Colonial era would include fragments of copper, an occasional hand-forged nail, possibly some iron fragments, a few glass fragments, several gun flints, numerous sherds of Goliad ware, a number of chert tools, and small projectile points. In addition, a changing assortment of majolica sherds provides helpful time markers. As analysis continues, more types will be defined which will allow more exacting chronological analysis.

\section{Early Mission Period}

For the period from 1718 until ca. 1730 , a standard collection would include a quantity of indeterminate Blue-on-white majolica sherds, perhaps a few sherds of early Orange Band majolicas such as the variety called Abo, some thick lead-glazed sherds, and a number of unglazed sherds. The strongest indicator of this period, however, would be a few sherds of Puebla Polychrome. Occasionally we see a fragment of Aqua Green-on-white. Some San Antonio sites have an occasional fragment of San Luis Polychrome (Scurlock and Fox 1977:59). Although none was seen in this excavation, Scurlock and Fox found one sherd in the fill of the probable acequia in the THC units west of Mission Road. Unglazed, wheel-turned Valero ware would be seen late in this period, beginning ca. 1730 .

\section{Middle Mission Period}

From 1730 to 1755 the general collection would be the same as above, but none of the early time indicators would be present. The Blue-on-white majolicas would begin to show examples of San Antonio Blue-on-white. Valero ware would form a fair percentage of the unglazed sherds, and some Galera ware would begin to appear late in the period. 
Late Mission Period

From 1755 to the 1780 s we find again the same basic artifact collection. San Elizario is the time marker for this period, and Galera ware becomes common. Valero ware disappears.

Secularization Period

After 1780, San Elizario begins to disappear and the late Orange Bands become common. Such types as Monterey, Tucson, and several other as-yetunnamed varieties appear. The Orange Bands are the marker for the period from 1780 until ca. 1810 .

\section{Mexican Period}

About 1810 the majolicas undergo a revolutionary change in design and color, and whole new classes appear that have little resemblance to earlier styles. This is probably the result of the Mexican independence movement, which apparently caused the disruption of old ceramics guild rules about design and color, and permitted new experiments. Guanajuato and a number of similar designs using dark browns, grays, blues, and other colors with a distinctive rim pattern are usually found. AngloAmerican ceramics, which appear only very rarely before 1820 , begin to increase in quantity.

\section{Chronological Patterning from the Artifacts}

The artifacts found in undisturbed stratigraphic deposits show some chronological patterning. That is, artifacts characteristic of certain time periods tend to be found in particular regions of the site. Using the above described chronological groups, we can summarize these patterns.

Early mission material is found in an undisturbed context predominantly in three specific features. These are the trash pit and the probable acequia seen in Units 9, 26, and 27 (Block VI), and the probable acequia in Unit 42. The trash pit in Units 9,26 , and 27 (Block VI) can be attributed to the first years of occupation in this area by Mission Concepción, immediately after 1731 .

The remaining early features cannot easily be explained in terms of the known history of
Concepción. The two features in Blocks VI and XII seem to be acequias which were filled with silt and trash in the 1720s. They may, in fact, both be part of the same acequia. The THC (Scurlock and Fox 1977) found a deposit of early material in the area of Block XII, although the provenience of these artifacts within each of his units or features cannot be determined from Scurlock's notes. The combined information from his excavations and those of CAR indicates that an extensive deposit survives in this area in the lower part of a deep feature; the upper portion has been destroyed. This deposition is the result of an occupation that seems to predate the establishment of Mission Concepción on this site. The historical record suggests that if the estimated date range is correct, the acequia or acequias seen in Blocks VI and XII must be traces of the first site of Mission San José y San Miguel de Aguayo.

The Middle Mission period material is found in the area of the south gate, granary, and the east wall. They indicate that through the Middle Mission period, 1730-1755, the occupation at Mission Concepción was located principally in the area south of the present church.

Late Mission material is found across the Middle Mission core area and out to the limits of the mission pueblo, north of the present church. This implies that construction of the pueblo took place after 1755 , and historical information argues for a date in the early 1760 s. All later material, from the secularization, Mexican, and later periods are found throughout the final plan of the mission and pueblo, indicating a continuous use of these areas in one way or another through this time.

\section{Conclusions Based Upon the Artifact Analysis}

Comparison of the artifact information from Concepción with the archaeology conducted at other Spanish colonial sites in the San Antonio River Valley allows us to consider several hypothetical explanations for the origin of artifacts found on these sites. Two such hypotheses are discussed below. 
Handmade Ceramics and Indian

Cultural Continuity

An examination of Spanish colonial sites throughout San Antonio and south Texas reveals that a large proportion of the ceramics collection is composed of Goliad ware. This handmade, nonkiln-fired pottery was almost certainly made in south Texas.

Goliad ware was first described and named by Mounger (1959) using a large artifact collection from Mission Espíritu Santo at Goliad, Texas. Mounger concluded that Goliad ware was made by the Aranama and other Indians of the mission and represented their aboriginal ceramic tradition (Mounger 1959:181). She noted that Goliad ware is quite similar to Leon Plain, which is an aboriginal pottery type found in central Texas (Suhm and Jelks 1962:95) and south Texas. In fact, it appears that there are few points of significant difference between the two ceramic types.

Evidence that lithic tool making and utilization continued through the Colonial period at the missions has been noted for some years. This has been supplemented by recent excavations at nonmission sites (e.g., Fox 1977; Ivey and Fox 1981), which indicate that the same pattern occurred outside the missions. This, taken together with the continuation of the Goliad ceramic tradition, leads to a specific hypothesis. It is suggested that some Indian cultural structures survived the transition from an aboriginal to a Hispanic culture endured by the local groups of Texas, and were maintained within Hispanic society under a veneer of Hispanic traits through at least 1800 . The survival of a complex of traditions associated with pottery making and a second complex associated with lithic tool making and use at least implies the possibility that other cultural components also survived, of which these two complexes are merely the most obvious traces (e.g. Fox 1979; Hester 1978). This assertion is being made here with caution because several unknown variables are hidden in the underlying assumptions. Among these, for example, is the consideration that the various Indian cultures of the San Antonio River Valley probably differed greatly in their cultural traits.
Historical research has begun to suggest that the San Antonio missions suffered from a continuous loss of Indians to the secular Hispanic world. Some Indians apparently remained in the mission only a short time before moving on into the Spanish towns (Castañeda 1942:25; Leutenegger 1981:32, 34; Schuetz 1968:53, 58). If this were a frequent occurrence, it could be said that the missions succeeded too well in their attempt at acculturation of the Indians (this idea was originated by Schuetz and is fully discussed in Shuetz 1980). This short period of cultural indoctrination and rapid entry into the anonymity of the Spanish town may have produced a group of town or ranch residents who had learned the minimal number of attributes necessary to function within the Spanish cultural system. Under this protective coloration, the remainder of the attitudes and methods of living would have been changed only slightly from the aboriginal. If such a pattern of "protective acculturation" occurred, it would produce a set of cultural traits recognizable in the archaeological record, some of which we have probably seen already in the form of lithics and handmade local ceramics within certain colonial contexts. It is suggested that the occurrence of these materials in previous excavations be re-evaluated, in search of regularities of association, such as with households of particular status, activities of particular kinds (such as ranching, for example) or specific artifact sets. Unfortunately we do not as yet have a good picture of the protohistoric cultures of the Indians of the San Antonio region to give us some clues or guidelines to behavior. This will make it difficult to recognize traits seen in a colonial context as being aboriginal.

\section{The Mission Supply System and Ceramics}

The European ceramics in the collection arrived on the site by a different system than that of the Indian ceramics and lithics. Some characteristics of the occurrence of these ceramics can be used to construct a model explaining this process.

Certain majolicas occur far more frequently than others. In addition, we are beginning to suspect that the appearance and subsequent disappearance of a given type may be quite abrupt, and that the proportional frequency of a given type is about the same wherever it is found in the San Antonio River 
Valley. For example, San Elizario seems to appear abruptly about 1755 in Texas and disappear equally as abruptly in the 1780 s, and one Orange Band type called Monterey usually dominates any Orange Band collection in which it is found. Much more study of the CAR collections and closer communication with other research groups is necessary, however, before such conjectures can be stated as rules or clear tendencies.

A hypothetical explanation of the patterning of frequency and chronology of the majolica as found in the Texas missions is being considered at present as part of a study of the mission supply system. Some of the main points of this hypothesis are summarized here.

The vast majority of manufactured goods acquired by a mission apparently arrived by a mule train supply line from mission authorities in Mexico and, ultimately, from major trade centers. Records of the goods ordered by Mission Concepción each year from 1745 to 1772 have been found in the microfilm collections of the Old Spanish Missions Historical Research Library at Our Lady of the Lake University. These document the annual ordering of ceramics along with the innumerable other items required each year by the missions. The categories of ceramics ordered were extremely general and will probably not provide any typological information. Some assumptions can, however, be made as to how the process affected types and frequencies found in the discarded material of a mission.

It can be assumed that the relatively low level of financial support given to the missions, the vows of poverty taken by the Franciscans, and the cumbersome mechanics of the supply system itself all tended to influence ceramics purchasing in the direction of "bargains." Aesthetic considerations of the design or coloration of a given kind of majolica seem not to have entered into the selection process. In fact, it is suggested that the ceramic types and frequencies found in Texas were caused by the purchase of whatever varieties of majolica were beginning to form backlogs in supplier stocks as their popularity dropped off among the general consumer population of Mexico. In other words, dating and frequency of ceramics in Texas may be the result, not of actual production curves and dates of first and last manufacture of a type, but of its peaking and decline in popularity. In addition, much of what is found on the Texas frontier may not have been the best, or worst, ceramics but merely the best bargains available at the time they were purchased. The random appearance of ceramics from personal possessions, or those which were purchased for special purposes, or those which arrived on site through agencies other than the mission supply system, would tend to confuse this pattern (see Lister and Lister 1976 for a discussion of some aspects of this).

It should be pointed out that one result of the model proposed here for majolica's appearance on the frontier in mission-supplied sites would be a tendency for the time ranges to be peculiar to Queretaran or Zacatecan-supplied sites. Civil and military sites, supplied by other than the missionary system, will perhaps show somewhat different time ranges for the majolicas and different frequencies for the various types insofar as the supply systems were separate (there is good evidence that the mission supply system was also used by the military in San Antonio, and perhaps even by secular civilians-see for example Fr. José Rafael Oliva, Dec. 31, 1788, in Leutenegger 1977a:49). Furthermore, there need not be too direct a link between the majolica types and chronologies in the mainstream of the consumer markets of Mexico and those of the mission frontier.

The two hypotheses discussed above are intended to offer some ideas concerning the mechanism whereby some artifact classes arrive on historical sites, and why they occur in the patterns they do. These ideas are speculative, and should be evaluated as such. It is suggested that such speculation is essential to the development of an understanding of cultural change on the Spanish frontier, and that making current thinking available to others is the best way to hasten this development.

\section{Structural History}

Based on the excavations, a tentative structural history of Mission Concepción can be constructed. 
Missions often went through three phases: a temporary phase in which most of the construction is of jacal; an interim phase beginning when more permanent structures of adobe are built; and a permanent phase in which stone structures predominate. Jacales are simple, quickly constructed huts of brush and wood, sometimes with a coating of adobe over a post or pole framework. These are very temporary and require constant maintenance to remain serviceable. If a site is unsatisfactory, it is no great loss to abandon these structures and build others at a better site; Mission San Antonio de Valero and Mission San José were both moved during their temporary phase. The interim phase began when a site seemed after a period of occupation to be acceptable, and it was decided to build semipermanent structures. Once the necessary buildings of the mission were standing as good adobe structures, the slow process of rebuilding in stone commenced. Usually, as at San Antonio de Valero and Concepción, the convento was built in stone first, the church second, and the workrooms and Indian quarters last, with the jacal and adobe versions of these continuing in use until the new buildings were completed.

\section{First Occupation of the Site}

In 1720, Mission San José y San Miguel de Aguayo was established south of San Antonio de Valero on the bank of the San Antonio River. The foundation documents do not make it clear which side of the river was selected for the site, but subsequent documents indicate that it was the east bank. For example, Fr. Isidro de Espinosa, writing ca. 1744, states that since its foundation San José had been moved from its original site to the other side of the river and further downstream (Espinosa 1964:758). Since the mission was known to be on the west bank and at its present location in 1744, this indicates that the original site was on the east bank and somewhat closer to San Antonio than the present site. The distance south of Valero for the location of the first site of San José is given as "a little more than three leagues," (Habig 1968:33) which would place it at about the location of Mission San Juan. However, the early distances are frequently erroneous, and cannot be considered a true indicator of San José's location. The mission was moved from its first site to the west side of the river within a few years, apparently by 1722 (see below), for unknown reasons (Habig 1968:84-86). San José was certainly on the west bank by 1727 (Habig 1968:86).

\section{The Second Occupation of the Site}

In 1722, the effort to establish a new mission to be called San Francisco Xavier de Nájera was begun. A site was selected one league (2.63 miles) south of Mission San Antonio de Valero (Mission Concepción is 2.14 miles south of Mission San Antonio de Valero's present site, which itself is within a quarter-mile of its presently unknown location as of 1722), and it was observed that water to irrigate the fields of this new mission could be obtained either from the Valero acequia system or directly from the San Antonio River (Castañeda 1936 Vol. 2:161). No reference was made in the several available documents concerning the establishment of Nájera to indicate that it was bordering San José in any way. This new mission was abandoned ca. 1726 because of a lack of interest in a separate mission on the part of the Indians for whom it was intended. They elected instead to become part of Valero's neophyte population. By the time of Paredes'visita in 1727 , the Nájera attempt was forgotten.

When Mission Concepción was established five years later, the documents of foundation state explicitly:

“ . . en dicho paraje, para la subplantacion de la mision exprexada [Mission Concepción], que tenia de su principio por abvocacion San Francisco Xabier de Nagera, aplicado a los Yndios Yerbipiamos, agregados ay a la Mision de San Antonio, y estar despoblado, y exempto de contradicion por perzona alguna . .." (" . . in the said place for the establishment of the mission stated [Mission Concepción], which was first used for the advocation of San Francisco Xavier de Najera, requested by the Hierbipiame Indians, who have congregated at the Mission San Antonio, and [the place] is abandoned, and exempt from contradiction by any person . . ." (Almazán, 1731:20). 
This leaves little doubt that the site selected for Mission Concepción was physically the same as that selected previously for Mission San Francisco Xavier de Nájera. San José's earlier presence in the area is apparently not mentioned because San José had moved prior to Nájera's establishment. Nájera was therefore the only possible source of conflict with Concepción and no reference to San José would have been necessary.

As is indicated in the Investigations and Artifacts sections above, there is good reason to believe that traces of Mission San José's first site were located by both the present investigation and that which was conducted in 1971-1972 by the THC. So far these traces consist only of two probable early acequias (or two sections of the same acequia, Blocks VI, XII), one of which contains artifacts dating to the 1720-1730 period (Block XII). Since the San Francisco Xavier de Nájera site apparently never had any structures built for it, and since the artifact contents strongly suggest that the acequialike feature and its artifactual material were produced by an occupation of the site before 1730 , little choice is left but to conclude that this occupation was indeed that of Mission San José y San Miguel de Aguayo. It appears that the acequia was abandoned when San José left the site, and it was unused or rerouted during the occupation of Najjera. However, with so little archaeological information and not much more historical evidence, this suggestion about the early occupations of the site of Mission Concepción must be considered a hypothesis to be tested in the future.

\section{The Third Occupation of the Site}

The siting of Mission Concepción in this location in 1731 , only five years after the Nájera attempt was abandoned, may have been determined by the presence of an extant acequia system surviving from San José's occupation. By 1731 the system would have been in need of considerable repair and cleaning, but this would have been easier than the complete excavation of a new acequia. Again, it should be noted that the archaeological and historical information is so sparse that this remains hypothetical. Nonetheless, the very limited sample of this early period produced by the archeology certainly implies something along these lines; more archaeological work is necessary to investigate the early occupation in the west wall and south wall areas. The new mission of Concepción was situated so that the acequia ran through the middle of the pueblo. This acequia line has not been located by archeology, but deed records and maps indicate that the desagüe of the final plan of the mission may have crossed some part of the first plan. An alternate possibility is that the early acequia seen in Blocks VI and XII was the acequia which crossed the compound in 1745; this, however, makes it very difficult to explain the pre-1730 artifact content of this early acequia.

Construction of the first pueblo may have begun by 1732 , and by 1745 it consisted of a stone wall around the mission complex, a stone granary, three stone houses for a protective garrison of soldiers stationed here, and Indian quarters of jacal. Again, depending on the level of survival, some of these structures may have been built on the site by Mission San José a decade before. The foundations of the stone church were probably laid by ca. 1735 . While it was being built, services were held in an adobe building: "Serving now as the church is a room of adobe with a flat earthen roof, and with its sacristy" "Visita de las Missiones hecha, de N.M.P. Commo Gral, Fr. Juan Fogueras, por el P. Fr. Franco Xavier Ortiz, en el año de 1745." Roll 9, frames 1265-1285, October 11, 1745, Microfilm Archive, Old Spanish Missions Historical Research Library, Our Lady of the Lake University. San Antonio [OSMHRL]). During this same period, the missionaries lived in the first stone convento: "The missionaries live in a house of stone, which contains two stories; on the first they have two offices and on the second is actually where they live" (OSMHRL 9:1272). By 1756 this first stone convento was partly in ruins, and the present convento buildings were being constructed (Ortiz 1955:35).

First Church and Convento

Traces of this first church and convento have been found in several excavations since 1930. Harvey P. Smith, in excavations conducted in 1933, located the foundations of the first stone convento south of the present convento structure and extending under the present parking lot east of Mission Road 
(Ivey 1982:13). The THC excavations of 1971 confirmed Smith's discoveries and found more traces of the foundations in their units 59 and 61 . In the present excavations, additional foundations were found in Blocks I and XIII. The burials in Units 22 and 25 of Block XIII, in conjunction with the adobe walls found in Unit 33 and in the THC excavations, argue that the structure for which these walls were built was the adobe church in use from $1735-1740$ to 1755 . This structure had walls $2.78 \mathrm{ft}$ thick, a white-plastered interior, and several layers of white to light tan-puddled adobe floor, through which the graves were dug at various times. Excavations in the summer of 1982 by the NPS showed that this structure was $14.9 \mathrm{ft}$ wide and $60.6 \mathrm{ft}$ long, and all its characteristics correspond to that of the church described by Ortiz in 1745 and Ivey (1982:18). The adobe foundations seen in Block I are for some small structure which predates the first stone convento and may be traces of an earlier adobe convento. Their presence hints that the adobe church had an associated adobe convento, which was torn down and replaced by a stone convento before 1745 . Other structures and features which may be from this period are 1) the stone wall on a yellow gravel and sand foundation seen in Block VII which may have been the original stone wall built around the mission, mentioned in the inventory of $1745 ; 2$ ) the early stone wall in Block $\mathrm{I}$, which was disturbed by the later foundation of the granary and which was probably a part of the first stone convento attached to the adobe church; and 3) the trash pit found in Block VI (which dates from the 1730s) near the possible compound wall of Block VII and perhaps near a gate through this wall.

Various parts of this complex were built at different times. The present church was begun ca.1735-40 and completed in 1755 (Habig 1968:131). The friary adjoining it was the second convento. It was begun in ca. 1750 and was almost finished by 1756 (Ortiz 1955:35). The workrooms associated with the friary were built during the same period.

An examination of the standing parts of these buildings and the foundations located in the ground by the WPA and the THC permits several inferences about the sequence of events involved in their construction.
The original plan of the convento, as rebuilt beginning in the early 1750 s, appears to have been a row of cells and offices with an arcaded corridor on each side and vaulted ceilings. This strongly resembles the open convento plan in use in the California missions, which were founded after 1769. This plan strongly contrasts with the layout of the convento at San Antonio de Valero, for example, which was begun ca. 1724. The Valero convento follows the pattern of those built in New Mexico, ca. 1620-1700.

The differences in these plans are not trivial. They reflect a large change in the philosophy of the relationship between the friar and the Indian community he served in the mission. The New Mexico conventos were enclosed squares facing inward on a patio, effectively turning their backs on the active life of the Indian pueblos nearby. The daily business of mission life was handled through the porteria, an official formal entrance or foyer of the convento, which was similar to a waiting room, with benches along the walls (Kubler 1940:21, 35, 74). The California convento was open, facing towards the Indian pueblo or outward onto the surrounding fields of the mission (Johnson $1964: 53,65,145)$.

The San Antonio missions were under construction during the period from 1724-1782 and reflect this change in philosophy. San Antonio de Valero, the earliest, replicates the New Mexico pattern; Espada and San Juan were begun on a New Mexico plan ca. 1735 and converted to an open convento with a California appearance ca. 1780. San José's original convento plan is unknown, but was an open convento by 1785 and perhaps somewhat earlier. The very limited available evidence implies that the abandonment of the enclosed cloister pattern for missions occurred ca. 1740.

Work on the present convento was still continuing in 1756 when it was first described, and was nearing completion in 1759: "De el convento se hallan fabricadas algunas piesas, para la havitacion de los Ministros, oficina, obraje, y otras; aunque no se ha concluido su obra, esta es de piedra, y hasta aora lo mas de bobeda, lo que parece no probar bien, por lo que se ha mandado prosiga de vigueria ... (Various rooms of the convento have 
been built, [one] for the residence of the Ministers, office, weaving room, and others; although its construction has not been finished, it is of stone, and up until now mostly vaulted, which proved to be unsuitable, for which reason it has been ordered to proceed with a roofing of beams) (Testimonio de la Visita de las Missiones de las Proas de Coahuila, y Texas pertenecientes al Colegio de la Santa Cruz; echa por el R. P. Fr. Mariano Franco de los Dolores y Biana, Como Visitador de todas ellas en el mes de Marzo de 1759." May 20, 1759. Microfilm Archives 9:1493. Old Spanish Missions Historical Research Library. Our Lady of the Lake University, San Antonio [OSMRL]). The new convento was probably intended eventually to contain all the workrooms and offices in its new plan. It extended southward from the south bell tower of the new church to the walls of the first stone convento. The work was apparently stopped at this point, although several lines of foundations continued to the south across the first stone convento foundations. The phrasing of the Report of 1759 leads us to this hypothesis: the portions of the present stone convento standing in 1772 were all completed soon after 1756 . The eastern half of the first stone convento was then torn down and new foundations constructed across its old foundations, in preparation to extend the building further south. The order referred to in 1759 came through and stopped all further construction of the vaulted buildings planned; all buildings built after 1759 had flat earthen roofs. This indicates that the extension of the vaulted convento to the west. The rooms which were the cocina, or kitchen, in 1772 (Figure 3; OSMHRL Sáenz de Gumiel 1772, $10: 4254$ ), which were obviously added to the corredor after its completion, had to have been built between 1756 and 1759 . The presence of the corn-cob pit in Block I, apparently within a room of the early convento, implies that the present convento buildings went into use and the earlier convento left abandoned for a brief time before its demolition, since this pit is most likely to be associated with an Indian cooking process of some sort rather than one used regularly by the missionaries. In other words, the missionaries moved out of the older convento buildings and into the new ones ca. 1756, and while the old buildings stood vacant, 1756-1759, parts of it were used for cooking activities, at the least, by mission Indians.
By 1772 the completed portion of the eastern arcade had been converted to a guest room and its entrance corridor. One archway had been filled to make one wall of the room and a wall with a door built across the corridor to close the room off from the entrance way. The south end of the western corridor had been enclosed and converted to a refectory by filling in the southernmost arch with a small window through the filled arch, looking west (Scurlock and Fox 1977:Figure 3).

Changes in the convento buildings after 1772 are undocumented until 1824-1860. During this last period, the convento was used or rented to others as a residence by Ramón Músquiz, the political chief of Béxar from 1827-1835 and Governor of Texas and Coahuila from 1835-1836 (Webb 1952 Vol. 2:253). Músquiz described these rooms in his deed of transfer (Appendix I, No. 1). When Músquiz owned the convento (Figure 2) the western arcade served as a porch, the three main cells were "a saloon (salon) with an adjoining room and gallery," and in the eastern arcade the corridor to the guest room had had its arch filled. It and the guest room were then converted to a kitchen: "a porch on the east of eighteen (18) varas [50 ft] with two arches closed to form a kitchen" (BCDR Vol. S1:480, Oct. 23, 1860). The phrasing of this deed would appear to have been taken from the original Spanish deed of 1824 . The cocina of 1772 was not mentioned in the Músquiz deed, which indicates that it had fallen by 1824 .

Bishop John Mary Odin, who purchased the convento from Músquiz in 1860 , transferred the property to the Brothers of Mary who had been using some part of the land belonging to the mission since 1855 (Schmitz 1965:26).

The church was reopened in May 1861. From 1861 until 1866, the mission was used for the training of candidates for the Order of the Brothers of Mary. After this training program was closed, a few brothers lived at the mission and farmed the land until 1869. From 1869 until 1911, most of the land belonging to the mission (probably the fields west of Mission Road) were leased to private farmers, and the convento buildings were used as summer houses and retreats for the brothers (Schmitz 1965:27-28). 
During these years, the arches of the western arcade were filled and the corredor converted to rooms. The arches were reopened by 1934 (Scurlock and Fox 1977:15).

\section{Workshops and Granary}

The structural history of the workrooms at Concepción is less clear. These are usually given less detailed attention structurally than the explicitly religious buildings in the inventories, and therefore changes in plan and location are very difficult to recognize. In 1772 the Inventory indicates that a forge and a carpenter's shop of stone had been built somewhere along the south side of the convento, but the sizes of these structures do not match those of any of the known surviving rooms or archaeological traces.

The construction period for the granary is equally ambiguous. There was a stone granary at the mission by 1745 , and a stone granary is mentioned in 1756 and 1772 . If these were all the same structure, then the granary was probably begun ca. 1735 , about the same time as the church, and completed by 1745 . The probable layout of the granary is shown in Figure 3. The rooms at the south end of the granary apparently overlap the earlier convento rooms, and therefore must have been begun some time after the demolition of the first stone convento in 1759 . Since the inventory of 1772 does not describe any structures in this area at the time, it is likely that the rooms were built after 1772 and before 1838, when they were first described in the deed wherein Manuel Yturri y Castillo sold the granary to Asa Mitchell (see below).

At the time of secularization in 1794, the granary roof was in need of repair because it was leaking (BCA-MR 28). In February 1806, José Antonio Huizar, the Spanish alcalde of the combined missions of Concepción and San José, petitioned to be granted possession of the granary at Concepción. He stated that it was partly in ruins and that he would rebuild it for a dwelling. This property was granted to him in March 1806 (BCAMR 70).

In 1815 Huizar re-petitioned the government. He explained that a series of events had prevented his receiving full title to the granary at Concepción. One of these events was the abandonment of the mission ca. 1810. Because of this, he said, he wished to change his petition and asked instead for the granary building at Mission San José. The change was accepted, and he received full title to this property in 1815 (BCA-MR 70, 71). The Concepción granary was finally granted to Manuel Yturri y Castillo in 1823 (BCDR Vol. A2:77, Nov. $5,1823)$. Yturri y Castillo may have done some reconstruction on the granary; by 1838 , when he sold the building to Asa Mitchell, the granary and the rooms on its south end were described as "three rooms, built of stone, and connected together in a row, which adjoins the said church at its South east corner" (BCDR Vol. A2:74, Aug. 1838). In 1849, when this tract was surveyed, some portion of the granary was still standing: " . . to the S. W. corner of an old house formerly occupied by Yturri; Thence $\mathrm{N} 5^{\circ} \mathrm{E}$ along the West wall of said house 32 varas to where said house joins the Concepción Mission . . ." ( BCDR Vol. Pl:619, March 16, 1849). The actual date of collapse of the granary is not known, but drawings made in the 1850 s indicate that it had fallen by that decade. For example, a drawing by Lungkwitz in 1851 shows only low, ruined walls in this area (Pinckney 1967:87), as does a Pentenrider drawing printed in 1856 (Pinckney 1967:150). Since it is unlikely that this much collapse occurred between 1849 and 1851 , we should probably assume that the building was already in ruins by 1849 , and that the surveyor simply did not see fit to mention this. An approximate date of collapse of ca. 1845 is, therefore, reasonable.

Evidence of stone robbing of the foundation indicates that the fallen stone and surviving wall fragments were used as building material for new structures in the area, as was so much of the Concepción rubble. By 1890 evidence of the presence of the foundation had been so thoroughly removed that Corner (1890:16) gave no indications of them on his plan of Concepción, even though he shows the foundations of other walls which had long since fallen by that year.

In 1934 traces of the foundation were noted by Smith during the WPA excavations. By the 1960 s a restroom had been built in the middle of the granary remains, which damaged some of the 
foundations. A mound is still clearly visible today, indicating the approximate outlines of the granary foundations.

\section{The Pueblo}

The pueblo containing the Indian quarters was begun on the present plan soon after 1756 (Ortiz 1955:35). By 1759 the enclosure shown in Figure 3 was completed, and two sides of it (probably the east and west sides) had a continuous row of Indian houses of stone and jacal (OSMHRL 9:1493-94, May 20, 1759). In 1772, 24 houses had been finished in stone, filling the east, north and west sides of the pueblo. Two more were in the last stages of construction, and the inventory remarked that in the same row as these two under construction, there was space for six more houses (OSMHRL 10:4254). These last houses were probably along the south wall of the pueblo.

There are some indications that the pueblo was laid out, and the main lines of wall foundation built, before any further above-ground construction occurred. In fact, the broad pavement-like lines of travertine and adobe seen in Blocks VIII, IX, XI, and XII may have been intended as the original outlines of the main wall of the pueblo, a plan which was not faithfully followed in later constructions. Most of the Indian quarters were built against the outside of this wall line.

The same method of complete plan foundation construction was probably followed in the construction of the convento. Even lines of arcade structures may have had continuous subsurface foundations, rather than a series of blocks intended as the base of each arch. The full-sized church at Espada, for example, was outlined by foundations before any further work was begun (OSMHRL 15:4197-4198) Construction never got above ground on any part of this church except one wall of one transept, which forms the facade of the present Espada Chapel.

The Inventory of 1772 described Mission Concepción at its peak of development (OSMHRL 10:4235-4263). Apparently all construction on Indian quarters stopped about 1770 and was never continued.
In 1777, Fr. Juan Morfi (1935:226) described the pueblo of Concepción in his diary: "The houses of the Indians make an enclosed plaza with the house of the Ministers and the church."

In 1786 Fr. José Francisco López stated that the mission was encircled by a wall of stone and mud which was somewhat low in places. This wall had three gateways, one to the east, another to the west, and one to the south, with large doors of carved wood. One of the 24 houses standing in 1772 had fallen, and others were in a badly deteriorated condition (López 1786:2, 2 reverse). There were plans to repair these, but the movement to secularize the missions was well started by this date, and these plans were apparently never carried out.

Partial secularization was enacted in 1794. All the properties of the mission, except the church and sacristy, were turned over to the Indians. In the inventory of the secularization, the Indian quarters are described as follows: "Item: the said Indians received the houses in which they live, which are against the compound wall of stone with three gates, one with a postern-door, and all with their locks. The said wall, and various of the houses of the said Indians require repairs to those sections which have been damaged by water" (BCA-MR 28:18).

Few of the Indians continued to live in these houses after 1794. By 1823 and the final secularization of the mission (when the church and sacristy were released by the missionaries into the hands of the local Bishop), none of the original Indian families to which these houses were granted remained. Most of the mission properties were re-granted to new owners, but the Indian quarters were, by this date, in such bad repair that none were sold individually.

By 1857, the houses and walls of the pueblo had decayed to the point that they were no longer visible. The survey along the east and north walls in that year followed the old wall lines only generally, and probably are a record of nothing more than the tops of the rubble mounds and ridges marking the outline of the mission plaza (BCDR Vol. H2:250, Oct. 2, 1857). Stone robbing of various parts of the ruins, probably a long-standing activity, increased throughout the last half of the 
19th century, and the main line of Mission Road was moved to cross the plaza about 1890 (BCDR Vol. 54:85, May 14, 1887). Corner (1890:16) was not able to make more than a rough guess at the outlines of the mission pueblo.

\section{Mission Concepción in the Context of the Other San Antonio Missions}

It is apparent from this structural history that Mission Concepción was a viable, developing mission until about 1770; at that point, all of its building programs came to a halt. Little or no further development occurred after that year, and, in fact, the historical record indicates a slow but steady decay of the mission.

Such a change in attitude is reflected in other Queretaran missions of San Antonio. At Mission San Antonio de Valero, for example, the construction on the church had stopped by about 1770, and again only a history of deterioration can be found afterwards (OSMHRL, 4:5808; Leutenegger 1977b:7). At Espada the new church had been begun by 1762 , but had not progressed beyond the base foundations by the time of the transfer of responsibility from Querétaro to Zacatecas and was apparently never completed (OSMHRL 15:4197-4198).

Only at mission San Juan is there any indication of new religious construction after 1772 ; a new church had apparently been begun between 1772 and 1779 , but was still only half built by 1786 (Schuetz 1968:217; López 1786:5) and was never completed. In contrast to this, the construction of the church at Mission San José, the Zacatecan mission in San Antonio, continued and was completed about 1780 . Other major construction at San José was also carried out during the years from 1772 to 1794 , when partial secularization was enacted.

It should be noted, however, that the pueblos of both Mission San Juan and Mission Espada were extended to the east in about 1780. Espada had a number of new houses built along the south and east walls of this extension, and a few new houses were also added at San Juan.
Outside the missions proper, additional construction occurred other than at Mission San José. For example, it would appear that about the same time that the mill at Mission San José was being built (ca. 1790), a similar mill was built north of Mission Concepción on the east bank of the San Antonio River, perhaps part of a program to supply grist mills to the several mission communities (Appendix Ia). The buildings at Rancho de las Cabras of Mission Espada were almost completely rebuilt and new defensive structures added (Ivey 1983:35-39).

From these observations and many other comparisons that could be made between Mission San José and the ex-Queretaran missions, we hypothesize that the transfer of Mission Concepción and the other three Queretaran missions from the Franciscan Missionary College of Querétaro to that of Zacatecas in 1772 resulted in the cessation of almost all work on the religious structures of these missions. Work on the church of Mission San José, which had always been Zacatecan, continued. This would seem to imply a new policy on the part of the Zacatecan missionaries. This policy seems to have been one of preparing the missions for a more secular life, and may have been instituted in anticipation of secularization. The first recorded move in the direction of secularization was the decision by the governing council of the College of Zacatecas to petition the Viceroy to assume responsibility for the temporalities of the Texas missions, enacted in January of 1780 (Leutenegger 1973:31). This corresponds well with the estimated dates of the extensions to missions San Juan and Espada. Such a policy has far-reaching implications for the Zacatecan missions of Texas, and should be the subject of further research.

\section{Recommendations}

As with all the San Antonio River Valley missions, the history of Mission Concepción, of its life and times, changes and traditions, is still relatively unknown in any detail. For example, the material Habig used to write his description of Concepción's history consisted primarily of four inventories and three brief descriptions. Since he wrote The Alamo Chain of Missions in 1968, two other texts 
specifically useful for the study of the history of Concepción have been printed or are available in transcript-the Inventory of 1772 , being prepared for publication by the Texas Historical Commission, and Guidelines for a Texas Mission, (Leutenegger 1976) - and the Old Spanish Mission Historical Research Library microfilms contain many other new sources of information on this and the other San Antonio missions. A strong program of historical research using these new resources should be conducted to improve this knowledge, concentrating on the periods from 1731-1745 and 1772-1794.

Such a low level of detailed knowledge about a place makes the task of interpretation very difficult. All phases of the growth and change of Mission Concepción are important to its interpretation to the public, not just those that have left visible remains. As a result of archaeology most of the permanent stone structures of Concepción have now been located, and much more is known about Mission Concepción's original plan and its development than that of the other missions; but this is only a relative increase in such knowledge. The actual plan of the first mission on the site of Concepción cannot yet be drawn; without it, no effective understanding of the physical changes through time that Concepcion has undergone can be reached. It is strongly recommended that further excavations be conducted to determine this first mission plan.

One of the purposes of the present excavations was to determine the limits of the core physical structure of the mission. It should be emphasized that although the south wall of the later pueblo built after 1756 has been located with a relatively high level of certainty, this wall line is not the southern limits of the site. The first convento complex extended at least $200 \mathrm{ft}$ farther south down the line of Mission Road, perhaps as far as the intersection of Felisa Street and the present line of Mission Road (Figure 3; Appendix I, No. 7). The area of the Blessed Sacrament Convent probably contains some part of this first mission, and certainly a fair portion survives beneath the paving of the Concepción parking lot south of the church and convento. These considerations should be taken into account during the final planning of property acquisition for Concepción. A similar situation could exist for the other missions, and an intensive land-use research program, like that of this investigation, should be conducted for each mission before finalization of acquisition plans. In addition, such studies are necessary to avoid placing parking lots, pipelines, restroom facilities, and other such developmental structures on critical historical or cultural resource areas. Effective ground planning which gives proper respect to the hidden resources of each mission is impossible without such a research program. This point cannot be emphasized too strongly.

The proposed relocation of Mission Road, returning it to its colonial alignment, is essential to an effective presentation of Mission Concepción. The present alignment of the road destroys any possibility of presenting Mission Concepción as the well-defined, patterned complex which dictated the life of the mission. If the road is moved, the safest place to move it is to its original line. The features containing artifacts predating 1730 found by the very limited testing in this area indicate that even this old road line may run across parts of the undefined 1720 s occupation and would therefore have to be tested archaeologically with great care. Regardless of what this occupation was, it has to be of great significance to the history of the development of the San Antonio area, and should be treated with extreme caution.

Looking ahead to the development of the interpretive aspects of Mission Concepción, the surviving subsurface structural remains of the pueblo walls, the Indian quarters against them, and the foundations of the first mission buildings should be briefly assessed. Virtually all of the west and south walls have been destroyed or so severely disturbed that only two or three inches of their original depth survives. No effective display of the actual fabric of the wall is possible, and a surface indication of their presence and plan is all that should be considered, short of actual restoration.

On the east wall, the first $100 \mathrm{ft}$ of walls and rooms south from the northeastern corner are probably still present in substantial form; another 50 to 100 $\mathrm{ft}$ may also survive. On the north wall, again the first $100 \mathrm{ft}$ of walls and rooms may survive extending west from the northeastern corner. In both cases, however, these foundations consist of a fragile soft travertine limestone and even more 
fragile adobe mortar and bricks. There are no known inexpensive methods of exposing such structural remains to weather and park visitors with any hope of their survival. Again, marking their plan on the ground surface might be the best presentation method. A small building constructed over a well-preserved section of wall, which could be completely excavated and left exposed within view inside the building, might be considered.

The first mission structures, underlying the present structures as they do, present even greater difficulties for the presentation of their physical realities. Large-scale models and plan drawings of the various stages of the history of the mission might be preferable to an attempt to display the physical remains themselves. However, such models and plans are not feasible without further archaeology.
Other details that should be considered for future planning are the mill north of the mission, which is probably part of the mission "physical plant," and the acequia system, at least insofar as it crossed the mission park grounds. Archaeological tracing of the several acequia lines located by research and excavations should be considered. Whether anything should be done about the mill by the National Park Service (since at present it is not on the planned grounds for the park) is a different problem; its solution is beyond the limits of this investigation.

Mission Concepción has demonstrated itself to be a far more complex and changeable entity than anticipated. This very complexity should insure that with proper development it will be of great interest to future visitors to the missions of San Antonio. More importantly, future research into the history and archaeology of the mission will be of great importance to our understanding of how and why missions in San Antonio developed as they did. 


\section{References Cited}

Almazán, J. A. P. de

1731 Autos de Possession de las Misiones ... March 5, 1731. Missions in Texas, Vol. 50, pp.19rev.-23rev. Spanish Archives. Texas General Land Office, Austin.

Barnes, M. R. and R. V. May

1972 Mexican Majolica in Northern New Spain. Occasional Paper, No. 2. Pacific Coast Archaeological Society, Costa Mesa, California.

Brown, M. J., A. A. Fox, and B. A. Meissner

1993 Archaeological Testing for the Mission Road Re-alignment Project, Phase II, at Mission Concepción, San Antonio, Texas. Archaeological Survey Report, No. 222, Center for Archaeological Research, The University of Texas at San Antonio.

Calhoun, C. A.

1968 Tin-Enameled Earthenwares. Manuscript on file; Center for Archaeological Research, The University of Texas at San Antonio.

Castañeda, C. E.

1936 Our Catholic Heritage in Texas. Vol. 2. Von Boeckman-Jones, Austin.

1942 Our Catholic Heritage in Texas. Vol. 5. Von Boeckman-Jones, Austin.

Corner, W. (compiler and editor)

1890 San Antonio de Béxar: A Guide and History. Bainbridge and Corner, San Antonio.

Deetz, J. F.

1978 Archaeological Investigation at La Purisima Mission. In Historical Archaeology: A Guide to Substantive and Theoretical Contributions, edited by R. L. Schuyler, pp. 160-190. Baywood Publishing Company, Inc., Farmingdale, New York.

Dolores y Viana, Fr. M. F. de los

1961 Relación del Estado en que se hallan todas y cada una de las misiones, en el año de 1762. In Documentos Para la Historia Eclesiástica y Civil de la Provincia de Texas o Nueva Philipinas 1720-1779, edited by J. P. Turanzas, pp. 245-275. Colección Chimalistic de Libros y Documentos Acerca de la Nueva España, Vol. 12. Ediciones José Purrúa, Madrid.

Espinosa, I. F. de

1964 Crónica de los Colegios de Propaganda Fide de la Nueva España. Edited by L. Gómez. Canedo. Academy of American Franciscan History, Washington, D. C..

Fox, A. A.

1977 The Archaeology and History of the Spanish Governor's Palace Park. Archaeological Survey Report, No. 31. Center for Archaeological Research, The University of Texas at San Antonio.

1988 Archaeological Excavations at Mission Concepción, Fall of 1986. Archaeological Survey Report, No. 172. Center for Archaeological Research, The University of Texas at San Antonio.

1989 Monitoring of Utility Trenches at Mission Concepción, San Antonio, Texas, 1988. Archaeological Survey Report, No. 180. Center for Archaeological Research, The University of Texas at San Antonio. 
1992 Archaeological Investigation to Locate the Northwest Corner of Mission Concepción, San Antonio. Archaeological Survey Report, No. 212, Center for Archaeological Research, The University of Texas at San Antonio

Fox, A. A., F. A. Bass, and T. R. Hester

1976 The Archaeology and History of Alamo Plaza. Archaeological Survey Report, No. 16. Center for Archaeological Research, The University of Texas at San Antonio.

Fox, A. A. and J. E. Ivey

1997 Archaeological and Historical Investigations at Alamo Historical Park, San Antonio, Texas. Archaeological Survey Report, No. 120. Center for Archaeological Research, The University of Texas at San Antonio.

Fox, D. E.

1979 The Lithic Artifacts of Indians at the Spanish Colonial Missions, San Antonio, Texas. Special Report, No. 8. Center for Archaeological Research, The University of Texas at San Antonio.

Gerald, R.

1968 Spanish Presidios of the Late Eighteenth Century in Northern New Spain. Research Records. No. 7. Museum of New Mexico.

Gilmore, K. K.

1969 The San Xavier Missions; A Study on Historical Site Identification. Archeological Program, Report 16. State Building Commission, Austin.

1974 Mission Rosario, Archeological Investigations 1973. Archeological Report, No. 14, Part 1. Texas Parks and Wildlife Department, Historic Sites and Restoration Branch, Austin.

1975 Mission Rosario, Archeological Investigations 1974. Archeological Report 14, Part 2. Texas Parks and Wildlife Department, Historic Sites and Restoration Branch, Austin.

Goggin, J. M.

1964 The Spanish Olive Jar. In Indian and Spanish Selected Writings. University of Miami Press, Coral Gables, Florida.

1968 Spanish Majolica in the New World. Yale University Publications in Anthropology, No. 72. Yale University Press, New Haven.

Greer, J. W.

1967 A Description of the Stratigraphy, Features, and Artifacts from an Archeological Excavation at the Alamo. Archeological Program Report, No. 3. State Building Commission, Austin.

Habig, M. A.

1968 The Alamo Chain of Missions, A History of San Antonio's Five Old Missions. Franciscan Herald Press, Chicago.

Hester, T. R.

1978 "The Material Culture at Missions San Juan Bautista and San Bernardo." Paper presented to the Society for Historical Archaeology Annual Meeting, January 1978. On file; Center for Archaeological Research, The University of Texas at San Antonio. 
Ivey, J. E.

1983 Archaeological Testing at Rancho de las Cabras, Wilson County, Texas. Second Season. Archaeological Survey Report, No. 121. Center for Archaeological Research, The University of Texas at San Antonio.

Ivey, J. E. and A. A. Fox

1981 Archaeological Survey and Testing at Rancho De Las Cabras, Wilson County, Texas. Archaeological Survey Report 104. Center for Archaeological Research, The University of Texas at San Antonio.

Ivey, J. E., M. B. Thurber, and S. Escobedo

1990 Of Various Magnificence: The Architectural History of the San Antonio Missions in the Colonial Period and the Nineteenth Century, Vol. 1 of An Architectural and Administrative History of the San Antonio Missions in Two Volumes. Professional Papers, No. 11. Southwest Regional Office, National Park Service, Santa Fe, New Mexico. (Draft)

Johnson, P. C., ed.

1964 The California Missions: A Pictorial History. Lane Book Company, Menlo Park, California.

Kendall, D. S. and C. Perry

1974 Gentilz, Artist of the Old Southwest. University of Texas Press, Austin.

Krueger, M. And F. Meskill

1992 Test Excavations at Mission Concepción Courtyard, San Antonio, Bexar County, Texas. Archaeological Survey Report, No. 180. Center for Archaeological Research, The University of Texas at San Antonio.

Kubler, G.

1940 The Religious Architecture of New Mexico in the Colonial Period and Since the American Occupation. School of American Research. University of New Mexico Press, Santa Fe.

Labadie, J. H.

1989 Archaeological and Historical Investigations for the Mission Road Realignment Project. Archaeological Survey Report, No. 173. Center for Archaeological Research, The University of Texas at San Antonio.

Leighton, Jennifer S.

1973 Photography of Glass Artifacts from Historic Sites: a Useful Technique. Historical Archaeology, 8:78-80. Society for Historical Archaeology. Lansing, Michigan.

Leutenegger, Fr. B.

1973 The Zacatecan Missionaries in Texas, 1716-1834; Excerpts from the Libros de los Decretos of the Missionary College of Zacatecas, 1701-1828. Texas Historical Survey Committee, Report No. 23. Office of the State Archeologist, Austin.

1976 Guidelines for a Texas Mission: Instructions for the Missionary of Mission Concepción in San Antonio. Documentary Series, No. 1. Old Spanish Missions Historical Research Library, Our Lady of the Lake University, San Antonio.

1977a Management of the Missions in Texas: Fr. José Rafael Oliva's Views Concerning the Problem of the Temporalities in 1788. Documentary Series, No. 2. Old Spanish Missions Historical Research Library, Our Lady of the Lake University, San Antonio. 
1977b Inventory of the Mission San Antonio de Valero: 1772. Special Report, No. 23. Texas Historical Commission, Office of the State Archeologist, Austin.

1981 Letters and Memorials of the Father Presidente Fray Benito Fernandez de Santa Ana, 1736-1754. Documentary Series, No. 6. Old Spanish Missions Historical Research Library, Our Lady of the Lake University, San Antonio.

Leutenegger, Fr. B. and Fr. M. Habig

1978 The San José Papers, The Primary Sources for the History of Mission San José y San Miguel de Aguayo From Its Founding in 1720 to the Present. Part I: 1719-1791. Old Spanish Missions Historical Research Library at San José Mission, San Antonio.

Lister, F. C. and R. H. Lister

1974 Majolica in Colonial Spanish America. Historical Archaeology 8:17-52.

1976 Distribution of Mexican Majolica along the Northern Borderlands. In Collected Papers in Honor of Marjorie Ferguson Lambert. Papers of the Archaeological Society of New Mexico No. 3. Albuquerque.

1982 Sixteenth Century Majolica Pottery in the Valley of Mexico. University of Arizona Press, Anthropological Papers of the University of Arizona, 39. Tucson.

López, Fr. J. F.

1786 Razon y Ynforme . . May 5, 1786. Copy made by Fr. Josef Sanchez de Luque on November 28, 1789, from the original in the Archivo de la Secretaria Episcopal in the city of Monterrey, Mexico. Photostat in the Center for American History, The University of Texas at Austin.

Matson, D. S. and B. L. Fontana, eds. and translators

1977 Friar Bringas Reports to the King: Methods of Indoctrination on the Frontier of New Spain, 1796-97. The University of Arizona Press, Tucson.

Morfi, Fr. J. A.

1935 Viaje de Indios y Diario del Nuevo México. Con una introducción biobibliográfica y Acotaciones por Vito Alessio Robles. Segunda edición con adiciones de la impresa por la Sociedad "Bibliófilos Mexicanos." José Porrúa e Hijos, México.

Mounger, M. A.

1959 Mission Espiritu Santo of Coastal Texas: An Example of Historic Site Archeology. M.A. thesis, The University of Texas at Austin.

Noël Hume, I.

1970 A Guide to Artifacts of Colonial America. Knopf, New York.

Ortiz, Fr. F. X.

1955 Razón de la Visita a las Misiones de la Provincia de Texas. Vargas Rea, editor. Biblioteca de Historiadores Mexicanos. Mexico.

Pinckney, P. A.

1976 Painting in Texas: The Nineteenth Century. Amon Carter Museum of Western Art, Fort Worth. Printed by University of Texas Press, Austin.

Schmitz, J. W.

1965 Mission Concepción. Texian Press, Waco, Texas. 
Schuetz, M. K.

1968 The History and Archeology of Mission San Juan Capistrano, San Antonio, Texas (Vol. 1). Historical Documentation and Description of the Structures. Archeology Program Report, No. 10. State Building Commission, Austin.

1969 The History and Archeology of Mission San Juan Capistrano, San Antonio, Texas (Vol. 2). Description of the Artifacts and Ethnohistory of the Coahuiltecan Indians. Archeology Program Report, No. 11. State Building Commission, Austin.

1980 The Indians of the San Antonio Missions, 1718-1821. Unpublished Ph.D. dissertation. The University of Texas at Austin.

Scurlock, D. and D. E. Fox

1977 An Archeological Investigation of Mission Concepción, San Antonio, Texas. Office of the State Archeologist Report 28. Austin.

Scurlock, D., A. Benavides, Jr., D. Isham, and J. W. Clark, Jr.

1976 An Archeological and Historical Survey of the Proposed Mission Parkway, San Antonio, Texas. Archeological Survey Report, No. 17. Office of the State Archeologist, Texas Historical Commission, Austin.

Secretario del Patrimonio Nacional

1975 Vocabulario Arquitectónico Ilustrado. Mexico.

Sevillano de Paredes, Fr. M.

1727 Visita de las Misiones del Río Grande del Norte por Fr. Miguel Sevillano de Paredes en 15 de Octubre 1727. Archivo General de México: Historia. Vol. 29, pp. 35-68. Typescript on file in Center for American History, The University of Texas at Austin.

Seifert, D.

1977 Archaeological Majolicas of the Rural Teotihuacan Valley, Mexico. Unpublished Ph.D. dissertation. University of Iowa, Ames.

Simmons, M. and F. Turley

1980 Southwestern Colonial Ironwork. Museum of New Mexico Press, Santa Fe.

Smith, H. G.

1965 Archaeological Excavations at Santa Rosa Pensacola. Notes in Anthropology, No. 10. Florida State University, Tallahassee.

Suhm, D. A. and E. B. Jelks

1962 Handbook of Texas Archeology: Type Descriptions. Special Publication, No. 1. Texas Archeological Society and Bulletin, No. 4. Texas Memorial Museum, Austin.

Taylor, F.B., R. B. Hailey, and D. L. Richmond

1966 Soil Survey of Bexar County, Texas. Soil Conservation Service, U.S. Department of Agriculture, Washington, D.C.

Tunnell, C. D.

1966 A Description of Enameled Earthenware from an Archeological Excavation at Mission San Antonio de Valero (the Alamo). Archeological Program Report, No. 2. State Building Commission, Austin. 
Tunnell, C. D. and J. R. Ambler

1967 Archeological Excavations at Presidio San Agustín de Ahumada. Archeological Program Report, No. 6. State Building Commission, Austin.

Tunnell, C. D. and W. W. Newcomb, Jr.

1969 A Lipan Apache Mission, San Lorenzo de la Santa Cruz, 1762-1771. Texas Memorial Museum Bulletin No.14. Austin.

Webb, W. P., ed.

1952 The Handbook of Texas. Texas State Historical Association, Austin. 


\section{Part III: Mission Parkway Survey Anne A. Fox}

\section{Introduction}

In September 1980, the Center for Archaeological Research (CAR) of The University of Texas at San Antonio entered into a contract with the National Park Service (NPS), Southwest Region, as an amendment to the Mission Concepción investigations, to perform archeological surveys of four proposed development areas and 13 remote-sensing anomalies within the San Antonio Missions National Historical Park. The resulting information was to be submitted to the NPS as soon as the survey was completed, with a final report to be appended to the Mission Concepción report. The purpose of the survey was to check for possible archeological sites in areas which might be impacted by park development in the vicinity of the missions, examine on the ground a number of anomalies identified on a series of aerial photographs taken for the NPS, to assess their origin and determine if any are of archeological or historical importance. Early in January 1981, additional anomalies and broad park areas were added to the list of survey work to be accomplished.

Survey in the future development areas and the anomalies was accomplished primarily during November 1980 . A report on the results of the survey of development areas was immediately sent to the NPS, Southwest Region. Most of the additional park areas and anomalies were surveyed in January 1981, and a report was submitted on this work. Due to pressure of other contracts, the remaining areas were not surveyed until November 1981. The following report is a summary of all the work done and an assessment of the areas surveyed and the archeological sites recorded.

\section{History of the Missions Park}

In 1720 , the Franciscan order established Mission San José y San Miguel de Aguayo on the San Antonio River south of the new settlement of San Antonio de Béxar. Eleven years later, missions Nuestra Señora de la Purísima Concepción de Acuña, San Juan Capistrano, and San Francisco de la Espada from east Texas were relocated at intervals downstream from San Antonio. The missions drew in Indians from all over south Texas and taught them the Spanish language, customs, and the Catholic religion in an attempt to make good Spanish citizens of them. Each mission built a system of acequias in order to enhance its ability to raise sufficient food to feed its inhabitants. Around the turn of the nineteenth century, as the missions were being secularized and their lands divided, numerous Spaniards and Anglo-Americans moved into the mission area and eventually into portions of the mission structures. They built mills on the river, and small settlements grew up around each mission composed of mission Indians' descendants and these new settlers.

Gradually, the mission structures deteriorated or were remodeled and converted to other uses. For the most part, only the churches retained their integrity and continued in sporadic use as parish churches. During the latter part of the nineteenth century, the inhabitants of San Antonio looked 
upon the missions as romantic ruins to visit on a family outing-a curiosity and nothing more. Even those who lived around these ruins had little thought for their origin or knowledge of their history.

In the early twentieth century, a few local citizens called public attention to the ruinous state of the mission churches. Attempts were made by individuals and the Catholic Church to stabilize and occasionally reconstruct collapsed structures. Then as public interest grew, a major project was launched in the 1930s, with the help of the Works Progress Administration (WPA), to locate buried walls and redelineate the mission structures. Mission San José was reconstructed and became a state park. The other three missions, the property of the Catholic Archdiocese of San Antonio, continued in use as parish churches and were gradually developed into tourist attractions. The concept of a Mission Parkway to connect and include the missions into a coordinated park system gradually evolved from the germ of an idea promoted by a few far-sighted individuals into its final culmination in the creation of the San Antonio Missions National Historical Park.

\section{Previous Archaeology Within The Park}

The first investigations done at the San Antonio missions were the work of WPA laborers under the direction of architect Harvey P. Smith, Sr., in the 1930s. At this time, many buried walls of the mission compound and structures were located, mapped, and selectively restored to a height of about three feet. In 1974, a comprehensive survey of the proposed Mission Parkway was carried out by the Office of the State Archeologist (Scurlock et al. 1976). The results of this survey have been most helpful in completing the present project.

Mission Espada has had a number of small-scale investigations planned to answer specific questions. Fox (Fox and Hester 1976) conducted test excavations at the base of the fortification tower at the southeast corner of the compound and recently in the area north of the chapel (Fox 1981). Also, in March 1977, Dan Scurlock of the Texas Historical Commission (THC) directed excavations at the lime kilns north of the mission walls (Killen and Scurlock 1978).

Mardith Schuetz $(1968,1969)$ directed extensive excavations in 1967, in advance of a program of remodeling and restoration at Mission San Juan. She also directed excavations within the San Juan chapel in 1969 prior to its restoration (Schuetz 1974) and of the original convento at the southwest corner of the mission compound in 1971 (Schuetz 1980). Scurlock (1976) conducted testing around the San Juan chapel in 1975.

Schuetz (1970) also monitored the sprinkler system trenches at Mission San José in 1968. Trenches dug for a sewer line in 1969 and an electrical line in 1970 were monitored by the author, and testing was done by D. E. Fox (1970) preparatory to the planting of a tree in 1970 . In 1974 and 1975, Clark (1978) conducted test excavations at various points on the mission grounds to examine foundations and soil profiles in connection with a program of research and soil testing. Also during 1974, Roberson (Medlin and Roberson 1976), conducted excavations in three rooms near the southwest corner, in advance of the remodeling of the area into offices and testing in the area of the entrance gate. The area west of the granary was tested in 1979 by Clark in advance of construction of a proposed drain (Clark and Prewitt 1979).

Other recent archeology at Mission Concepción in addition to the investigations reported by Ivey (Part II of this report) were directed by Scurlock in 1971 and 1972 (Scurlock and Fox 1977). This work is discussed in detail by Ivey in Part $\Pi$ and need only. be mentioned here.

\section{Methodology}

Surveys in November 1980 and January 1981 were conducted by Anne Fox and Betty Markey of the CAR staff; additional survey in November 1981 was done by Fox, Katherine Gonzalez, and Waynne Cox. The survey method was to walk over and directly examine as much of the designated area as possible or to survey transects of large heavily wooded areas at regular intervals. Also consulted were local informants, San Antonio River Authority staff members, archeological reports, 
historic maps, and aerial photographs. Survey teams followed out old acequia channels and wherever possible estimated where those ran that are no longer visible. Previously recorded archeological sites within the survey area were located and plotted on the project maps. In March, test excavations carried out at Mission Espada (Fox 1981) under a separate contract with the NPS, Southwest Region, yielded additional information, which has been helpful in interpreting anomalies surveyed under this contract.

It should be understood that there were a number of complications that may have influenced the accuracy of the survey. The terrain in many areas is densely overgrown, and there was often a thick cover of weeds or dead and decaying leaves on the surface, which hampered the search for artifactual evidence. The areas where this was a problem will be indicated. The nature and extreme age of parts of the acequia system, the total lack of information on the locations of laterals, and the habit of both Spanish and more recent irrigators of changing the location or direction of the ditches at will, often caused perplexing problems in understanding anomalies and identifying acequia courses. It is suggested that the present pattern of subsidiary acequias around the missions should not be unquestioningly accepted to be the original courses and that further study on this subject could be very interesting and rewarding. An additional problem in understanding what one sees in the area is the history of river channelization; this has caused major changes in the course of the river-and in the appearance of the lands on either side. In October 1957, the U.S. Army Corps of Engineers completed a channelization project on the San Antonio River south as far as the area just below Espada Dam, and this was extended in 1970 to a point south of Mission Espada (Dorian French, personal communication). An additional disturbance in the area, although minimal, was the re-excavation of the original course of the main San Juan acequia from its source to the Bergs Mill area in 1967 (Blair Warren, personal communication). A 1963 map by Williams-Stackhouse and Associates of the acequia system of San Juan used by the San Antonio River Authority (SARA) in this project has been of great help in locating the original river contours and the acequias and laterals on the east side of the river. This information has been incorporated into the project maps (Figures 20-24).

\section{The Survey}

Areas which may be affected by future development around each of the missions in the park were surveyed. Many of the anomalies to be investigated fell within these areas. In order to include all the assigned areas without becoming repetitious, each anomaly identified by aerial photography is dealt with briefly, observations of the development areas are then summarized, and finally the larger park area is discussed.

\section{The Anomalies}

The group of remote-sensing anomalies assigned for investigation in the fall of 1980 were designated by the letters' $a-n$. The letters $0-y$ were assigned to the anomalies surveyed in January 1981.

Area a appeared to be a deep trench along the face of a small hill, east of the San Antonio River (Figure 20).

This appears to be an acequia branch or a very old drainage channel. It is quite deep, with banks in places as high as 10 to $12 \mathrm{ft}$, and leads from the San Juan acequia downhill to the railroad tracks. It approaches the acequia, but at present does not tie in. Apparently, the local landowner has not used it for a long time and has extended the acequia beyond this point. There is no sign of historic or prehistoric occupation in the immediate area.

Area $\mathbf{b}$ appeared to be a linear depression and soil mark one quarter of a mile south of Loop 410, possibly affiliated with Areas $h$ and I (Figure 20).

No indication of this anomaly was found on the ground.

Area c appeared to consist of soil marks in modern fields west of Espada Road and south of the mission that are probably affiliated with acequias (Figure 20).

There was no sign of anything in this area on a 1942 aerial photo (No. 6S-13E-I) by Tobin Surveys, Inc. There is a modern irrigation canal to 


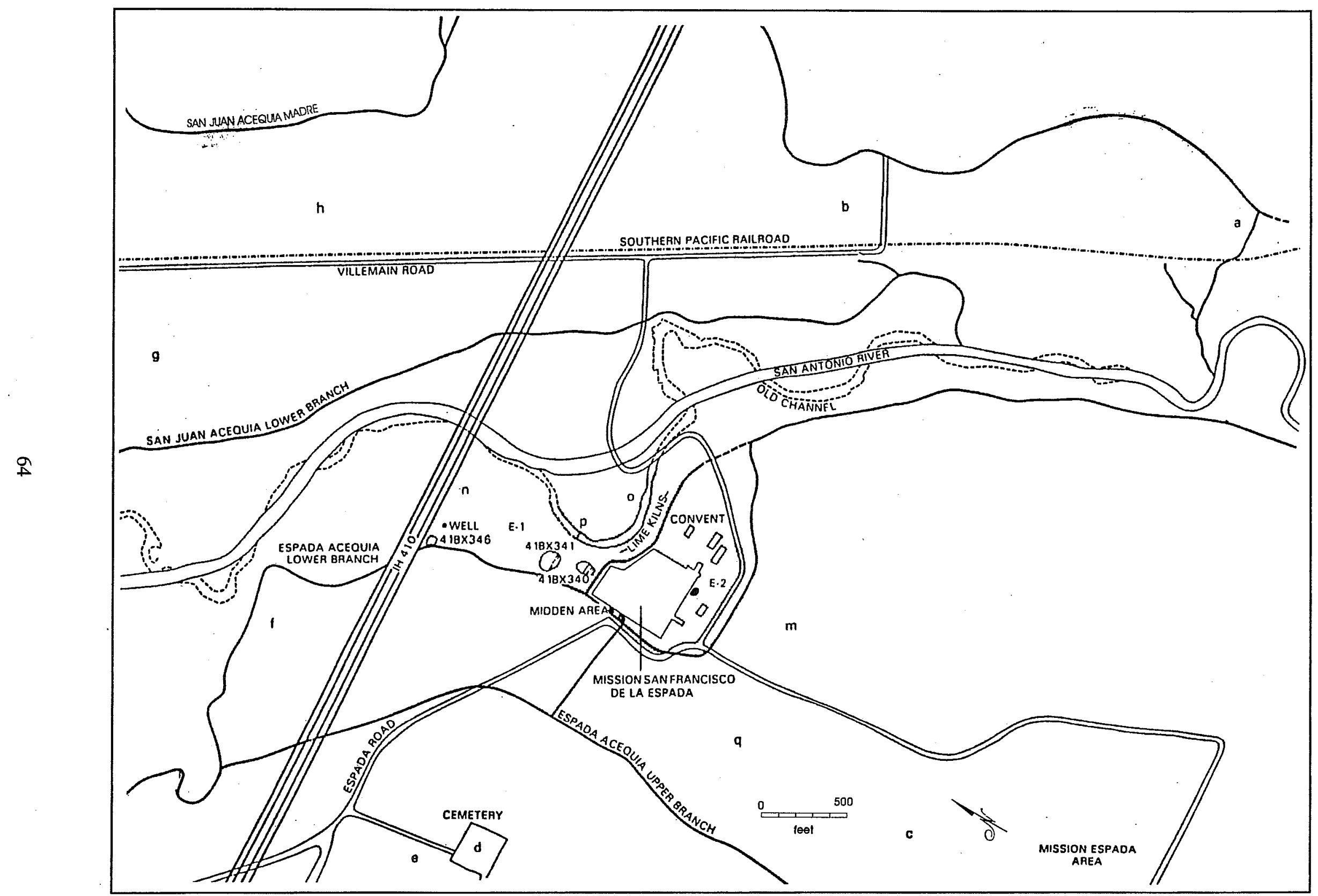

Figure 20. Mission Espada area. 
the south on this same line. It could be a natural drainage or the trace of an irrigation canal.

Area d appeared to consist of definite cultural materials west of Espada acequia; south of Loop 410. It appeared to be a small cemetery (Figure 20).

This proved to be a private cemetery used by the local community. A descendent of the original owners administers it at present. The earliest grave marker is dated 1886 (see Fox 1981).

Area e appeared to consist of soil and vegetation alignments in the form of true alignments, not cultivated, possibly associated with Area d (Figure 20).

This is previously cultivated land with a small shed in the center of the area. It appears to be divided into small, individual fields. We could find no local explanation, but would guess it was developed after 1900. The only possible connection with Area d is land ownership.

Area $\mathbf{f}$ is probably the extension of an acequia pond drainage ditch. It appears to rise over a small hill and into the river north of Loop 410, between Espada Road and the river (Figure 20).

This was found to be a branch of the Espada acequia, which was cut off by river channel construction in 1970 .

Area g appeared to be a linear extension of Area j, a quarter of a mile north of Interstate Highway 410 , ca. 1/8 mile west of the railroad (Figure 20).

This area has been in continuous irrigated cultivation since mission times. The anomaly could be an old acequia lateral or it could be a natural drainage.

Area $\mathbf{h}$ appeared to be a linear extension of Area I (Figure 21).

This may or may not be so. There is nothing visible on the ground (see above).

Area i (slight depression and soil mark, appears to be extending from present gate at mission, may connect with Areas $h$ and $b$. Initial reaction is these anomalies may be the remains of a road or trail (Figure 21).

This is probably an old trace of an acequia lateral (see above). If it once was a road, all evidence has been eliminated on the surface by later cultivation.

Area $\mathbf{j}$ appeared to be an area of acequia and railroad, a linear soil mark due south of Mission San Juan. Informant suggests it is a refilled feeder ditch (Figure 21).

This suggestion is probably correct. It lines up well with one farther north. There is no evidence on the surface.

Area $\mathbf{k}$ is a large mound measuring $500 \times 300 \mathrm{ft}$ surrounded by a depression, an old meander scar around a gravel pile; height is ca. $3 \mathrm{ft}$ across river from Area $\mathrm{j}$. This was checked by Jim Bradford during an earlier survey (Figure 21).

This area on the Olivas property contains a prehistoric site (41 BX 254) and a historic site(41 BX 255), recorded by the Mission Parkway survey in 1974 (Scurlock et al. 1976). Bradford and Fox visited the area briefly in 1980 . Fox, Gonzales, and Cox surveyed the area intensively in November 1981 and made a surface collection. The original estimate of site sizes and locations has been revised as a result of this study.

Site 41 BX 254 extended from the edge of the right-of-way to the far side of a gravel mound ca. 400 feet to the west and from the north boundary of the Olivas property across a cultivated field on the south side of the south Olivas fence line. Very few prehistoric artifacts were found in the areas to the east and south, but 13 chert flakes and fragments were found scattered on the surface north of the house site concentration. Fox and Bradford collected a number of chert flakes and fragments south of the Olivas fence in 1980.

Site 41 BX 255 is an area of nineteenth- and early twentieth-century occupational debris concentrated on the north end of the gravel mound. Judging particularly from the ceramics, the site was occupied from pre-Civil War to just after 1900. This agrees with the information provided in the 


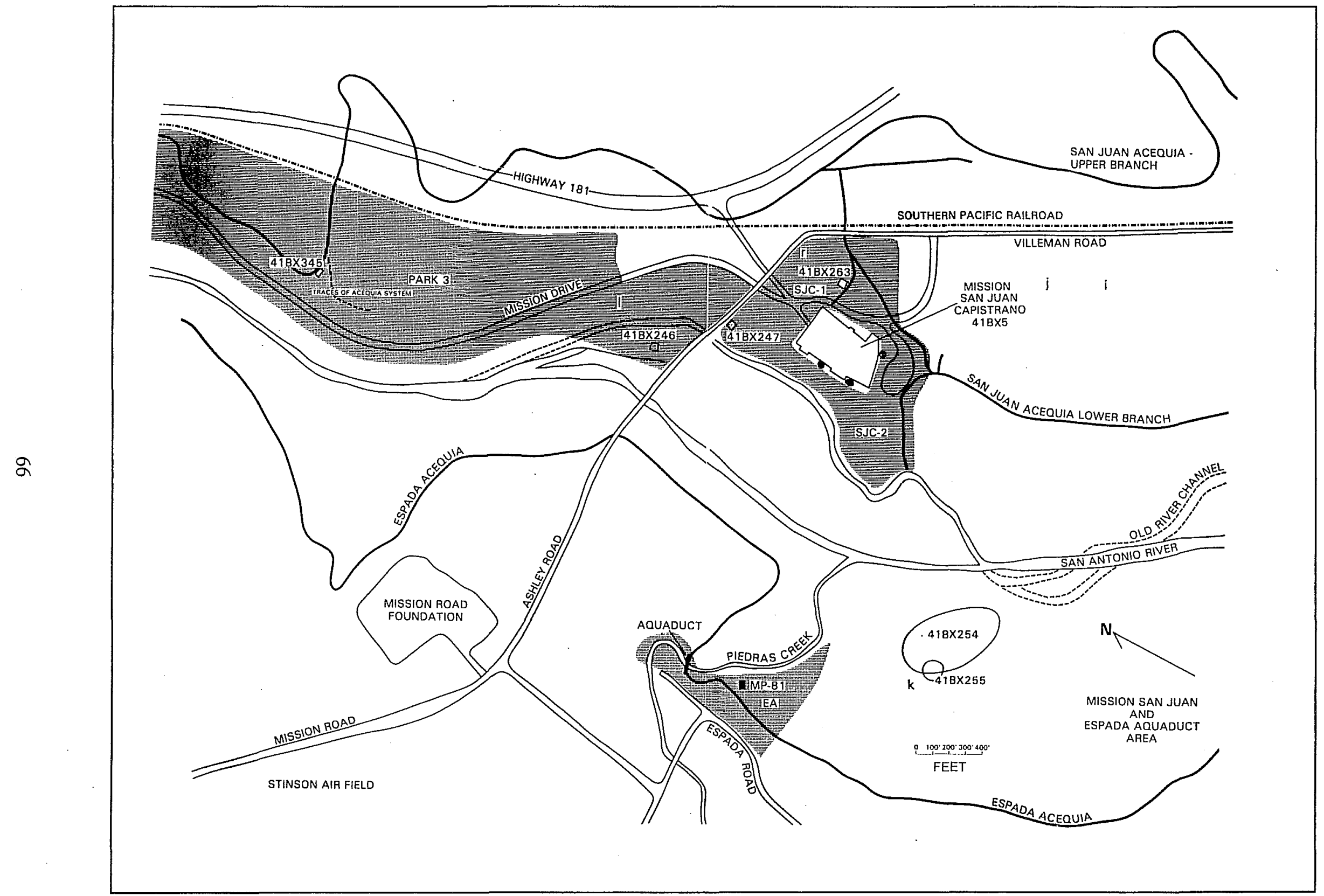

Figure 21. Mission San Juan and Espada Aqueduct area. 
Mission Parkway survey that the house was occupied from the late nineteenth century until 1901 (Scurlock et al. 1976:100). For a list of artifacts collected, see Table 1.

Area 1 appeared to be a depression north of Ashley Road aligned with currently flowing stream, probably a result of channelization (Figure 21).This was the old river channel before 1970 .

Table 1: Artifacts Collected from 41BX255

\begin{tabular}{|c|c|}
\hline Quan. & Description \\
\hline 12 & chert flakes and fragments \\
\hline 13 & clear bottle glass \\
\hline 1 & chert core \\
\hline 1 & green bottle glass \\
\hline 1 & sherd Goliad ware \\
\hline 2 & cobalt bottle glass \\
\hline 1 & sherd lead-glazed redware \\
\hline \multirow[t]{2}{*}{6} & fragments tin cans and \\
\hline & miscellaneous metal scrap \\
\hline 1 & sandstone disc \\
\hline 57 & sherds whitewares \\
\hline 1 & blue bead \\
\hline 1 & banded slip pearlware \\
\hline 2 & cut sponge pearlware \\
\hline 1 & blue transfer pearlware \\
\hline 4 & decal earthenware \\
\hline 1 & metal button \\
\hline 1 & shell button \\
\hline 1 & pocket knife \\
\hline 2 & fragments harmonica reed \\
\hline 9 & porcelain \\
\hline 1 & iron tool fragment \\
\hline 2 & yellowware \\
\hline 1 & chain link \\
\hline 9 & Bristol-glazed stoneware \\
\hline 1 & harness buckle \\
\hline 4 & slip-glazed stoneware \\
\hline 1 & iron hame \\
\hline 1 & salt-glazed stoneware \\
\hline 7 & fragments window glass \\
\hline 9 & lavender bottle glass \\
\hline 1 & cut nail \\
\hline 3 & olive bottle glass \\
\hline 2 & wire nails \\
\hline 5 & brown bottle glass \\
\hline 2 & fragments red brick \\
\hline 1 & aqua bottle glass \\
\hline
\end{tabular}

Area $\mathbf{m}$ is a dark rectilinear soil pattern beyond the modern water pond tank, south of Espada. These are possible irrigation features covered by modern field development (Figure 20).

Nothing could be found on the ground to explain this anomaly.

Area $\mathbf{n}$ is a light rectangular soil pattern, north of Espada (Figure 20).

There appear to be remains of some sort of concrete substructure beneath the surface here. Artifacts in the area are contemporary building materials. It is suggested that this may have had something to do with the construction of the interstate highway.

Areas 0 and $p$ are anomalies in the bend of the old river bed northeast of Espada (Figure 20).

This area has been badly disturbed by the construction of the new river channel. The anomalies appear to be gravel mounds. No historic or prehistoric artifacts were found.

Area $\mathbf{q}$ consisted of soil marks in the cultivated fields southwest of Espada (Figure 20).

No evidence could be found on the surface. These fields have been cultivated and irrigated by so many generations of local inhabitants that it is virtually impossible to determine anything about their appearance in mission times.

Area $\mathbf{r}$ consisted of soil marks in field northeast of Mission San Juan; Figure 21). There is no surface evidence to account for anomalies in this area, and no artifacts are present on the surface.

Area s was a vegetational anomaly outside the east wall of Mission San José (Figure 22).

Numerous small twentieth-century houses in this area have recently been removed. We believe the anomaly is a result of the remaining shrubbery and subsurface disturbance related to one of those houses. 


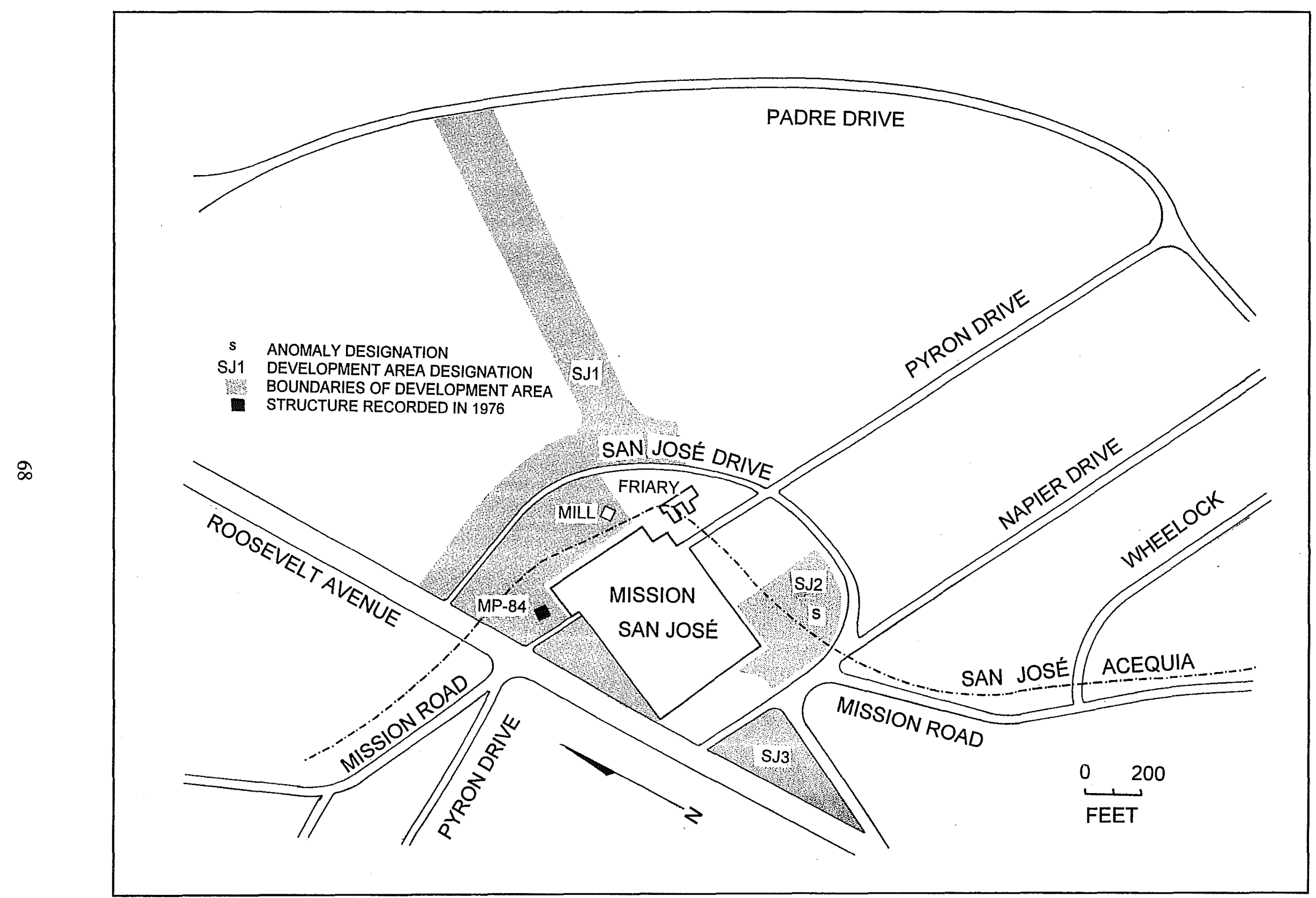

Figure 22. Mission San José area. 
Area $\mathbf{t}$ consisted of vegetational patterns and depression in the field west of Mission Concepción (Figure 23).

The depression is the unfilled portion of the quarry used for mission construction. The vegetational pattern appears to include several large pecan trees which are located near the line of the original west wall of the mission. This area was bulldozed ca. 1960 (see Part II of this report), which could account for confused anomalies on the surface.

Area $\mathbf{u}$ consisted of a mound and lineations in field southwest of Mission Concepción (Figure 23).

The linear mark that runs northwest-southeast is the original location of Mission Road. The line that runs northeast-southwest is the remains of an asphalt driveway between the orphanage and a religious shrine which has been constructed in the quarry. The mound in the area contains chunks of stone that appear to have come from the quarry. It is probably a product of the quarrying operation. No historic artifacts are present on the surface.

Area $\mathbf{v}$ consisted of patterns in the open space north of Mission Concepción (Figure 23).

This area was the location of various playing fields for the seminary students. The marks are remnants of structures such as walls and backstops for those activities.

\section{The Development Areas}

\section{Concepción (Figure 23)}

C-1 (seminary grounds (see also Area v). This area between Mitchell Street and the north wall of the present park is divided approximately in half by the tree-lined driveway into the old seminary. The area to the north was used as a playing field for various sports by the seminary students. The area to the south contained a formally landscaped garden and lawn area surrounded by trees. In mission times, the north wall of the mission, which had a row of Indian quarters built against it, stood beneath the present driveway. The field to the north of this line was outside the mission walls; the gardens to the south were inside (see Figure 1). As explained above, anomalies in the field (Area v) are probably related to the playing fields. If there was an entrance to the mission on this wall at one time, we might expect to find mission period trash pits somewhere in this area. Since the area to the south of the drive was within the mission, it should contain structural and artifactual remains wherever these have not been removed by landscaping.

C-2 (area north of Theo Avenue) This area is completely built over with twentieth-century homes, commercial establishments, driveways, and cultivated yards. Ninety-nine percent of this area lies outside the west wall of the mission, and the mission road ran through one corner of it. With the possible exception of the alignment of the commercial building on the corner of Mission Road and Theo Avenue, no suggestion of the original mission outline remains in this area, and no mission-related artifacts are visible on the surface.

C-3 (area south of Theo Avenue; see also Areas t and $u)$ This area contains a number of mission-related remains (Figure 2). The southwest corner of the compound is in the northeast quadrant. The mission acequia crossed the northern section. Mission Road once ran in a westerly curve north and south across the area. The quarry from which much of the stone was taken to build the mission is located just north of the center of this area. According to local informants, this entire area was leveled by a bulldozer ca. 1960 .

C-4 (area south of mission) This area is paved with asphalt and used for visitor parking. We estimate that the convent building at one time extended into this area at least as far south as the line indicated in Figure 23 and that a branch of the acequia crossed here somewhere. It is also more than possible that an earlier building sequence extendedeven farther south into this area.

\section{San José (Figure 22)}

SJ-1 (area north and west of mission). The narrow corridor between Padre Drive and San José Drive and the area along the north edge of San José Drive are heavily wooded and have a thick ground cover of dead leaves. Trash dumping has gone on in this area for many years, and mounds containing brick fragments, concrete chunks, and gravelly soil along 


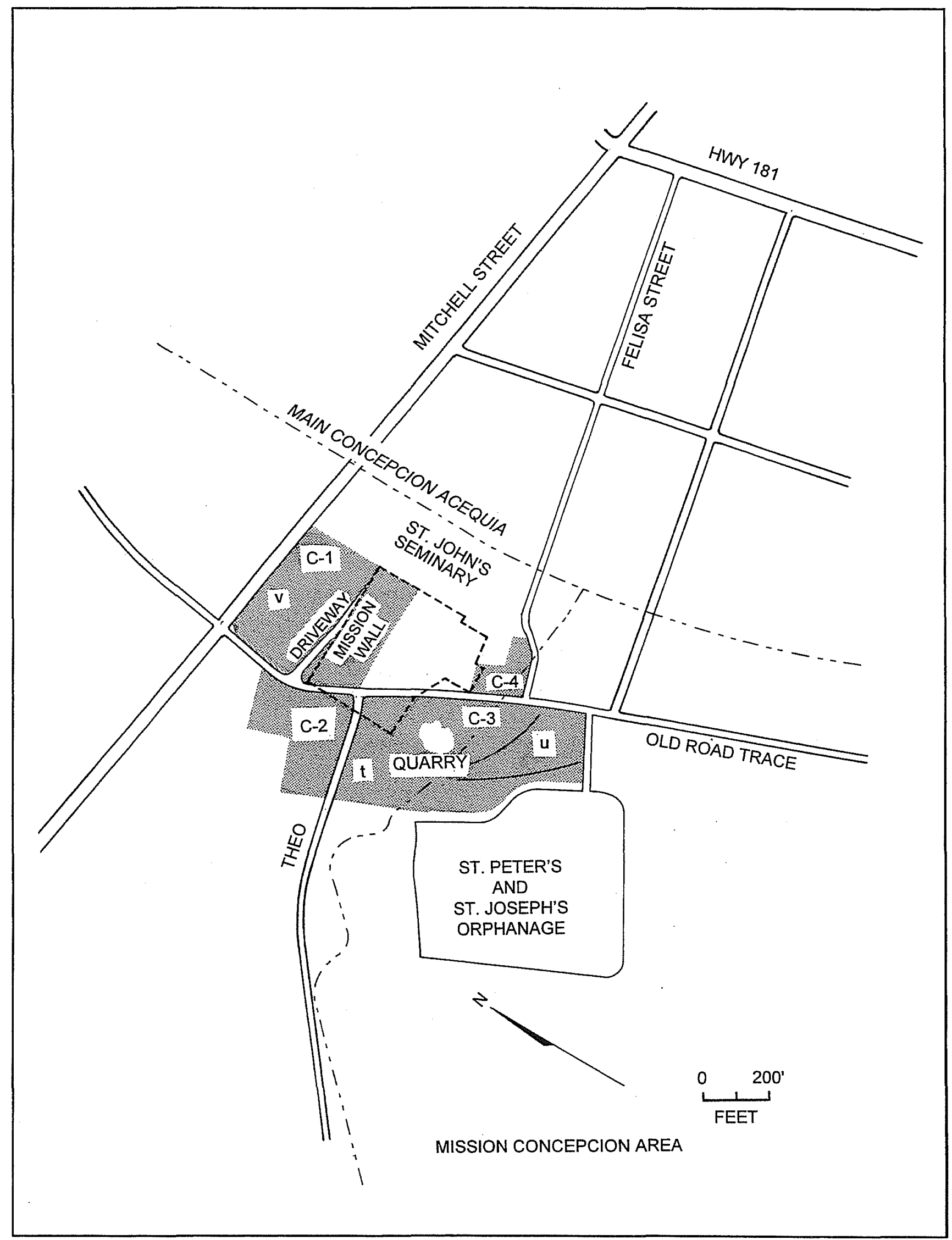

Figure 23. Mission Concepción area. 
with twentieth-century artifacts are frequent. There is no evidence of in situ structural remains, and no artifacts were seen on the surface which could date earlier than the $1930 \mathrm{~s}$. One interesting anomaly is a ditch that runs northeast from Padre Drive, then turns northwest and gradually disappears. It was not possible to determine the age of this feature, but it could be a remnant of the original acequia system. The area between San José Drive and the north wall of the mission contains an outdoor theater constructed in an old gravel quarry and other structures connected with the theater and the park. The mission acequia ran through this area and crossed Roosevelt Avenue at about the point indicated; the acequia route was revealed during construction of the street many years ago (Ethel Harris, first Park Superintendent; personal communication). The mission grist mill has been restored to its original site just north of the acequia. Until recently, several post-1900 structures stood in the area between the acequia and Pyron Drive where it runs up to the mission gate. At the time they were built, this road ran completely through the mission. Site MP-84, recorded by the Mission Parkway survey ( Scurlock et al. 1976:163), was the Reyes House, whose owner and occupant was a descendant of early settlers in the area. This house has been removed, but scattered remains of its foundation and its outbuildings are still visible.

The triangle south of Pyron Drive between Roosevelt Avenue and the mission was once the site of several small homes. A sprinkler system trench placed in this area revealed a number of interesting details in April 1968 (Schuetz 1970:8-14). Numerous nineteenth-century artifacts were concentrated for the most part near the center and toward the south end of the trench, which ran parallel to the wall. Spanish artifacts tended to increase toward the north end of the trench and were intense at the gate area, where it appears there is a large midden of mission materials.

SJ-2 (area around the southeast corner; see also Area s). A number of small residences once stood in this area. They have recently been removed, leaving scattered concrete and stone fragments and alignments of shrubs and trees to show where they once stood. The mission acequia ran through here, and the point where it crossed Napier Drive was recorded by State Department of Highways and
Public Transportation archaeologists during reconstruction of the road in February 1981 (Jerry Henderson, personal communication).

SJ-3 (triangle south of the mission). This area was carefully examined twice, and no evidence of any activity earlier than the 1930 s was found. Trash from commercial establishments in the surrounding area and evidence of an asphalt-paved driveway are the only remains on the surface.

\section{San Juan Capistrano (Figure 21)}

SJC-1 (area north and east of mission; see also Area $\mathrm{k}$ ). This area contained a cluster of small homes, most of which were removed between 1967 and 1970. Site $41 \mathrm{BX} 247$ is the location of the Bazan house and store (Scurlock et al. 1976:91), which operated in the early 1900s. This is in the center of what was once the Berg's Mill community (Scurlock et al. 1976:227-243), which formed in the last half of the nineteenth century around a series of mills on the river. Only a few extensively renovated houses remain in this portion of the survey area, and it is not known if any pre- 1900 structures are contained within them. No early nineteenth-century artifacts were observed on the surface. Extensive archival and archeological research would be required to determine what was present in the post-mission period.

The northeast quadrant of SJC-I is primarily occupied by a small farm owned and rented out in 1974 by Miss Lillian Daura (Scurlock et al. 1976:154-155, Figure 31,a). The house (41 BX 263) appears to have been built in the 1880 s or 1890s. The present occupants keep a large, unfriendly billy goat who limited the present survey to an over-the-fence study of the area immediately behind the house on the north and east. A lateral of the main San Juan acequia runs through this area, and this study has for the first time located a branch of the old system which may once have run through the compound. This location is confirmed on the 1963 map of the acequia by Williams-Stackhouse and Associates that shows this channel running up to the northeast corner of the compound and stopping. Except for the acequia channel, no traces of mission period structures or artifacts were found in SJC-I. 
The report of the 1974 Mission Parkway survey (Scurlock et al. 1976:139) also mentions a midden deposit outside the north wall of the mission that was revealed by a drainage ditch cut through it. The exact location of the midden was not indicated, but apparently it was west of the gate (Ivey, personal communication).

SJC-2 (area south and west of the mission). Aside from the acequia channel, no structural remains were found in this area. In the southwest section the land slopes gradually from the mission to the river. This section is wooded and natural in appearance. The steeper bank to the north where the river channel swings closer to the walls is marred by generations of dumping of building debris and trash. This is particularly exasperating since it is likely that the mission once had lime kilns in the bank. The author has first-hand knowledge of extensive mission middens immediately outside the gate in the west wall just south of the church and outside the gate in the south wall. Schuetz (1968:Figures 1 and 19) confirmed the presence of numerous buried foundations adjacent to the west wall and an extensive gate midden immediately to the north of these. In the 1880 s, a road ran down to a ford on the river somewhere in this area (Scurlock 1976:Map 7).

The entire area between the mission and the river should, therefore, be considered a sensitive one. The old route of the acequia lateral, which once returned to the river south of the mission, can still be traced in the ground. It seems likely that this area may once have all been open, cultivated fields and gardens of the mission.

\section{Espada Aqueduct (Figure 21)}

EA (area between Espada Road and Piedras Creek). The only Spanish remains in this area are the Espada acequia and its aqueduct over Piedras Creek. There are a number of small houses in the area in various stages of decay and remodeling. Of these, the only one (MP-81) recorded by the Mission Parkway survey (Scurlock 1976:162, Figure 33,a) was of post-1900 vintage and had been abandoned for many years. No Spanish or
pre-Civil War artifacts or structures were found during the survey in this area.

Espada (Figure 20)

E-1 (area north of the mission; see also Areas n, o, and p). Three new archeological sites were recorded in this area during the survey. Site $41 \mathrm{BX}$ 340 is an oval-shaped scatter of Spanish and Anglo-American artifacts in a cultivated field, ca. $100 \times 50 \mathrm{ft}$, just north of the old acequia outside the north wall. The first survey collected 15 eighteenth- and nineteenth-century sherds and a number of related artifacts (Table 2). To determine the possible implications for future development in this area, a series of three 12 -in cube shovel tests were excavated across the site on a north-south line ca. $30 \mathrm{ft}$ west of the top of the river bank. Two tiny Spanish-period sherds, one chert flake, and one

Table 2: Artifacts Collected from 41BX340

\begin{tabular}{|l|l|}
\hline Quan. & Description \\
\hline \multicolumn{2}{|l|}{ Surface: } \\
\hline \multicolumn{2}{|l|}{ None } \\
\hline 1 & projectile point fragment \\
\hline 1 & sherd Goliad ware \\
\hline 36 & chert flakes and fragments \\
\hline 1 & chert flake \\
\hline 1 & quartzite flake \\
\hline 1 & fragment clear glass \\
\hline 1 & fragment sandstone metate \\
\hline 2 & fragments burned animal bone \\
\hline 1 & sherd polychrome maiolica \\
\hline Test \#2 & \\
\hline 1 & sherd undecorated pearlware \\
\hline 1 & sherd hand-painted pearlware \\
\hline 1 & fragment ochre \\
\hline 6 & sherds ironstone \\
\hline 1 & chert flake \\
\hline 1 & sherd hotelware \\
\hline 2 & fragments tin can \\
\hline 1 & contemporary marble \\
\hline Test \#3 & \\
\hline 1 & 1977 U.S. cent \\
\hline 10 & fragments contemporary \\
\hline \multicolumn{2}{|l|}{} \\
\hline 1 & lead glazed redware \\
\hline & sherd building tile \\
\hline
\end{tabular}


glass fragment were recovered by screening the soil from these tests. We are now convinced that the site consists of a surface scatter of eighteenth- and nineteenth-century artifacts, possibly derived from the annual cleaning of the acequia and then gradually spread across the field by later erosion and cultivation.

Site 41 BX 341 is a scatter of post-1900 artifacts (Table 3) over an area approximately 100 feet in diameter. No traces of structure are visible, and it may be merely an overflow from the dumping which has disfigured the east bank of the acequia.

Site 41 BX 346 contains the ruins of a small post-1900 house on top of a rise overlooking the river valley. A stone-lined well at the foot of the hill is probably related to the structure. There is no apparent relationship between this house site and Area n nearby.

Just north of the wall of the mission is the channel of an early acequia. This appears to have been abandoned in the late eighteenth or early nineteenth century. The encroaching erosion of the river bank has undercut and collapsed it at one point. A number of lime kilns have also been dug into the bank in this area (A. Fox 1970; Killen and Scurlock ca. 1978).

Table 3: Artifacts Collected from 41BX341

\begin{tabular}{|l|l|}
\hline Quan. & Description \\
\hline Surface: \\
\hline 3 & chert fragments \\
\hline 3 & fragments plastic \\
\hline 22 & sherds ironstone \\
\hline 2 & fragments tin can \\
\hline 3 & sherds hotelware \\
\hline 5 & fragments oyster shell \\
\hline 14 & sherds earthenware, painted overglaze \\
\hline 1 & fragment burned bone \\
\hline 1 & sherd painted, unglazed Mexican ware \\
\hline 17 & fragments yellow/tan brick \\
\hline 1 & sherd porcelain \\
\hline 34 & fragments clear glass containers \\
\hline 2 & fragments pink brick \\
\hline 3 & fragments green milk glass \\
\hline 1 & fragment concrete \\
\hline
\end{tabular}

E-2 (area east, south, and west of the mission). This area contains a number of twentieth-century buildings: a large stone structure on the south side currently used as a meeting hall; buildings constructed for a local school off the southeast corner; and a convent building built ca. 1957 for the Sisters of the Incarnate Word on the northeast (Fox 1981:7). The convent area was thoroughly surveyed in 1980 by Fox and Markey, and the area between there and the corner bastion was crossed by utility trenches monitored by the author in 1979 (Fox 1979). No mission-related artifacts or structures were found on this side of the mission. Stone foundations located adjacent to the northeast corner were twentieth century in origin (Fox 1981:7).

On the south and west sides of the mission walls are some areas of archeological concern. Outside the south gate, a midden area periodically yields Spanish and Indian artifacts. There is a similar midden on each side of the gate at the west wall. The reconstructed outline of a granary identified by Smith protrudes from the south wall, and a number of questions remain about the outlines and construction of this building, and whether other structural remains may be found beneath the surface in the area between it and the road. Also in that area were number of nineteenth-century buildings which might merit further investigation (Ricardo Ramirez, personal communication).

\section{Park Areas}

Park 1 (Espada Dam area; Figure 24). An archeological survey and testing were done at the north end of this park by CAR in 1978 (Valdez 1978) at the request of the San Antonio Department of Parks and Recreation. This was in preparation for construction of restroom facilities. No archeological sites were found. The remainder of the park was examined, and no structural or artifactual remains were visible. The area is probably too low and too vulnerable to flooding to encourage human habitation.

Park 2 (area across the river from Espada Dam; Figure 24). This area contained spoil heaps from 


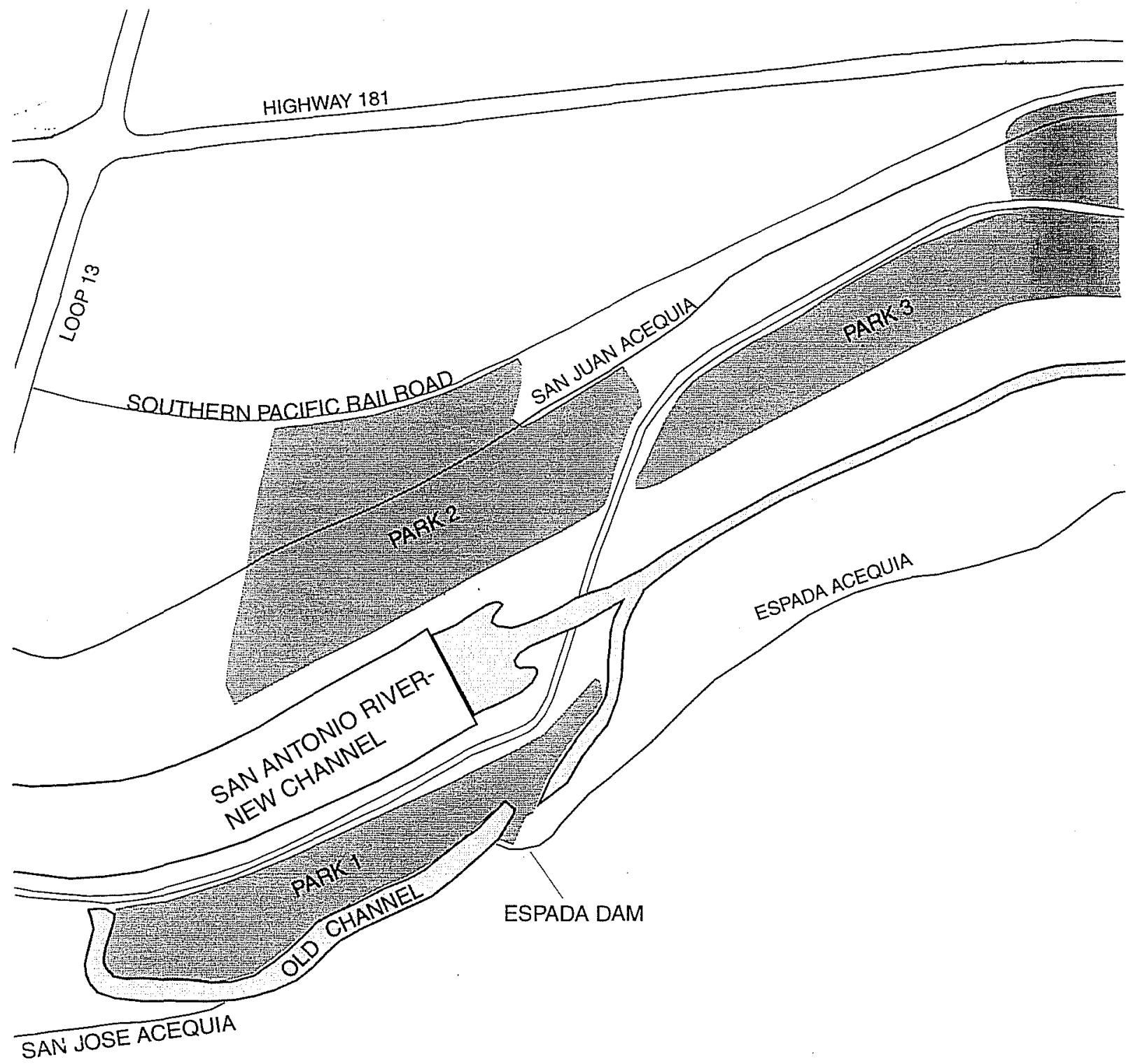

MISSION BURIAL PARK
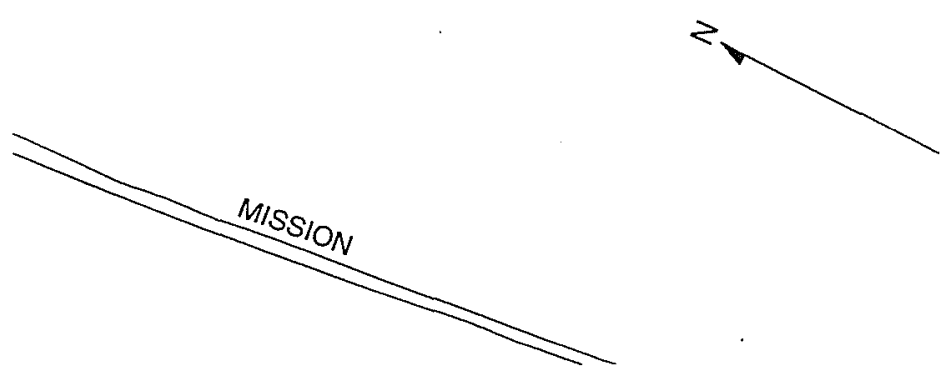

$\underbrace{0100}_{\text {FEET }} 200$

Figure 24. Espada Dam area. 
river dredging and dumps of material from surrounding commercial development. The San Juan acequia crosses the eastern portion of the area. This section was dredged during renovation in 1967. The area is thickly wooded and has a heavy ground cover of leaves and weeds which hampered the surface survey. However, it is not believed any historic or prehistoric sites are present.

Park 3 (area between San Juan and Espada Dam, east of the park road; Figure 24). Conditions in this area are similar to those in Park 2. However, an archeological site, $41 \mathrm{BX} 345$, was recorded in the center of the park. This is a small 1920s concrete house foundation with related trash and irrigation channels in a nearby wooded area which undoubtedly was open fields at that time. The dates 1922 and 1927 are inscribed in the cement of the control gates on the ditches. No other sites were recorded in this park area. However, it should be mentioned that the ruin of an old mill, site $41 \mathrm{BX}$ 246, stands north of Ashley Road between the old and the new river channels. The history of proprietorship is not yet clear (Scurlock et al. 1976:86-90).

\section{Summary and Conclusions}

The survey examined 22 anomalies, five development areas, and three park areas. Seven previously recorded archeological sites and historic buildings were relocated and examined: four new sites were recorded. A number of areas known by the author to contain mission middens have also been recorded for future reference, and wherever possible postulated acequia routes have been confirmed. This report pulls together incidental information gained by the survey and accumulated by the author during 15 years of archeological work in and around the missions. This is submitted for use by the National Park Service in planning future development around the missions, in the hope that archaeologically sensitive areas will be protected. 


\section{References Cited}

Clark, J.

1978 Mission San José y San Miguel de Aguayo: Archeological Investigations, December 1974. Report No. 29 Texas Historical Commission, Office of the State Archeologist, Austin.

Clark, J. and E. Prewitt

1979 Archeological Test Excavations in an Area to be Affected by a Proposed Trench Drain West of the Granary: Mission San José State Historic Site (41 BX 3), Bexar County, Texas. Report of Investigations, No. 3. Prewitt and Associates, Inc., Austin.

Fox, A. A.

1970 "Preliminary Survey of Pits at Mission Espada, December 26, 1970." Copy on file; Center for Archaeological Research, The University of Texas at San Antonio.

1979 "Letter report to Curtis Tunnell, State Archeologist, July 2, 1979." Copy on file; Center for Archaeological Research, The University of Texas at San Antonio.

1981 Test Excavations at Mission San Francisco de la Espada, May 1981. Archaeological Survey Report, No. 108. Center for Archaeological Research, The University of Texas at San Antonio.

Fox, A. A. and T. R. Hester

1976 Archaeological Test Excavations at Mission San Francisco de la Espada. Archaeological Survey Report, No. 22. Center for Archaeological Research, The University of Texas at San Antonio.

Fox, D. E.

1970 Archeological Salvage at Mission San José, December 1969, April and August 1970. Texas Historical Survey Committee, Austin.

Killen, K. L., and D. Scurlock

ca.1978 "A Report on Preliminary Test Excavations at Mission Espada Kilns, San Antonio, Texas." Preliminary Draft. Manuscript on file; Texas Historical Commission, Austin.

Medlin, T. W., and W. Roberson

1976 San José Mission State Historic Site Archeological Testing 1974 and 1976, Antiquities Permit No. 65. Letter report. Copy on file; Center for Archaeological Research, The University of Texas at San Antonio.

Schuetz, M. K.

1968 The History and Archeology of Mission San Juan Capistrano, San Antonio, Texas (Vol. 1). Historical Documentation and Description of the Structures. Archeological Program Report, No. 10. State Building Commission, Austin.

1969 The History and Archeology of Mission San Juan Capistrano, San Antonio, Texas (Vol. 2). Description of the Artifacts and Ethno-History of the Coahuiltecan Indians Archeological Program Report, No. 11. State Building Commission, Austin.

1970 Excavation of a Section of the Acequia Madre in Bexar County, Texas, and Archeological Investigations at Mission San José in April, 1968. Archeological Program Report, No. 19. Texas Historical Survey Committee, Austin.

1974 The Dating of the Chapel at Mission San Juan Capistrano, San Antonio, Texas. Special Report, No. 12. Office of the State Archeologist, Texas Historical Commission, Austin. 
1980 History and Archeology of Mission San Juan Capistrano, San Antonio, Texas (Vol. 4). Excavation of the Convento. Manuscript on file; Office of the State Archeologist, Texas Historical Commission, Austin.

Scurlock, D.

1976 Archeological and Architectural Tests at Mission San Juan Capistrano Church, March and April, 1975. Special Report, No. 21. Office of the State Archeologist, Texas Historical Commission, Austin.

Scurlock, D., A. Benavides, Jr., D. Isham, and J. Clark

1976 An Archeological and Historical Survey of the Proposed Mission Parkway, San Antonio, Texas. Archeological Survey Report, No. 17. Office of the State Archeologist, Texas Historical Commission, Austin.

Scurlock, D. and D. E. Fox

1977 An Archeological Investigation of Mission Concepción, San Antonio, Texas. Report, No. 28. Office of the State Archeologist, Austin.

Valdez, F., Jr.

1978 "Archaeological Assessment of Espada Park Restroom Facility Area, San Antonio, Texas." Manuscript on file; Center for Archaeological Research, The University of Texas at San Antonio. 


\section{Appendix I \\ Excerpts from the Deed Records}

The following are excerpts from the deed records which give the most direct evidence for the outline of the pueblo of Mission Concepción and the location of the granary (Figure 2).

For these deeds, measurements in varas are converted to feet [within brackets], using a vara of 2.777 feet, the accepted length among Texas surveyors after 1836. Source information uses the abbreviations BCDR for Bexar County Deed Records, BCA for Bexar County Archives, MR for Mission Record, DSB for District Surveyor's Book, and CSB for City Surveyor's Book. All are located in the Office of the County Clerk, Bexar County Courthouse, San Antonio, Texas.

Spellings of words and names in the original deeds have been kept in these excerpts.

\section{Ramón Músquiz to Rt. Rv. John M. Odin}

"Know all men by these presents, that I, Ramon Musquiz, of Montclova, Republic of Mexico, for and in consideration of the sum of one dollar to me in hand paid by the Rt. Rev. John M. Odin of the County of Galveston and State of Texas . . . deliver unto the said John M. Odin . . . the following described property consisting of land and buildings there on situated, being a part of the old Mission of La Concepción, about 21/2 miles, below and South of the City of San Antonio, Bexar County, sold to me by the Mexican authorities, on the 14th of August, A.D. 1824, and described as follows: a stone building, with an earthen roof, consisting of a Porch fronting to the west on the Plaza of the Mission, thirty nine (39) varas [108.3 ft], a saloon (salon) with an adjoining room and gallery, of the same length, and a Porch on the east of eighteen (18) varas [50 ft] with two arches closed, to form a Kitchen, with a depth to the South of ninety seven (97) varas [209.5 ft] belonging to said House and forming a corner towards the east, there is an excess of seven varas [19.4 ft] on the front and running south seventeen [ $47.2 \mathrm{ft}$ ], to which is added 8 varas [ $22.2 \mathrm{ft}]$ more to the same front, with depth to the boundary of the 97 varas. Bounded north by the Church, East by the Sacristy and Labor granted to R. Musquiz, south by the S. José Road, and west by Plaza . . ." (BCDR Vol. Sl:480, Oct. 23, 1860).

\section{Ramón Músquiz to E. C. Dewey}

"A tract of land situated in the Labor of the Mission Concepción . . . containing 65 acres with its proportion of water beginning at the northeast corner of the old wall of the Mission Concepción, Thence with the upper line of said wall N $841^{\circ}{ }^{\circ} \mathrm{W} 145$ varas [402.7 ft] to the old Mission Road, thence with said road N $10^{\circ}$ E 100 varas [277.7 ft] to the northwest corner of this tract . . . [metes and bounds of remainder of tract given] . . . Thence $\mathrm{N} 8^{\circ} \mathrm{W} 155$ varas [ $430.0 \mathrm{ft}$ ] Thence $\mathrm{N} 85^{\circ} \mathrm{W} 781 / 2$ varas [218 ft] to the wall of Concepción thence with said wall $\mathrm{N} 3^{\circ} \mathrm{E} 112^{1 / 2}$ varas [312.5 ft] to beginning . ." (BCDR Vol. H2:250, Oct. 2, 1857).

\section{3a. Petition of Manuel Yturri y Castillo for land south of Mission Concepción}

At the end of this petition, Yturri includes: "Otro si suplico á V.S. se digne concederme la pieza q. ${ }^{\mathrm{e}}$ servia de troxe a dh. ${ }^{a}$ Mision su clase de arrendamiento a venta, gracia que recivire. . ." (BCDR Vol. A2:77, Nov. 5, 1823; BCA-MR 33).

\section{3b. Manuel Yturri y Castillo and Josefa Rodríguez to Asa Mitchell}

"Know all men by these presents, that we, Manuel Yturi Castillo and Josefa Rodriguez his wife . . convey unto Asa Mitchell . . . a certain lot or parcel of land situated at and being part of what is known and the mission lands of the church of the Concepción, on the east side of the San Antonio river, the said lot has three rooms, built of stone, and connected together in a row, which adjoins the said church at its south-east corner ..." (BCDR Vol. A2:74, Aug. 1838). 
3c. Manuel Yturri y Castillo and Josefa Rodríguez to Asa Mitchell

"Know all men by these presents, that we, Manuel Yturri Castillo and Josefa Rodriguez his wife . . convey unto Asa. Mitchell . . . a certain tract or parcel of land situated on the eastern bank of the river San Antonio below and near to the mission Concepción, bounded on the east side by the outside road ("camino de afuera") of the mission of San Juan; on the north by the road which runs out from the church of the Concepción ("sale de Concepción p. a afuera"); on the west by the San José road to where it crosses the river San Antonio, and on the south side by the said river as far down as to the ford called and known as the Paso de las Custeras; which tract . . . consists of four large lots called and known as suertes, three of which suertes were lawfully granted and rightfully put into the possession of the abovenamed Yturri Castillo, by José Antonio Saucedo, political chief of the department, \&c. on the 6th day of December, A. D. 1823, and the remaining or fourth suerte contained within the above boundaries was lawfully granted and rightfully put into the possession of Baltazar Calbo ... ." ( BCDR Vol. A2: 73, 17 Aug. 1838).

\section{Survey of land sold to Asa Mitchell by Manuel Yturri y Castillo}

"Field notes of a survey of $3491 / 2$ acres of land made for Asa Mitchell Said Survey is situated on the East bank of the San Antonio River about three miles below the City of San Antonio and known as Yturies Survey bounded on the north by the Mission lands of Conception and a Survey in the name of Thomas Thatcher on the East by said Survey on the South by the river and on the west by Mission Lands . . ." [metes and bounds of remainder of tract given] ". . N 11/1/2 ${ }^{\circ} \mathrm{W} 400$ varas [111.1 $\mathrm{ft}$ ] to the SW corner of an old house formerly occupied by Yturie Thence $\mathrm{N} 5^{\circ} \mathrm{E}$ along the West wall of Said house 32 varas [88.9 ft] to where Said house joins the conception Mission Thence at right angles with the mission wall S $85^{\circ} \mathrm{E} 95$ varas [263.9 $\mathrm{ft}$ ] to an old Ditch . . ." (BCA-DSB Vol. F-1:32-33, March 16, 1849; BCDR Vol. P1:619-620, March 16, 1849).

\section{De La Garza and Delmour to Bishop Odin}

"Where as Refugio de la Garza . . . did in the year 1838 sell the lands as hereinafter described to the Said Delmour, and not having made the coresponding deed of conveyance to the Said Delmour, now comes the said Refugio de la Garza with the consent of William B. Jaques administrator of the Estate of William P. Delmour dec'd. and makes this deed of conveyance direct to the Rev.d John M. Odin . . . all that tract or parcel of land situated in the County of Bexar, on the East bank of the San Antonio river, and near the Mission Conception ..." [metes and bounds given] “. . . N 2 ${ }^{\circ} \mathrm{E} 52$ varas [144.4 ft], this station is about 60 varas [166.6 ft] W. of the S.W. corner of the Church at the Mission Concepción thence N $811^{1 / 4^{\circ}}$ W. $57 \frac{1}{4}$ varas [160.4 ft] to an old ditch Thence with the ditch as aforesaid as follows; to wit $S 73 \frac{1}{2}{ }^{\circ} \mathrm{W} 49$ varas $[136.1 \mathrm{ft}]$. . ." [remainder of metes and bounds given] (BCDR Vol. A2:430, May 19, 1841).

Appended to the deed are several certifications that showed Garza owned the land sold. One is included here:

"I certify that the land mentioned in the within deed was many years since (on or about the year 1823) conveyed by municipality of Bexar under an order of the Government for the distribution of the Mission land \&.c. to Refugio de la Garza and Gasper Flores the lands contained in the annexed deed, that some six or seven years since, Refugio de la Garza purchased of Gasper Flores his interest in the Said lands, and that it is well known that the title to said land was vested entirely and solely in said Garza. Given under my hand 20th day of May 1841."

Ygn. ${ }^{\circ}$ Chavez

\section{6a. Original Petition of D. Ygnacio Chaves}

Chaves petitions for: "dos dulas de agua en la saca de la abandonada Mision de la Concepción, con su correspondiente tierra de labor en el rincon que llaman del Paso de las Yndias, y molino de Piez . . ." (BCDR Vol. C1:215, October 1823). 


\section{6b. Grant to Ygnacio Chaves}

The grant to Chaves describes the boundaries of the property as follows: "lindando por el Sur con el desagüe; por el Norte donde remata el molino de Piez; por el Oriente con el camino viejo; y por el Poniente con el Río, con su agua correspondiente" (BCDR Vol. C1:218, December 1823; surveyed by district surveyor Francois Giraud and recorded in BCA-CSB Vol. 1:1-2, 7 Dec. 1847).

\section{6c. Partition Between Chávez Heirs}

“. . . Beginning at the old Mill, on the River Bank, from which the Cupola on the Dome of the Mission Church bears South. Thence Southward with an old Road, to the north west Corner of the exterior wall, or Muralla of the Mission, and along said wall running southward, to a corner formed by the same (where it turns to the eastward) in front of the Church, and on the edge of an old quarry-thence westward to the angle of a Desague or Drain . . ." (BCDR Vol. S1:478, Oct. 16, 1860).

The deed continues with survey notes of the divisions into which this land was partitioned. Later transfers of this property define the location of the west wall fairly precisely. See for example: Juan and Antonio Chávez to Charles and Catherina Schiebel (BCDR Vol. W2:130, Sept. 15, 1870); Charles and Catherina Schiebel to E. D. L. Wickes (BCDR Vol. 44:195, Dec. 31, 1885); and E. D. L. Wickes to City of San Antonio (BCDR Vol. 48:583, May 3, 1886; includes plat).

\section{Asa Mitchell to Jacob Ernst}

"Commencing at the S. W. corner of the Survey, a stake set 3 varas [8.33 ft] to the E. side of the road that leads from the Mission of Concepción to that of San José Mission from which the S. W. Penicle of the church of Concepción bears N $13^{\circ} \mathrm{W}$, Thence N $191^{\circ} 2^{\circ} \mathrm{W} 376$ varas [1044 ft] to the old wall of the said Mission yard a stake for a corner from which the S. W. Penicle of the said church bears N $13^{\circ} \mathrm{E}$. Th. N $24^{\circ} \mathrm{E} 80$ varas [222 ft] to the S. W. corner of the Vestry of said church. Th. with the S. Wall of said Vestry at S $85^{\circ} \mathrm{E} 150$ varas [ $416.7 \mathrm{ft}$ ] to the head of the Suerties originally granted to Ramon Musquez Th. S $15^{\circ} \mathrm{W} 155$ varas [430.5 $\mathrm{ft}$ ] . . Thence with a row of large Hackberry trees at S $56^{\circ} \mathrm{E} 344$ varas [955.5 ft] . . for the N. E. corner of this survey Th. S $78^{\circ} \mathrm{W} 305$ varas $[847 \mathrm{ft}$ ] to the place of beginning . . . Containing nearly 14 acres more or less the said tract is bounded on the W. by the old Publick road that leads from the Mission of Concepción to that of San José, on the S. by lands of said Mitchell . . " (BCDR Vol. 12:351, Feb. 20, 1851).

\section{Surveys for the Catholic Church}

Two other deeds of great importance to this study are the surveys of the property of Mission Concepción at the time of their transfer from the Brothers of Mary back to the Bishop of San Antonio. The pastureland west of Mission Road, was surveyed in BCDR Vol. 454:52, May 26, 1911. The mission grounds were surveyed in BCDR Vol. 374:110, July 24, 1911.

Note: The greatest difficulty in fitting all these deed plots together involved crossing Old Mission Road. No two deeds using the notes of different surveyors completely agreed on the actual line of Old Mission Road or of the "desagüe" (drain) running west past the south side of the buildings of Mission Concepción. The best fit was achieved by plotting all the surveys of this area to the same scale, overlaying them, and moving the overlays around until the best compromise of lines of road and ditch were achieved, while maintaining the correct geographic bearing. This procedure indicated that several deeds had errors in them. Some of these errors were corrected by finding other copies of the survey notes, while others could not be so checked. The worst deed of the group was De La Garza and Delmour to Bishop Odin, BCDR Vol. A2:430 (number 5 above), which has several bad calls in the area along the south side of the mission. These were compensated for by using the surveys from adjoining deeds and ignoring the portions of the Garza and Delmour deed which did not fit.

Along the desagüe, the survey notes indicated that there were two different channels which may have been the result of erosion or re-excavation of the ditch. These are indicated on Figure 2 as an open loop above the 
second terrace edge of the river. Below the second terrace was swampy land in an old oxbow of the river, and opinions varied considerably among surveyors as to the route of the desagüe across this area.

In the region just north of the quarry and south of the southwestern corner of the mission enclosure, each surveyor used a different method of going from the corner across the road to the desagüe. What little evidence there is in the contemporaneous plats of this area indicate that the line of the desagüe executed two sharp bends and then continued on east along the south side of the mission, where it intersected the acequia madre near the southeast corner of the mission. This is far from certain, but is the pattern shown by John D. Rullman in his 1912 "Historical Map of Old San Antonio de Béxar," located at the Center for American History, The University of Texas at Austin.

There is no indication that the desagüe crossed the enclosure of the later pueblo compound, while there is a statement that it crossed the early pueblo compound. Since the early compound would appear to have been south of the later compound, a desaguie line south of the later pueblo would probably have passed through the approximate center of the early pueblo, and would have been about where it is indicated in Figure 2 . Until more archaeology is done or new deed information becomes available, this is the best approximation that can be made for the location of this desagüe in the area directly south of the mission. 


\title{
Appendix Ia \\ Molino De Piez
}

\author{
James E. Ivey
}

In the process of conducting the deed research necessary to plot the outline of Mission Concepción's pueblo, a found a reference was found to "the Old Mill" on the Chaves land. It was on the east bank of the San Antonio River about 1200 feet north of the north wall of the pueblo (see Figure 2, and the Chaves deed, Appendix I, no. 6). Further references to this mill were seen in other documents consulted as research and writing continued. It became apparent that this mill must date from the late Colonial or Mexican periods (between 1778 and 1823) and might well be directly associated with Mission Concepción. A brief assessment of this structure is presented here.

The mill is referred to as the "Molino de Piez" in the Chaves petition for the land west of Mission Concepción (BCDR Vol. C1:214-218, Dec. 1823). This deed is recorded as a typed transcript, and the manuscript original of the deed book has not yet been made available to permit a check on the correctness of the word "piez."

In 1847, Francois Giraud, the surveyor for San Antonio and the District of Bexar, surveyed the Chaves land and used the mill as one of his landmarks. He refers to it in his notes: "Beginning at the Cuba [tank] or well-hole of the old stone mill, at the bend of the River San Antonio ..." (BCA-CSB Vol. 1:1-2). This statement that the mill had a cuba, or well-hole, tells us that it was probably similar in design to the mill at Mission San José.

At Mission San José, the mill was driven by water from a funnel-shaped reservoir or well-hole with an approximately 12-foot drop. The mill was located on the edge of a terrace of the San Antonio River valley so that this drop would be available. The reservoir was fed at the top by a branch from the main acequia of San José.

The "Molino de Piez" was apparently located on the edge of a similar river terrace. Traces of a branch labeled "old ditch," apparently running from the original line of the main Concepción acequia to the location of this mill, are indicated on a plat of property north of the mission (BCA-DSB Vol. A9:64, 20 Dec. 1863).

The similarities of construction, powering, location, and the fact that the mill was built prior to 1823 argue that it may have been constructed at the same time as the mill at San José, ca. 1790 (Habig 1968:103). The construction of the San José mill was part of the attempt to bring the growing and grinding of wheat to the mission communities of San Antonio by the Zacatecans beginning in 1778 (Morfi 1935:229-30).

The best estimate for the present location of the site of this mill is directly west of the Reforma Cafe, just south of Interstate Highway 10 and just west of the old line of Mission Road before it was changed to go under IH-10 on its present route. This area was an amusement park in the 1950s and 1960s, and the remains of this park have recently been cleared in preparation for a parking lot. It is likely amusement park and the more recent clearing have not damaged the remains of the mill-some parts could extend 9-10 feet below the present ground surface.

If this was a flour mill built for Mission Concepción about 1790, as seems likely, it should be an important part of the mission structures. 


\section{References Cited}

Habig, M. A.

1968 The Alamo Chain of Missions, A History of San Antonio's Five Old Missions. Franciscan Herald Press, Chicago.

Morfi, Fr. J. A. de

1935 Viaje de Indios y Diario del Nuevo Mexico. Con una introducción biobibliográfica y Acotaciones por Vito Alessio Robles. Segunda edición, con adiciones, de la impresa por la Sociedad "Bibliófilos Mexicanos." José Porrúa e Hijos. Mexico. 


\section{Appendix II \\ The Spanish Trigger Guard}

The following analysis and discussion has been provided by Jay C. Blaine, who has had considerable experience in the identification of Spanish and French arms from archaeological sites in Texas and Oklahoma. The following is quoted from his personal letter of June 8, 1982, written after examination of detailed slides of the object.

"This is certainly part of a Spanish escopeta trigger guard. The quality would appear to be average, good but not fine, and the origin civilian, not military. The general form places it well within the 18th century. I don't believe it could pre-date 1700 in this form. To tighten it farther, I doubt the particular pattern and mode of decoration would be viable past mid-century on an escopeta of the inferred grade. The design is basically a grotesque mask, deeply incised, with punch stippled background and executed in relatively coarse fashion. Many versions of such 'masks' were in vogue for European firearms decoration by 1650 but I haven't found a usefully similar example to your piece from Concepción. As a decoration I believe it very likely reflects the well known Iberian conservatism, particularly as rendered in the provinces. I can't be sure from the slides but I believe the basic design was cast into the bow, in low relief, then detailed by chasing (chiseling) and finally gilded for finish. It looks like the bow itself may be brazed or silver soldered at the juncture with the rear tang

"In any case the execution seems to be of apprentice quality rather than that of a master and the guard likely to be the work of a Spanish provincial mount-producing shop which supplied gunsmiths ...

"You probably have part of a non-military shoulder gun of good average quality. Probably the escopeta is of the light musket-shotgun category and quite suitable for an officer or merchant, someone of above the ranks status who is serving out on the frontier and wouldn't want to subject a really fine and expensive gun to the rigors of such service (Blaine 1982)."

A virtually identical trigger guard is illustrated in Simmons and Turley 1980, page 149, plate 27. This is described as "from the site of the San Diego Presidio, late eighteenth and early nineteenth centuries." In the description of the trash pit in which the trigger guard was found at Mission Concepción, it was indicated that the filling of the pit probably began soon after 1731. The last material in the pit, including the gun parts, could have been dumped there as late as 1757, when the construction of the final Pueblo began. A disposal date for the trigger guard of about 1750 would accord well with Blaine's implied date of manufacture of about 1730-1750. The trigger guard from San Diego Presidio, which was established in 1769, would then appear to have been curated for several decades before it was discarded.

It is believed that the weapon from which the Concepción trigger guard came may have belonged to a soldier stationed at the mission, a secular visitor, or one of the missionaries. That this is not too unlikely a possession for a missionary is indicated by remarks made by Fray Juan Morfi at the time of his visit to Mission San José in 1778. While describing how the second story corridor of the convento of San José opened out onto the roof of the first story, he added:

"From this flat roof one can hunt without hazard, with good and sufficient success; because there live in a nearby field so many ducks, geese and cranes that, so to speak, they cover the earth, and so close to the convento that it would be impossible to miss the shot" (Morfi 1935 :227).

Morfi makes a number of other observations about hunting in his diary, enough so that the reader is left in no doubt that he was an avid hunter. From this it would appear that it was not considered unsuitable for a Franciscan missionary to hunt on occasion. 


\section{References Cited}

Blaine, J. C.

1982 Personal letter of June 8, 1982.

Morfi, Fr. J. A. de

1935 Viaje de Indios y Diario del Nuevo México. Con una introducción biobibliográfica y Acotaciones por Vito Alessio Robles. Segunda edición, con adiciones, de la impresa por la Sociedad "Bibliófilos Mexicanos." José Porrúa e Hijos, Mexico.

Simmons, M. and F. Turley

1980 Southwestern Colonial Ironwork. Museum of New Mexico Press, Santa Fe. 


\section{Appendix III \\ Faunal Analysis}

William McClure and James E. Ivey

\section{Introduction}

Faunal identification was carried out by McClure on two separate midden deposits-acequia fill and a trash pit-found in units $9,26,27$, and 28 . The two deposits were partially superimposed features (Table III-1)

Table III-1: Units and Levels of Midden Deposits

\begin{tabular}{|c|c|c|c|}
\hline \multicolumn{2}{|c|}{$\begin{array}{l}\text { Apparent Acequia } \\
\text { filled before } 1730 \text { s }\end{array}$} & \multicolumn{2}{|c|}{$\begin{array}{c}\text { Trash pit, } \\
\text { ca. } 1731-1740 \\
\end{array}$} \\
\hline \multirow[t]{3}{*}{ Unit } & Level & Unit & Level \\
\hline & & \multirow[t]{2}{*}{9} & 9 \\
\hline & & & 10 \\
\hline \multirow[t]{4}{*}{26} & 11/RH-1 & \multirow[t]{4}{*}{26} & 9 \\
\hline & 11/RH-2 & & 10 \\
\hline & 12 & & \\
\hline & 15 & & \\
\hline \multirow[t]{2}{*}{27} & 12 & \multirow[t]{2}{*}{27} & 9 \\
\hline & 13 & & 10 \\
\hline \multirow[t]{3}{*}{28} & 9 & & \\
\hline & 12 & & \\
\hline & $1^{-}$ & & \\
\hline
\end{tabular}

These deposits can be seen in the profile of Unit 27 shown in Figure 9, Items 2 and 3. In this figure, the trash pit fill occupies all the area from the stratum labeled "brown, sandy clay, charcoal, bone" (Stratum 27/9) to the strata labeled "ash" (Stratum 27/11). The undescribed layer between these two is Stratum $27 / 10$. In the apparent acequia, the topmost layer, labeled "black blocky clay" is Stratum 27/12*, while the next layer, "dk. brown sand and clay," is Stratum 27/13. The faunal analysis indicates that some mixing of materials from the two deposits occurred at the interface between 27/12 and the upper layers of the trashpit, $27 / 9$ and $27 / 10$. This is most likely the result of cutting into the edge of the acequia deposits at the time the trashpit was excavated in the early $1730 \mathrm{~s}$.

The acequia fill contains very few artifacts besides bone. One fragment of colonial brick, several lithic fragments, 69 sherds and one lump of melted lead from 27/12 make up the majority of these. Only the colonial brick and the lump of lead can be attributed to Spanish manufacture.

This faunal analysis includes a species inventory, provenience lists and counts, a discussion of bone modifications, and a review of the archaeological context of the bone. 


\section{Faunal List}

Scientific Name

Fish:

Lepisosteus spatula

Ictalurus punctatus

?

\section{Amphibians:}

Bufo sp.

Rana sp.

Reptiles:

Crotalus atrox

Chrysemys sp.

Terrapene sp.

Trionyx sp.

?

\section{Birds:}

Meleagris gallopavo

Gallus domesticus

Icterus sp.

Turdus migratorius

?

?

\section{Mammals:}

Sigmodon hispidus

Neotoma sp.

Geomys sp.

Sciurus niger

?

?

?

Sylvilagus sp.

Procyon lotor

?

$?$

Capra hirca

?

Odocoileus virginianus

Equus sp.

\section{Common Name}

\author{
Alligator gar \\ Channel catfish \\ Unidentified fish
}

Toad

Frog

Diamondback rattlesnake

Pond turtle

Box turtle

Unidentified turtle
Turkey

Chicken

Oriole

Robin

Hawk

Unidentified bird
Hispid cotton rat

Wood rat

Pocket gopher

Fox squirrel

Unidentified rodent, squirrel size

Unidentified rodent, rat size

Unidentified rodent, mouse size

Cottontail rabbit

Raccoon

Unidentified mammal, fox size

Unidentified mammal, skunk size

Domestic goat

Bison or cow

White-tail deer

Fossil horse

Unidentified animals 


\section{BX12 Mission Concepción Trash Pit}

Faunal Analysis (Unit/Level; * indicates acequia deposits)

Fish:

Alligator gar, Lepisosteus spatula. At least two individuals with length from 90 to $100 \mathrm{~cm}$. One scale, two vertebrae, two parasphenoids, one other head bone. Units $9 / 10$ and 27/10.

Channel catfish, Ictalurus punctatus. At least two individuals with length from 40 to $50 \mathrm{~cm}$. Two vertebrae, two left pectoral spines, one cleithrum, three other head bones. Units $26 / 10,26 / 11$, and 27/10.

Unidentified fish. Eighteen bones from anterior part of fish. Units 26/11, 26/11/RH-1, 26/13, 27/9, and 27/10.

Amphibians:

Toad, Bufo sp. One femur. Unit 9/10.

Frog, Rana sp. One tibio-fibula. Unit 26/10.

Reptiles:

Diamondback rattlesnake, Crotalus atrox. One individual at least one meter long. Assigned to this species as there was no other rattlesnake of this size in immediate area. One vertebra. Unit 27/10.

Pond turtle, Chrysemys sp. At least two large individuals. Nine bones from carapace. Units $26 / 9$ and $26 / 15^{*}$.

Box turtle, Terrapene sp. Two bones from carapace. Item from unit 27/10 is burned. Units 27/9 and 27/10.

Softshell turtle, Trionyx sp. One bone from carapace. Unit 26/14.

Unidentified turtle. Nine appendicular and 11 carapace bones. Carapace bone from 27/10 is burned. Units $26 / 10,26 / 11,27 / 9$, and 27/10.

Birds:

Turkey, Meleagris gallopavo. At least four individuals of three sizes. Twenty-eight bones including vertebrae, humeri, scapulae, ulna, femora, tibiotarsi, ribs, and phalanges. Units 26/9, 26/10, 26/11, 26/11/RH-1, 26/14, $27 / 9$, and $27 / 10$.

Chicken, Gallus domesticus. One adult of small size. Tibiotarsus. Unit 27/10.

Oriole, Icterus sp. One individual. Humerus. Unit 26/11.

Robin, Turdus migratorius. One individual. Humerus. Unit 27/9.

Hawk, Genus unknown. One individual. Two ulnae. Units 26/9, 27/10, and 27/12*.

Unidentified bird. One individual smaller than a chicken. First phalanx of second digit of wing. Unit 27/11. 
Mammals:

Hispid cotton rat, Sigmodon hispidus. At least four individuals. Forty-five bones including teeth, mandibles, scapula, innominates humeri, ulna, femora, tibiae. Units 26/10, 26/11, 26/14, 27/9, 27/10, and 27/11.

Woodrat, Neotoma sp. At least four individuals. Twenty-six bones including teeth, maxilla fragments, mandibles, humeri, ulnae, tibiae, and femur. Units 9/10, 26/11, 26/14, 27/9, 27/10, and 27/11.

Pocket gopher, Geomys sp. At least two individuals. Three upper incisors, scapula. Units 26/9 and 27/10.

Fox squirrel, Sciurus niger. At least two individuals. Femora. Units 26/11 and 27/9.

Unidentified rodent. At least six individuals, squirrel size. Thirty-one bones including scapulae, femora, tibiae, vertebrae, and innominates. Units 9/10, 26/9, 26/11, 26/11/RH-1, 27/9, 27/10, 27/11, and 28/9*.

Unidentified rodent. At least six individuals, rat size. Forty-four bones including teeth, scapulae, humeri, radii, ulnae, femora, tibiae, and calcanei. Units 9/9, 26/9, 26/10, 26/11, 26/13, 26/14, 27/9, 27/10, 27/11, and $27 / 12 *$.

Unidentified rodent. At least two individuals, mouse size. Four bones including teeth, radius, and ulna. Units $9 / 10,26 / 14$, and $27 / 11$.

Cottontail rabbit, Sylvilagus sp. At least six individuals from subadult to arthritic old. One hundred twenty-three bones including teeth, mandibles, maxillae, vertebrae, humeri, innominates, femora, scapulae, tibiae, calcanei, astragalus, metatarsalia, metacarpalia, phalanges, radii, and ulnae. Units 9/10, 26/10, 26/11, 26/11/RH-1, $26 / 13,26 / 14,27 / 9,27 / 10$, and $27 / 11$.

Raccoon, Procyon lotor. One lower molar M-1. Unworn permanent tooth. Unit 27/9.

Unidentified mammal. One lower canine tooth. Matches gray fox, Urocyon cineroargentatus. Unit $27 / 9$.

Unidentified mammal. Fragment of mandible without teeth. Size of skunk, Mephitis sp. Unit 27/10.

White-tailed deer, Odocoileus virginianus. At least four individuals from subadult to old. About half of the bones are larger than bones from deer now living in Bexar County. They more closely match deer from the Rio Grande Plain about $100 \mathrm{~km}$ to the south. One hundred one bones including teeth, occiput, maxillae, mandibles, vertebrae, ribs, scapula, humeri, radii, ulnae, femora, tibiae, metatarsalia, astragali, calcaneus, all three phalanges, trapezium magnum, cuneiform, scaphoid, and centroquartalia. Units 26/9, 26/10, 26/11, 27/9, $27 / 10$, and $27 / 12 *$.

Domestic goat, Capra hirca. At least three individuals. Twelve bones including axis and three adjacent vertebrae, ulna, astragalus, phalanx, and three trapezia magna. Units 27/9 and 27/10.

Large bovid, either Bison bison or Bos taurus. At least four individuals. This material was compared to the bones of an average-sized female range cow. Two individuals are much larger and more robust than the cow, and two are smaller young adults. Several of the vertebrae had centra that were shorter than those of the cow with heavier neural spines and other processes. The angle between the rami of the mandible is less than in the cow. None of these characteristics is sufficient to determine whether the material represents cow or bison or both. One hundred nine bones including mandibles, vertebrae, ribs, humeri, radius, ulnae, metacarpal, trapezium magnum, all three phalanges, scapulae, femur, tibiae, patellae, metatarsal, astragali, sternum, innominates, and skull. Units $9 / 9,26 / 9,26 / 10,26 / 11,26 / 12^{*}, 26 / 13,26 / 14,26 / 15^{*}, 27 / 9,27 / 10,27 / 11$, 
$27 / 12 *, 27 / 13,28 / 9 *, 28 / 12 *$, and $28 / 13^{*}$. The larger and smaller material was mixed within the units, but most of the smaller material came from Units $27 / 9,27 / 12^{*}, 28 / 9 *$, and $28 / 12^{*}$.

Extinct horse, Equus sp. One lower premolar tooth, P-4. This is a mineralized fossil. Unit $27 / 9$.

Unidentified animals. There are numerous bones from the excavation that cannot be assigned to any particular animal. The total volume is about equal to that of the identifiable material. These are mostly fragments of bones that are most likely deer, goat, and large bovid. There are also fragments of bones of smaller animals. Units 9/9, 9/10, 26/9, 26/10, 26/11, 26/11/RH-1, 26/11/RH-2, 26/12*, 26/13, 26/14, 26/15*, 27/9, 27/10, 27/11, $27 / 12^{*}, 27 / 13,28 / 9 *, 28 / 12^{*}$, and $28 / 13^{*}$.

\section{Bone Modification}

Most of the bones are in fair condition. Many of them show the usual cracks and splits from changing soil conditions and age. Most show some modification of surface due to chemical action in the soil. Some of the bones have been burned and it appears that much of the burning occurred after deposition.

The presence of numerous rodent bones and the near absence of gnaw marks suggest that the discarded bones may not have been exposed very long. The presence of teeth, still in their bone sockets, is an indication that the discard was not into the canal while it had standing water. The only indication of possible scavenger activity is a phalanx of a deer. This bone had been perforated from opposing sides in a manner that suggests canine teeth.

Four pleural bones of the carapace of a pond turtle from Unit 26/9 have several transverse striations that may indicate cutting action. The ribs had been removed, and the shell had probably been used as a container.

Of the bones of turkey, rabbit, deer, goat, and large bovid, only the smaller, more compact elements are still intact. Some of the breakage may have occurred after deposition and some obvious breakage happened during recovery and transport. However, most of the breakage appears to have been due to impact with hard objects, probably for marrow extraction. In addition, many of the bones of deer and large bovid exhibit marks that give some indication of tools used during processing by the occupants of the mission.

Some bones have one or more straight narrow cut marks that are indicative of use as a sharp-edged tool, such as a flint flake or metal knife. These are usually located near joints or points of muscle attachment and probably represent efforts to remove hide or tissue. One deer rib has 14 such marks irregularly spaced on the outer edge. A deer metatarsal also has an X mark at midshaft. These cut marks are on turkey ulna from Unit 27/9; deer ribs, vertebra, metatarsal, humerus, tibia, femur, and calcaneum from Units 26/9, 26/11, 27/9, 27/10, and $27 / 12^{*}$; large bovid ribs, vertebra, sternum, tibia, scapula and innominate from Units $26 / 9,26 / 10,26 / 15^{*}$, 27/9, and 27/10; unidentified mammals (cf., deer or bovid) from Units 26/10, 26/11, 26/11/RH-1, 26/11/RH-2, 27/9, 27/10, and 27/11.

Several bones have one or more U- or V-shaped chop marks that are as wide as deep, and probably were attempts to break the bones. The shape of the marks suggests the use of a flint biface. Some were dull and others were sharp. These chop marks are on bovid mandible, vertebrae, ribs, and tibia from Units 26/10, 27/9, and 27/10; unidentified mammals were from Units 26/9 and 27/9. Similar chop marks that appear to have been made by flint unifaces are on bovid innominate and vertebra from Units $26 / 9$ and $26 / 15^{*}$.

Several bones have straight narrow-sided marks that probably were made by a metal hatchet. The bit had a straight cutting edge and was $29 \mathrm{~mm}$ long where the entire mark was preserved. Some marks show that the 
hatchet was not sharpened as often as needed. These hack marks are on bovid vertebrae, ribs, and innominates from Units $26 / 10,26 / 11,27 / 9,27 / 10$, and 28/12*; unidentified mammals from Units 26/10 and 27/10.

One bovid vertebra was cut completely through at about $15^{\circ}$ from the right angle. The cut is fairly straight as though a knife were driven through the centrum, neural spine, and lateral process. There are no saw teeth marks. Other bovid vertebrae were hacked or chopped on either the centrum or the neural spine, both from the underside. This effort was apparently for the purpose of removing the hump of flesh above the backbone as well as cutting the backbone into smaller pieces.

Also, a great effort was expended in breaking the innominates into smaller pieces. Multiple marks are on both sides of the bone as well as on the acetabulum, after removal of the femur.

One bovid neural spine from Unit 26/11/RH-1 and an unidentified larger bone fragment from Unit 26/11 have numerous light striations, closely spaced, nearly parallel. These marks resemble those found on a cutting board.

\section{Discussion}

Nearly $12 \mathrm{~kg}$ of bones and bone fragments removed from the dump were examined. Identification was made as far as possible with use of the Houston Archaeological Society comparative bone collection as well as several references. Some elements that would not have been identifiable alone were assumed to be from the known animals. Each bone was examined for evidence of modification.

The presence of one element each of frog, toad, rattlesnake, raccoon, and unidentified medium-sized mammals indicates little more than that they were in the environment. Catfish and gar were used as food, and the edible portions were processed elsewhere. Turtles were used as food and perhaps as utensils.

The single chicken bone may represent the earliest indication of importation of this fowl into Texas. Four other birds are represented only by wing bones: The number and variety of rodents and the absence of gnaw marks on other bones support the indicated use as food of the available small animals.

Turkey, rabbit, deer, goat, and large bovid were very important food resources for the inhabitants. The presence of various age classes in turkey and bovid suggest harvest of wild stock. However, two of the bovid individuals were butchered at a young adult age, which could indicate domestic stock. Perhaps both bison and cow are in the material. Antlers and horn cores are not represented in the assemblage, and this may indicate that they were used rather than discarded.

The fossil horse tooth demonstrates that the inhabitants picked up curious objects as do modern people.

The two pieces of the same hawk ulna were found in Units $27 / 10$ and $27 / 12^{*}$, while the matching ulna came from Unit 26/9. An epiphysis of a bovid tibia from Unit $27 / 12 *$ fits the tibia from Unit $27 / 9$. Two halves of the end of a bovid radius came from Units $26 / 9$ and 26/10. In view of these matching elements, it is probable that Units $26 / 9,26 / 10,27 / 9,27 / 10$, and $27 / 12^{*}$ have the same depositional history. An epiphysis of a bovid tibia from Unit $28 / 12 *$ fits the tibia from $28 / 9 *$, and these two units probably have similar depositional history.

The inhabitants of the mission used stone and metal tools for butchering the larger animals. There is no discernable change from stone to metal tools in the stratigraphic sequence.

From the faunal record there is little to differentiate the cultural activities of the earlier from the later occupation. Stratigraphically, the earlier period is represented by Units $26 / 12^{*}, 26 / 15^{*}, 27 / 12^{*}, 27 / 13,28 / 9^{*}$, $28 / 12^{*}$, and $28 / 13^{*}$. The hawk ulnae equate unit $27 / 12^{*}$ and the later units. The possible cow tibia from Units 
$28 / 9 *$ and $28 / 12 *$ suggests use of domestic stock at an early date. A metal hatchet was probably used on the bone from Unit $28 / 12^{*}$. The only difference that can be attributed to the earlier units is the absence of smaller animals. This may indicate discard of such refuse elsewhere rather than nonuse of the resource.

\section{Conclusions}

As can be seen in Table III-2, the predominant faunal material in the acequia deposit was bovid, with some whitetailed deer and a very few other bones, mostly rodents of several kinds-which probably represent accidental inclusion. The hawk ulna is apparently present as the result of downward mixing from $27 / 10$, where the other half was found. The pond turtle may also have arrived in the deposits by accident rather than human action. We hesitate to suggest that it is there as the result of having died while an occupant of the acequia when it still contained water, before it began to be filled with debris. Since, however, it was found in one of the lower levels of the acequia, such a happenstance is possible.

This distribution is rather an odd result. It can be taken to indicate that the acequia fill consists almost entirely of the butchering and kitchen debris from deer and bovids. The trash pit contains a large amount of similar food debris, virtually all the other species bones and, in addition, a great deal of random trash. In other words, the fill in the acequia seems to be only from the food preparation of deer and bovids, with almost no Spanish presence seen in its artifacts, while the trash pit is a catchall for trash from a much wider range of activities, with a strong Spanish presence.

It should be noted that the material recovered from the apparent acequia in Unit 42 was more like the trash pit fill discussed above in the variety of artifacts it contained, even though the date implied by these artifacts is prior to 1730 . The acequia segment seen in Unit 42 , then, was probably filled by the same kind of trash-collection and dumping process that filled the post-1731 pit seen in Units 9, 26, and 27. The Spanish presence in the dumped material in Unit 42 is also very strong. In Unit 45, the lower stratum contains a great quantity of butchered bone, predominantly bovid and dating prior to ca. 1760 , which is the equivalent of the bone fill of the acequia seen in units 26,27 , and 28 . This leads to a very general supposition: in the first occupation of this site, apparently before 1731 , the food preparation activities occurred principally near the northeast corner of the site, while trash dumping took place towards the southwestern side. After 1731, the situation was reversed. The Spanish were present during both periods of deposition.

If the early occupation was missionary-induced, as the later was, and if the trash dumps containing Spanish material were most closely associated with the church and convento, as the later was, then the church and convento of the early occupation should be in the general area of the southwestern corner of the site. This is a conjecture based on very limited evidence, but future archeological and site development planning should certainly take this possibility into account. The planned realignment of Mission Road to its earlier location must allow sufficient archaeology to examine the area north and northwest of the Quarry. The acequia line itself will be relatively easy to follow if it continues as clearly defined as it was in the area of Unit 42, and structural remains such as jacal construction trenches and stone foundations (if present) should have gone deep enough to have survived the scraping of this area. They would not survive the construction of a modern road. 
Table III-2: Distribution of Species in Middens

\begin{tabular}{|l|c|c|}
\hline Species & Acequia & Trash pit \\
\hline \hline Alligator gar & & $\mathrm{X}$ \\
\hline Channel catfish & & $\mathrm{X}$ \\
\hline Unidentified fish & & $\mathrm{X}$ \\
\hline Toad & & $\mathrm{X}$ \\
\hline Frog & & $\mathrm{X}$ \\
\hline Diamondback rattlesnake & & $\mathrm{X}$ \\
\hline Pond turtle & $\mathrm{X}$ & $\mathrm{X}$ \\
\hline Box turtle & & $\mathrm{X}$ \\
\hline Softshell turtle & & $\mathrm{X}$ \\
\hline Unidentified turtle & & $\mathrm{X}$ \\
\hline Turkey & & $\mathrm{X}$ \\
\hline Chicken & & $\mathrm{X}$ \\
\hline Oriole & & $\mathrm{X}$ \\
\hline Robin & & $\mathrm{X}$ \\
\hline Hawk & & $\mathrm{X}$ \\
\hline Unidentified bird & $\mathrm{X}$ & $\mathrm{X}$ \\
\hline Hispid cotton rat & & $\mathrm{X}$ \\
\hline Wood rat & & $\mathrm{X}$ \\
\hline Pocket gopher & & $\mathrm{X}$ \\
\hline Fox squirrel & & $\mathrm{X}$ \\
\hline Unidentified rodent, squirrel & & $\mathrm{X}$ \\
\hline Unidentified rodent, rat size & & $\mathrm{X}$ \\
\hline Unidentified rodent, mouse size & & $\mathrm{X}$ \\
\hline Cottontail rabbit & & $\mathrm{X}$ \\
\hline Raccoon & & $\mathrm{X}$ \\
\hline Unidentified mammal, fox size & & $\mathrm{X}$ \\
\hline Unidentified mammal, skunk & & $\mathrm{X}$ \\
\hline Domestic goat & & $\mathrm{X}$ \\
\hline Bison or cow & & $\mathrm{X}$ \\
\hline White-tailed deer & & $\mathrm{X}$ \\
\hline Fossil horse & & $\mathrm{X}$ \\
\hline Unidentified animals & & $\mathrm{X}$ \\
\hline
\end{tabular}




\section{Appendix IV \\ Burial Fabric Analysis}

Anne A. Fox and James E. Ivey

Three fabric samples were recovered during the exposure of Burial 1 in Unit 22. This was determined to be an infant buried ca. 1757. The fabric samples were examined by Fox under a binocular microscope ( $80 \mathrm{X}$ and $160 \mathrm{X})$, and the following observations were made.

All actual fiber has disappeared, but a mineral cast of each strand remains, giving an appearance of preserved fabric. The cast impressions are detailed enough to allow identification of the fiber. In the case of Sample 2, apparently some of the dye from the fiber was absorbed into its mineral cast. The fibers in Sample 3 were found to be too badly distorted to be identifiable.

Table IV-1: Burial Fabric Analysis

\begin{tabular}{|l|l|l|l|l|l|l|}
\hline Sample & Fiber & Spin & Twist & Ply & Color & Size \\
\hline \hline \multirow{2}{*}{$\begin{array}{c}\text { No.1. (warp) } \\
\text { (weft) }\end{array}$} & wool & $\mathrm{Z}$ & & 1 & off-white & \multirow{2}{*}{$2.5 \times 3 \mathrm{~cm}$} \\
\cline { 2 - 7 } & wool & $\mathrm{Z}$ & & 1 & off-white & \\
\hline \multirow{2}{*}{$\begin{array}{c}\text { No. 2. (weft) } \\
\text { (no warp preserved) }\end{array}$} & wool & $\mathrm{S}$ & $\mathrm{Z}$ & 2 & pink & \multirow{2}{*}{$0.6 \times 0.2 \mathrm{~cm}$} \\
\cline { 2 - 7 } & wool & $\mathrm{Z}$ & & 1 & off-white & \\
\hline
\end{tabular}

\section{Conclusions}

Of the two samples described above, the first was more complete. The fabric was made of plain-woven (over one, under one) homespun wool, which one would expect to find during the proposed burial period. The counts of the weave were 12 warp threads and 20 weft to the inch.

The second fabric, of which a much smaller sample was collected, appears to be a more complex weave, possibly a twill (over two, under one) done with alternating weft threads of pink and white. The denier was much the same as that of the first fabric. Such a blanket would not be an unusual part of a baby's wardrobe to this day.

When relatively intact in the ground, the third fabric was observed to be off-white and of a noticeably finer denier than the first two samples. The general appearance was similar to a coarse cotton or linen cloth.

The infant appeared to have been wrapped loosely in the three varieties of cloth. The innermost layer was the fine cotton-like cloth, Sample 3. The next layer was the pink cloth, Sample 2, and Sample 1 was from the outer layer of coarse, whitish cloth. Mission records indicate that at least the outermost fabric, Sample 1, was probably made in the nearby weaving room of Mission Concepción, and perhaps Sample 2 also. Sample 3 may have been imported from Mexico in the annual supply train. Leutenegger (1976:24-29) gives a good discussion of which sorts of cloth were used for what purposes at Concepción. 
The finding of fabric samples in Mission period burials in Texas is extremely rare. At Mission San Lorenzo one small fragment of fine-woven linen was found, preserved against a religious medal in Burial 4 in the church (Tunnell and Newcomb 1969:60, Figure 29,e). At Mission San Juan, Schuetz (1969:45, Plate 21, A,H) found several fragments of cloth of a similar weave adhering to religious objects in burials, but she did no analysis of the weave or composition. Any future cloth samples found in mission burials should be analyzed carefully for weave and fiber. At the same time, an intensive study should be done of the weaving procedures and equipment referred to in the reports, inventories, and invoices of the San Antonio missions, and of the quantities and varieties of cloth ordered each year as listed in the invoices. The terminology used would be intelligible to one well versed in weaving and cloth manufacture. Such a study would yield a considerable amount of information on trade networks and the mission economic system, as well as otherwise inaccessible data on mission clothing practices.

\section{References Cited}

Leutenegger, Fr. B.

1976 Guidelines for a Texas Mission. Instructions for the Missionary of Mission Concepción in San Antonio. Old Spanish Missions Historical Research Library at San José Mission, San Antonio, Texas.

Schuetz, M. K.

1969 The History and Archeology of Mission San Juan Capistrano, San Antonio, Texas (Vol. 2). Description of the Artifacts and Ethnohistory of the Coahuiltecan Indians. Archeological Program Report, No. 10. State Building Commission, Austin

Tunnell, C. D. and W. W. Newcomb, Jr.

1969 A Lipan Apache Mission, San Lorenzo de la Santa Cruz, 1762-1771. Bulletin No. 14. Texas Memorial Museum, Austin. 
Appendix V

Artifact Tables 
Table V-1. Artifacts from Granary Area, Blocks I, II, III, and IV

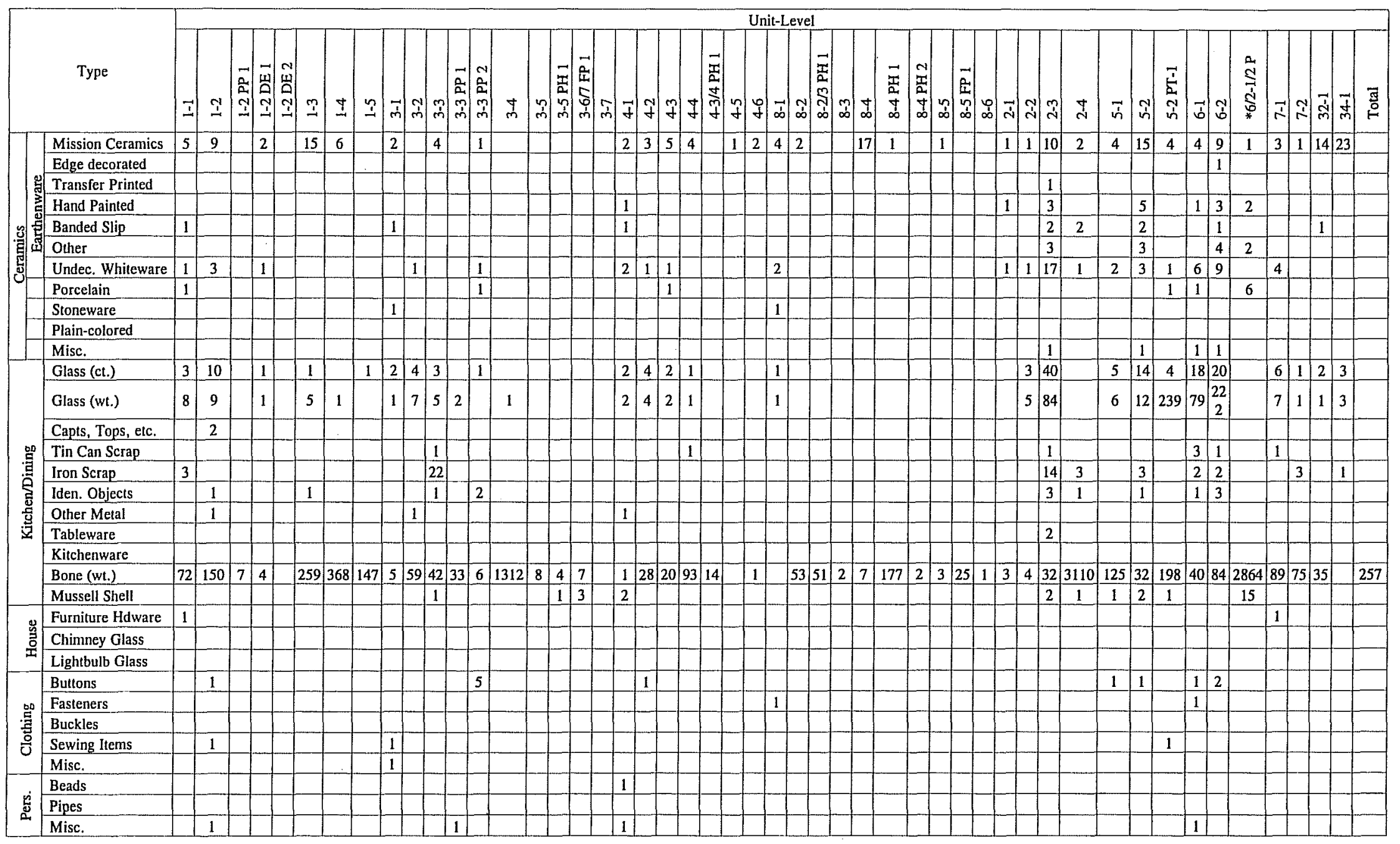


Table V-1. continued

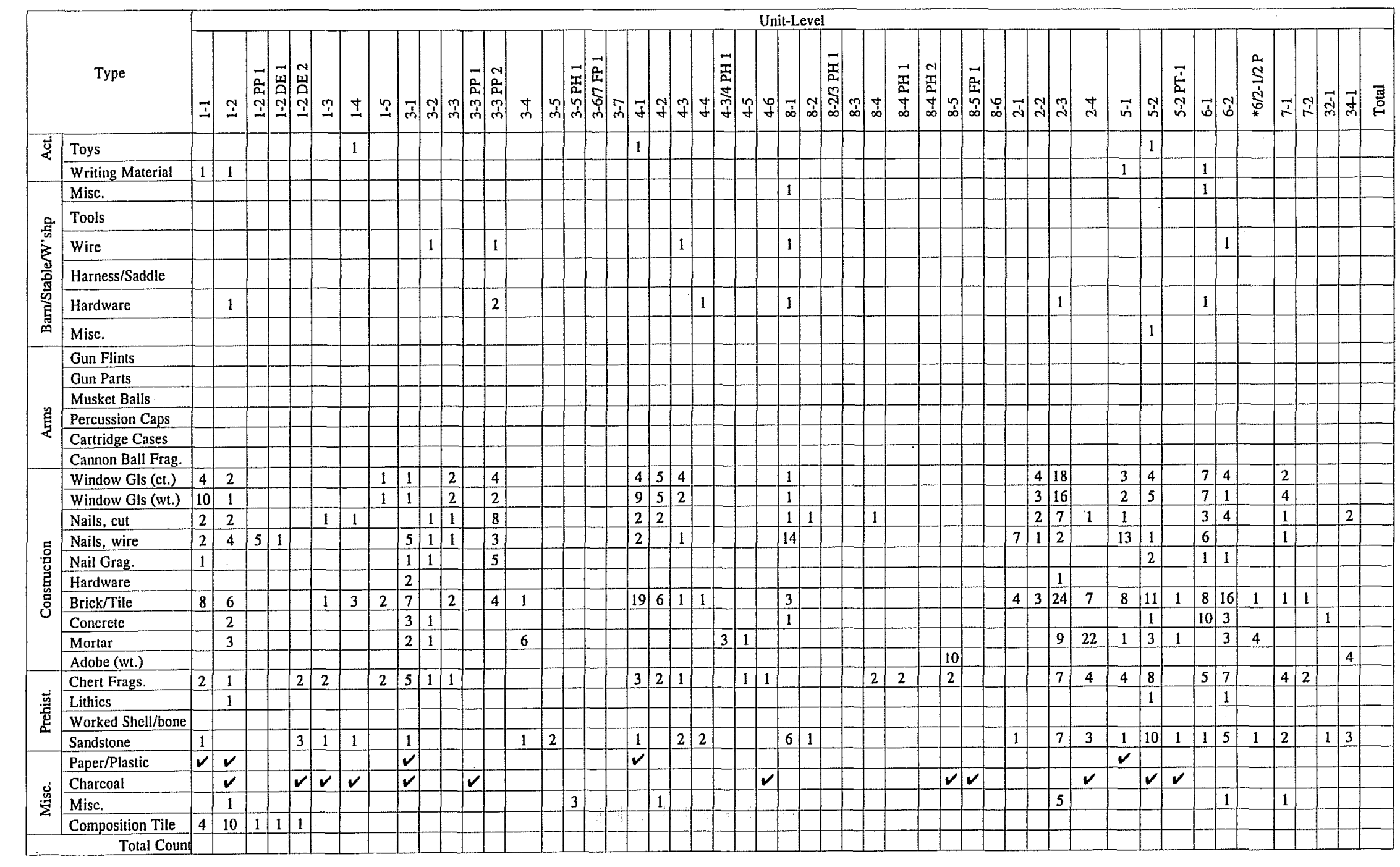


Table V-2. Ceramics from the Granary Area, Blocks I, II, III, and IV.

\begin{tabular}{|c|c|c|c|c|c|c|c|c|c|c|c|c|c|c|c|c|c|c|c|c|c|c|c|c|c|c|c|c|c|c|c|c|c|c|c|c|c|c|}
\hline \multirow{3}{*}{\multicolumn{2}{|c|}{ Levels }} & \multicolumn{22}{|c|}{ Block I } & \multicolumn{12}{|c|}{ Block II } & \multirow{3}{*}{\begin{tabular}{|c|} 
Blk III \\
Ut 32 \\
1 \\
\end{tabular}} & \multirow{3}{*}{\begin{tabular}{|c|} 
Blk IV \\
Ut 34 \\
\\
\\
\end{tabular}} & \multirow[b]{3}{*}{ Total } \\
\hline & & & & \multicolumn{6}{|c|}{ Unit 1} & \multicolumn{3}{|c|}{ Unit 3} & \multicolumn{6}{|c|}{ Unit 4} & \multicolumn{5}{|c|}{ Unit 8} & \multicolumn{4}{|c|}{ Unit 2} & \multicolumn{3}{|c|}{ Unit 5} & \multicolumn{3}{|c|}{ Unit 6} & \multicolumn{2}{|c|}{ Unit 7} & & & \\
\hline & & 咅 & $\vec{u}$ & 1 & 2 & 商 & 莟 & 3 & 4 & 1 & 3 & 空 & 1 & 2 & 3 & 4 & 5 & 6 & 1 & 2 & 4 & 竞 & 5 & 1 & 2 & 3 & 4 & 1 & 2 & 点 & 1 & 2 & 帘 & 1 & 2 & & & \\
\hline$\ddot{Z}$ & Goliad & 1 & 3 & 3 & 5 & & 9 & 11 & 3 & & & & 1 & 1 & 1 & 3 & & 1 & 3 & 2 & 14 & 1 & & 1 & & 4 & & 1 & 1 & & & 4 & & 3 & 1 & 2 & 2 & 81 \\
\hline 5 & Valero & & 3 & & & & 2 & & & & & & & & & & & & & & 2 & & & & & 1 & & & & & & & & & & 2 & 11 & 21 \\
\hline$\vec{d}$ & Blackware & & & & & & & & & & & & & 1 & & & & & & & & & & & & & & & & & & & & & & & & 1 \\
\hline 吾 & Redware & & & & & & & 1 & & 1 & & & & & & 1 & & & & & & & & & & & 1 & & 1 & & & & & & & 2 & 5 & 12 \\
\hline & Tonalá & & & & & & & & & & & & & & & & & & & & & & & & & & & & & & & & & & & & & 0 \\
\hline$y$ & Galera & & & & & 1 & 1 & & & & & & & & 1 & & & & & & & & & & & & & & 4 & & 1 & 2 & & & & & & 10 \\
\hline 留. & Lusterware & & & & & & & & & & & & & & & & & & & & & & & & & & & & & & & & & & & & & 0 \\
\hline 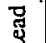 & Olive Jar & & & & & & & & & & & & & & & & & & & & & & & & & & & & & & & 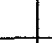 & & & & & & 0 \\
\hline & Sandy Paste & & & & 1 & & & 1 & & 1 & & & & 1 & 3 & & 1 & & 1 & & & & & & 1 & 2 & 1 & & 2 & 4 & 1 & 2 & 1 & & & 6 & & 29 \\
\hline & Aqua Green-on-White & & & & & & & & & & & & & & & & & & & & & & & & & & & & & & & & & & & & & 0 \\
\hline & Blue and Green-on-While & & 1 & 1 & & & & & & & & & & & & & & & & & & & & & & & & & & & & & & & & & & 1 \\
\hline & Blue-on-White & & & & & & 3 & 2 & 2 & & 2 & & & & & & & & & & & & & & & & & 1 & 4 & & 1 & 1 & & & & & 4 & 20 \\
\hline & Blue-on-White Double & & & & & & & & & & & & & & & & & & & & & & & & & & & & & & & & & & & & & 0 \\
\hline & Blue-on-White Molded & & & & & & & & & & & & & & & & & & & & & & & & & & & . & - & & & & & & & & & $\underline{0}$ \\
\hline & Faience & & & & & & & & & & & & & & & & & & & & & & & & & & & & & & & & & & & & & 0 \\
\hline มี & Guanajuato & & & & & & & & & & & & & & & & & & & & 1 & & & & & 1 & & & 1 & & & & & & & & & 3 \\
\hline$\frac{d}{5}$ & Huejotzingo & & & & & & & & 1 & & & & & & & & & & & & & & & & & & & 1 & & & & & & & & & 1 & 4 \\
\hline$\Xi$ & 19th Century Majolicas & & & & & & & & & & & & & & & & & & & & & & & & & & & & & & & & & & & & & 0 \\
\hline & Monterey & & & & & & & & & & & & & & & & & & & & & & & & & & & & 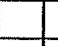 & & & & & & & & & 0 \\
\hline & Orange Band Polychrome & 1 & 1 & 1 & & & 1 & & & & & & 1 & & & & & & & & & & 1 & & & . & & & 2 & & & & & & & & & 6 \\
\hline & Puebla Polychrome & & & & & & & & & & & & & & & & & & & & & & & & & & & & & & & & & & & & & 0 \\
\hline & San Agustín & & & & & & & & & & & & & & & & & & & & & & & & & 1 & & & & & & & & & & & & 1 \\
\hline & San Antonio Blue-on- & & & & & & & & & & & & & & & & & & & & & & & & & & & & & & & & & & & & & 0 \\
\hline & San Elizario & & & & & 1 & & & & & & & & & & & & & & & & & & & & 1 & & & & & & & & & & 1 & & 4 \\
\hline & Tucson Orange Band & & & & & & & & & & & & & & & & & & & & & & & & & & & & & & & & & & & & & 0 \\
\hline & Tumacacori & & 1 & & & & & & & & & & & & & & & & & & & & & & & & & & & & & & & & & & & 1 \\
\hline & White & 1 & & 1 & 3 & & 1 & & & & 2 & 1 & & & & & & & & & & & & & & & & 1 & & & 1 & & & . & & 1 & & 12 \\
\hline & Total & 3 & 9 & 5 & 9 & 2 & 17 & 15 & 6 & 21 & 4 & 1 & 2 & 3 & 5 & 4 & 1 & 1 & 4 & 2 & 17 & 11 & 1 & 11 & 11 & 101 & 2 & 4 & 15 & & \begin{tabular}{l|l}
4 & \\
\end{tabular} & 9 & 1 & 3 & 1 & 14 & 23 & 206 \\
\hline
\end{tabular}


Table V-3. Artifacts from the East Wall Area, Blocks V, VI, and VII

\begin{tabular}{|c|c|c|c|c|c|c|c|c|c|c|c|c|c|c|c|c|c|c|c|c|c|c|c|c|c|c|c|c|c|c|c|c|c|c|c|c|c|c|c|c|c|c|c|c|}
\hline \multirow{2}{*}{\multicolumn{2}{|c|}{ Type }} & \multicolumn{43}{|c|}{ Unit-Level } \\
\hline & & $\vec{a}$ & สิ & $\hat{\alpha}$ & Jू & $\alpha$ & Lั & 굼 & $\alpha$ & $\begin{array}{l}\overrightarrow{4} \\
2\end{array}$ & $\begin{array}{l}\infty \\
2 \\
2\end{array}$ & 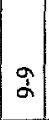 & $\begin{array}{l}0 \\
d \\
\alpha\end{array}$ & $\vec{s}$ & 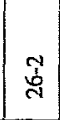 & 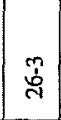 & 总 & 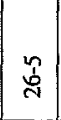 & 号 & 客 & 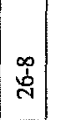 & 离 & 号 & $\overrightarrow{\bar{d}}$ & 宫 & 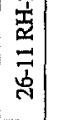 & 告 & 学 & 吉 & 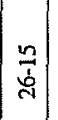 & $\frac{\pi}{N}$ & $\begin{array}{c}N \\
\frac{N}{N}\end{array}$ & $\frac{m}{n}$ & $\frac{t}{\pi}$ & $\frac{n}{N}$ & $\begin{array}{l}0 \\
\frac{1}{v}\end{array}$ & 公 & 号 & $\frac{9}{i}$ & $\frac{9}{1}$ & $\frac{\overrightarrow{7}}{\mathrm{~N}}$ & $\frac{7}{3}$ & $\frac{2}{5}$ & $\underset{N}{\stackrel{m}{S}}$ \\
\hline \multirow{11}{*}{ 鸷 } & Mission Ceramics & 21 & 1 & 4 & & 16 & 39 & 5 & 1 & & & 11 & & 12 & 13 & 2 & 4 & 8 & 2 & 5 & 5 & 73 & \begin{tabular}{|l|l}
66 & 1 \\
\end{tabular} & 124 & 12 & 3 & & 23 & 38 & 54 & 8 & 5 & & 4 & 3 & 2 & 2 & 10 & 79 & 418 & 48 & 14 & & 84 \\
\hline & Edge decorated & & & & & & & & & & & & & & & & & & & & & & & & & & & & & & & & & & & & & & & & & & & \\
\hline & Transfer Printed & & & & & & & & & & & & & & & & & & & & & & & & & & & & & & & & & & & & & & & & & & & \\
\hline & Hand Painted & & & & & & & & & & & & & & & & & & & & & & & & & & & & & & 1 & & & & & & & & & & & & & \\
\hline & Banded Slip & & & & & & & & & & & & & & & & & & & & & & & & & & & & & & & & & & & & & & & & & & & \\
\hline & \begin{tabular}{|l} 
Other \\
\end{tabular} & & & & & & & & & & & & & & 3 & & & 2 & & & & & & & & & & & & & & & & 7 & & & & & & & & & & \\
\hline & Undec. Whiteware & & & & & & & & & & & & & & & & & $\dot{.}$ & & & & & & & & & & & & & & & & & & & & & & & & & & \\
\hline & Porcelain & & & & & & & & & & & & & & & 1 & & & & & 1 & & & & & & & & & & & & & & & & & & & & & & & \\
\hline & Stoneware & & & & & & & & & 1 & & & & & 1 & & & & & & - & & & & & & & & & & & 1 & & & & & & & & & & & & \\
\hline & Plain-colored & 3 & & & & & & & & & & & & & & & & & & & & & & & & & & & & & & & & & & & & & & & & & & \\
\hline & Misc. & & & & & & & & & & & & & & & & & & & & & & & & & & & & & & 1 & 2 & & & & 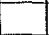 & & & & & & & & \\
\hline \multirow{11}{*}{ 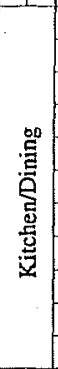 } & Formed Glass (ct.) & 6 & & & 1 & & & & & 3 & & & & 4 & 3 & & & & & & 1 & & & & & & & & & & 13 & 3 & & & & & & & & & & & & \\
\hline & Formed Glass (wt.) & 7 & & & 2 & & & & & 1 & & & & 8 & 2 & & & & & & 5 & & & & & & & & & & & & & & & & 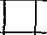 & & & & & & & \\
\hline & Capts, Tops, etc. & & & & & & & & & & & & & & & & & & & & & & & & & & & & & & & & & & & & & & & & & & & \\
\hline & Tin Can Scrap & 26 & & & & & & & & & & & & & & & & & & & & & & & & & & & & & & & & & & & & & & & & & & \\
\hline & Iron Scrap & & & & & & & & & 1 & & & & & 4 & 2 & & & & & & & & & & & & & & & 4 & 6 & & 3 & 1 & & & & & & & & & \\
\hline & Identifiable Objects & 3 & & 1 & & & & & & & & & & & & & & & & & & & & & & 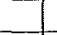 & & & & & & & & & & & & & & & & & & \\
\hline & \begin{tabular}{|l|} 
Other Metal \\
\end{tabular} & & & & & & & & & & & & & & & & & & & & & & & & 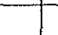 & 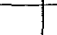 & & & & & & & 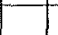 & 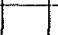 & 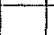 & 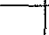 & 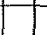 & 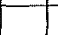 & 1 & & 1 & & & \\
\hline & \begin{tabular}{|l|} 
Tableware \\
\end{tabular} & & & & & & & & & & & & & & & & & & & & & & & & & & & & - & & & & & & & 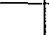 & & & & & & & & \\
\hline & Kitchenware & & & & & & & & & & & & & & & & & & & & & & & & & & & & & & & & & & & & & & & & & & & \\
\hline & Bone (wt.) & 178 & 856 & 84 & 248 & 68 & 220 & 5 & 12 & 10 & 2 & 11 & 93 & 78 & 935 & 143 & 83 & 916 & 137 & 528 & \begin{tabular}{l|l}
2808 \\
\end{tabular} & 8617 & 7499 & \begin{tabular}{l|l}
930 & 5
\end{tabular} & 58 & 17 & $57 \sqrt{3}$ & \begin{tabular}{l|l}
383 & 3 \\
\end{tabular} & \begin{tabular}{|l|l|}
3802 \\
\end{tabular} & 223 & 199 & 81 & 20 & 149 & 13 & 11 & 4 & 80 & 2447 & 2849 & 387 & 515 & & 223 \\
\hline & Mussell Shell & 1 & 1 & 2 & & & 1 & & & & & & & & 4 & & 2 & & & & 2 & 5 & 7 & 3 & & & & 1 & & & 2 & 2 & 1 & 1 & & & & & 8 & 4 & & & & 1 \\
\hline \multirow{3}{*}{ 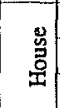 } & Furniture Hardware & & & & & & & & & & & & & & & & & & & & & & & & & & & & & & & & & & & & & & & & & & & \\
\hline & Chimney Glass & & & & & & & & & & & & & & & & & & & & & & & & & & & & & & & & & & & & & & & & 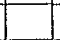 & & & \\
\hline & Lightbulb Glass & & & & & & & & & & & & & & & & & & & & & & & & & & & & & & & & & & & & & & & & & & & \\
\hline \multirow{5}{*}{$\begin{array}{l}\text { 足 } \\
\text { 咅 } \\
0\end{array}$} & Buttons & 10 & & & & 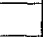 & & & & 1 & & & & 1 & & & & & & & & & & & & & & & & & & 1 & & & & & & & & & & & & \\
\hline & Hooks, Snaps, etc. & & & & & & & & & & & & & & & & & & & & & & & & & & & & & & & & & & & & & & & & 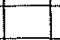 & & & \\
\hline & Buckles & 2 & & & & & & & & & & & & & & & & & & & & & & & & & & & & & & & & & & & & & & & 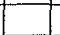 & & & \\
\hline & Sewing Items & & & & & & & & & & & & & & & & & & & & & & & & & & & & & & & $\cdot$ & & & & & & & & & - & & & \\
\hline & Misc. & & & & & & & & & & & & & & & & & & & & & & & & & & & & & & & & & & & & & & & & & & & \\
\hline \multirow{3}{*}{ 它 } & Beads & & & 1 & & 1 & & & & & & & & & & & & & & & & & & & & & & & & & & 1 & & & & & & & 3 & & 1 & & & \\
\hline & Pipes & & & & & & & & & & & & & & & & & & & & & & & & & & & & & & & & & & & & & & & & & & & \\
\hline & Misc. & 2 & & & & & & & & & & & & & & & & & & & & & & & & & & & & & & & & & & & & & & & & & & \\
\hline \multirow{3}{*}{$\ddot{q}$} & Toys & & & & & & & & & & & & & & & & & & & & & & & & & & & & & & & & & & & & & & & 1 & & & & \\
\hline & Writing Material & & & & & & & & & & & & & & & & & & & & & & & & & & & & & & & & & & & & & & & & & & & \\
\hline & Misc. & & & & & & & & & & & & & & & & & & & & & & & & & & & & & & & & & & & & & & & & & & & \\
\hline
\end{tabular}


Table V-3. continued

Unit-Level

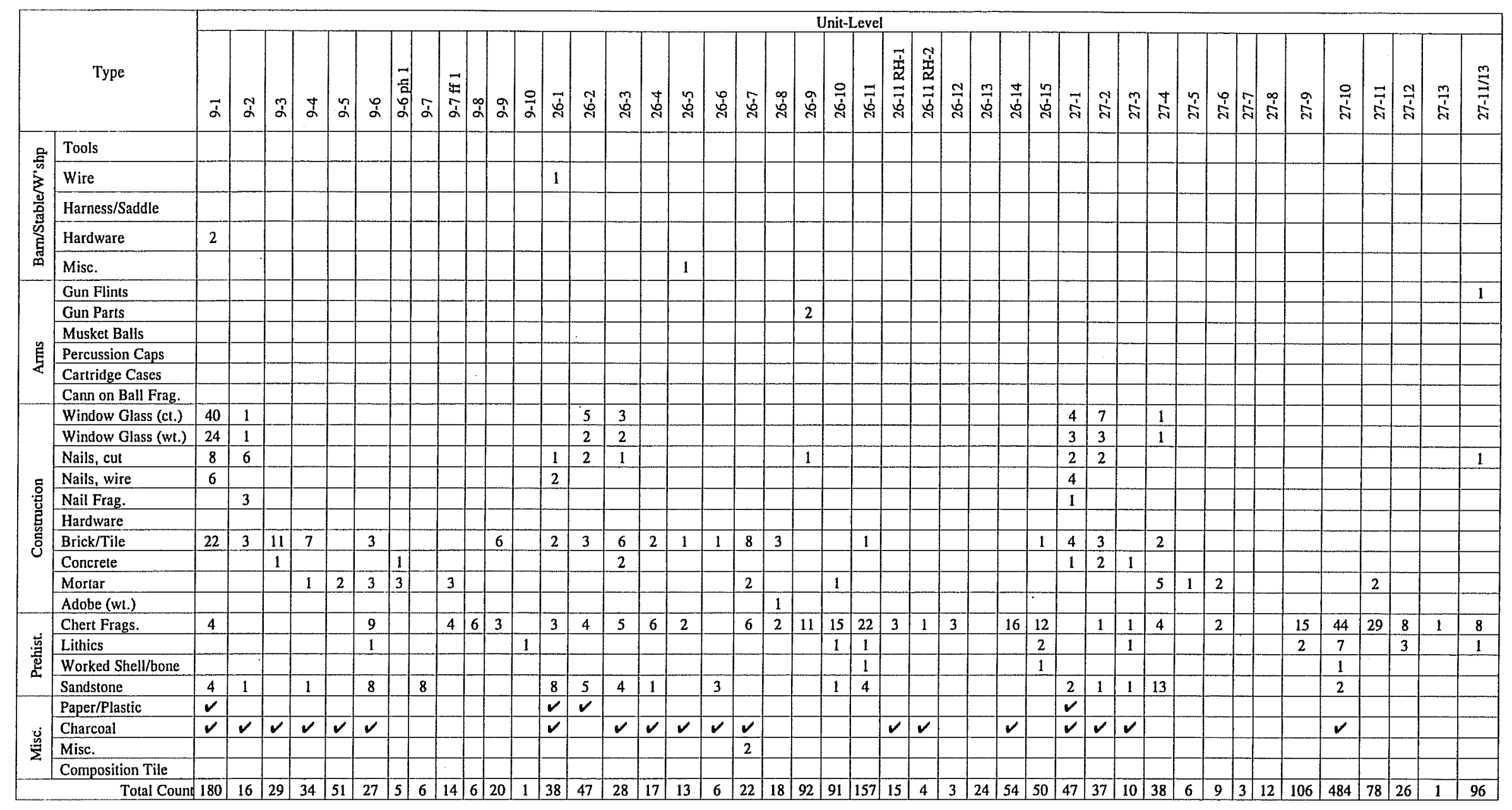


Table V-3. continued

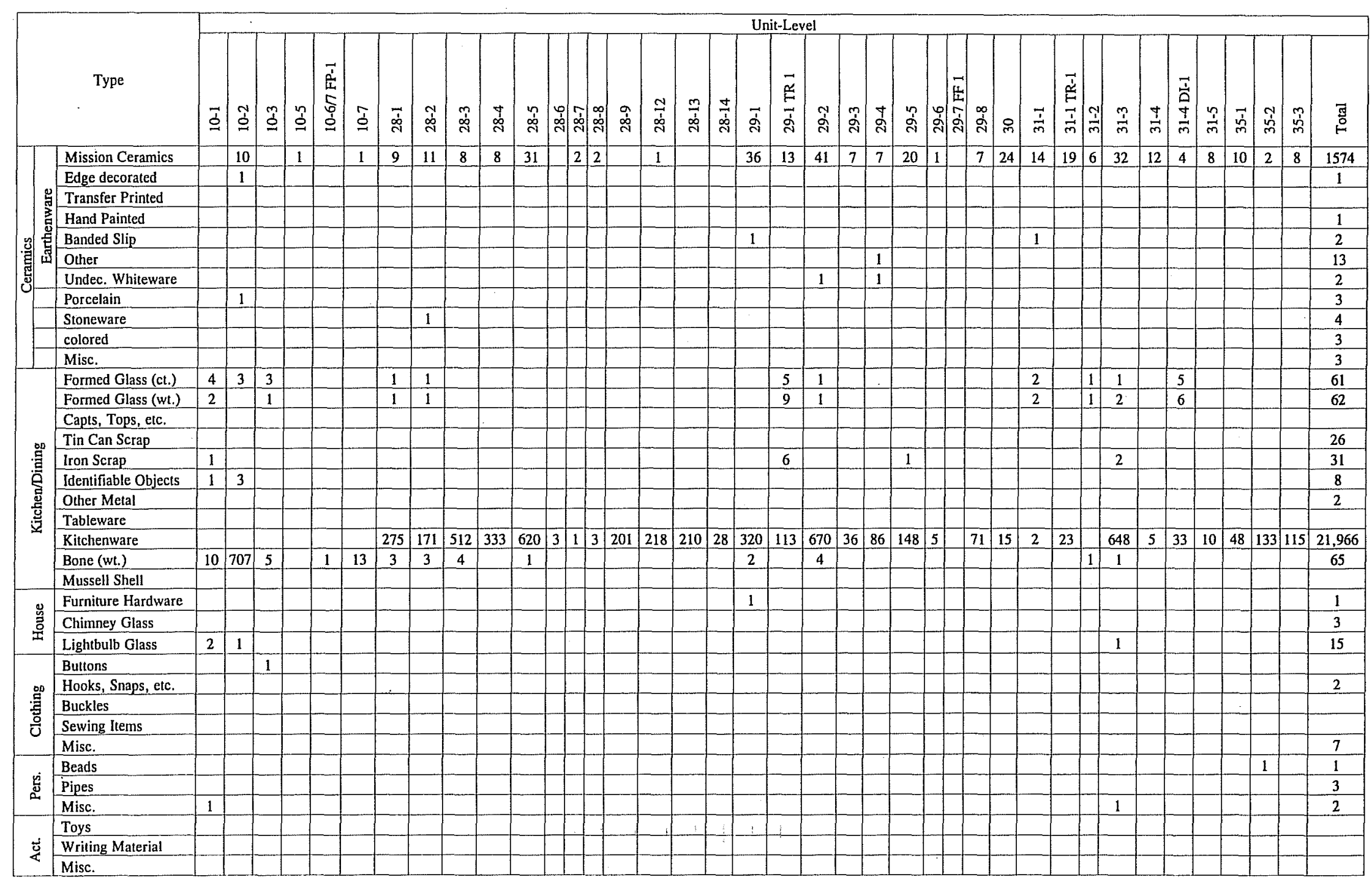


Table V-3. continued

\begin{tabular}{|c|c|c|c|c|c|c|c|c|c|c|c|c|c|c|c|c|c|c|c|c|c|c|c|c|c|c|c|c|c|c|c|c|c|c|c|c|c|c|c|}
\hline \multirow{2}{*}{\multicolumn{2}{|c|}{ Type }} & \multicolumn{38}{|c|}{ Unit-Level } \\
\hline & & $\overrightarrow{0}$ & 气̃ & 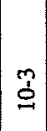 & 旾 & 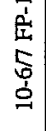 & g̊ & $\vec{d}$ & ণ్ & 疋 & 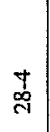 & 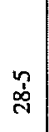 & 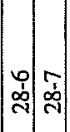 & 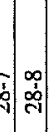 & 总 & 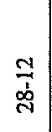 & 獣 & 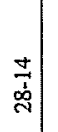 & $\overrightarrow{\mathrm{d}}$ & $\begin{array}{l}\vec{a} \\
\stackrel{a}{*} \\
\dot{a}\end{array}$ & $\begin{array}{l}\text { ते } \\
\text { 'े }\end{array}$ & în & ปั & ñ & مิ & 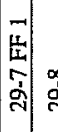 & 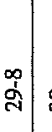 & 을 & $\vec{I}$ & $\begin{array}{l}\vec{s} \\
\stackrel{s}{E} \\
\vec{m}\end{array}$ & $\frac{1}{m}$ & $\frac{m}{m}$ & $\frac{ \pm}{m}$ & $\begin{array}{l}\overrightarrow{\vec{d}} \\
\vec{\Delta} \\
\vec{n}\end{array}$ & $\frac{n}{m}$ & 鬲 & 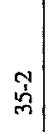 & 离 & 惒 \\
\hline \multirow{5}{*}{ 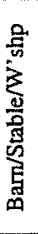 } & Tools & & & & & & & & & & & & & & & & & & & & & & & & & & & & & & & & & & & & & & \\
\hline & Wire & & & & & & & & & & & & & & & & & & & & & & & & & & & & & & & & & & & & & & 1 \\
\hline & Harness/Saddle & & & & & & & & & & & & & & & & & & 2 & 1 & & & & & & & & & & & & & & & & & & & \\
\hline & Hardware & & & & & & & & & & 2 & & & & & & & & 2 & 1 & & & & & & & & & & & & & & & & & & & 7 \\
\hline & Misc. & & & & & & & & & & & & & & & & & & & & & & & & & & & & & & & & & & & & & & 1 \\
\hline \multirow{6}{*}{ 宸 } & Gun Flints & & & & & & & & & & & & & & & & & & & & & & & & & & & & & & & & & & & & & & 1 \\
\hline & Gun Parts & & & & & & & & & & & & & & & & & & & & & & & & & & & & & & & & & & & & & & 2 \\
\hline & Musket Balls & & & & & & & & & & & & & & & & & & & & & & & & & & & & & & & & & & & & & & \\
\hline & Percussion Caps & & & & & & & & & & & & & & & & & & & & & & & & & & & & & & & & & & & & & & \\
\hline & Cartridge Cases & & & & & & & & & & & & & & & & & & & & & & & & & & & & & & & & & & & & & & 1 \\
\hline & Cann on Ball Frag. & & 1 & & & & & & & & & & & & & & & & & 1 & & & & & & & & & & & & & & & & & & & 1 \\
\hline \multirow{11}{*}{ 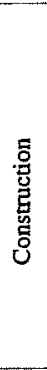 } & Window Glass (ct.) & & 1 & & & & & 1 & 2 & & & & & & & & & & 11 & 1 & 2 & & & & & & & & & & & & & & & & & & 79 \\
\hline & Window Glass (wt.) & & 1 & & & & & 1 & 1 & & & & & & & & & & 8 & 2 & 2 & & & & & & & & & & & & & & & & & & 51 \\
\hline & Nails, cut & 1 & 3 & & & & & 1 & & & & 1 & & & & & & & 4 & 1 & & & & & & & & & & & & & & & & & & & 35 \\
\hline & Nails, wire & & & & & & & 5 & & & & & & & & & & & & & & & & & & & & & & & & & & & & & & & 17 \\
\hline & Nail Frag. & & & & & & 1 & & & & & & & & & & & & 4 & & 1 & & & & & & & & & & & & & & & & & & 10 \\
\hline & Hardware & & & & & & & & & & & & & & & & & & & & & & & & & & & & & & & & & & 1 & & & & 1 \\
\hline & Brick/Tile & 11 & 12 & & & & 2 & 7 & 4 & 2 & 2 & & & & & & & & 75 & 5 & 1 & 5 & & 2 & & & & 2 & 1 & 3 & & 8 & & 4 & & & 13 & 2 & 248 \\
\hline & Concrete & 1 & & & & & & & 5 & 1 & & & & & & & & & & 1 & & & & & & & & & & & & & & & & & & & 10 \\
\hline & Mortar & & & & & & & & & & & & & & & & & & & & & & & & & 1 & & & & & & & & & & & 4 & 4 & 39 \\
\hline & Mortar w/whiteawsh & & & & & & & & & 4 & 3 & & & & & & & & 6 & 6 & 11 & 1 & & & & & & 1 & & 1 & & 2 & & & & & 18 & & 73 \\
\hline & Adobe (wt.) & 3 & 4 & 1 & & & & & & & & & & & & & & & & & & & & & & & & & & & 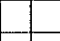 & & & & & & 1 & & 2 \\
\hline \multirow{4}{*}{ 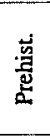 } & Chert Frags. & & & & & & & & & & 2 & 3 & & 1 & 7 & 1 & & & 11 & 3 & 3 & 2 & 6 & 9 & & & & 4 & 1 & \begin{tabular}{l|l}
4 \\
\end{tabular} & 1 & & 10 & 2 & 2 & 1 & 8 & & .365 \\
\hline & Lithics & & & & & & & & & & & 1 & & & & 3 & & & & & 1 & & & 2 & & & & 1 & 1 & 1 & & & & & & & & & 30 \\
\hline & Worked Shell/bone & & 10 & & & & & & 1. & & & & & & & & & & & & & & & 2 & & & & & & & & & & & & & & & 6 \\
\hline & Sandstone & $\checkmark$ & & & & & & 1 & 7 & 2 & & & & 2 & & & & & 9 & 1 & 4 & 1 & & & & & & & & 1 & & & 2 & & & & 1 & & 103 \\
\hline \multirow{4}{*}{ 离 } & Paper/Plastic & & & & & & & $\checkmark$ & $v$ & & & & & & & & & & & & & & & & & & & & & & & & & & $v$ & & & & \\
\hline & Charcoal & & & & & & & $\checkmark$ & $\checkmark$ & $\checkmark$ & $v$ & & & & & $\checkmark$ & & & $\checkmark$ & $\checkmark$ & $r$ & & & & & & & $\checkmark$ & & & 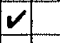 & & & & & $\checkmark$ & & & \\
\hline & Misc. & & & & & & & & & & & & & & & & & & & & & & & & & & & & & & & & & & & & & $\ldots$ & 3 \\
\hline & Composition Tile & 25 & 52 & 5 & 1 & & 4 & & & & & & & & & & & & & & & & & & & & & & & & & & & & & & & & \\
\hline & Total Count Table V-3 & & & & & & & 32. & 31 & 23 & 15 & 37 & 2 & 5 & 7 & 5 & & & 175 & 33 & 69 & 16 & 1413 & 36 & \begin{tabular}{|l|l|}
1 & \\
\end{tabular} & \begin{tabular}{|l|l|}
1 & 12 \\
\end{tabular} & $12 \sqrt{2}$ & 29 & 24 & 24 & 8 & 80 & 14 & 15 & 9 & 11 & 48 & 14 & 2880 \\
\hline
\end{tabular}


Table V-4. Ceramics from East Wall Area, Blocks V, VI, and VII

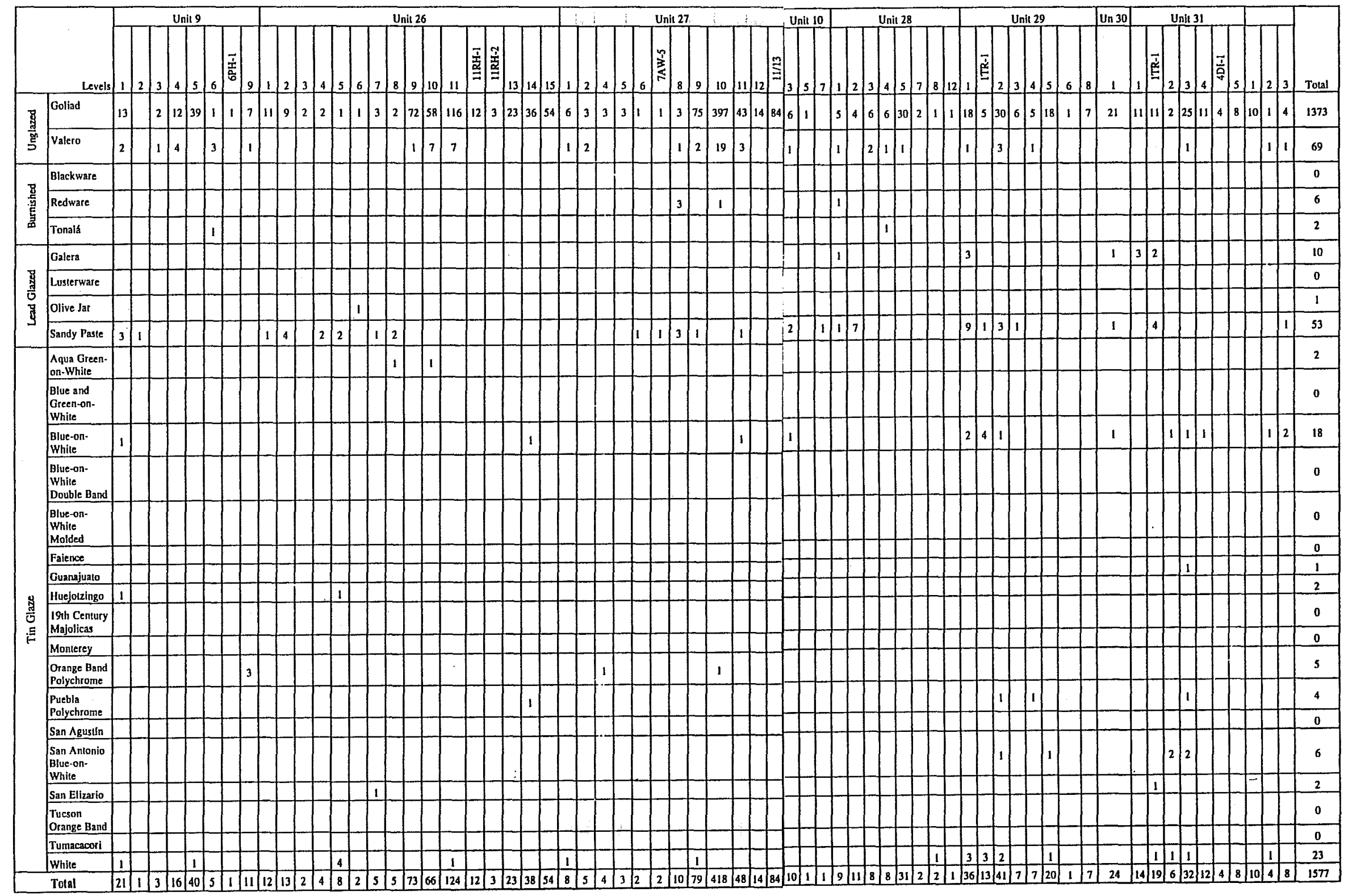


Table V-5. Artifacts from Northwest Corner Area, Blocks VIII and IX

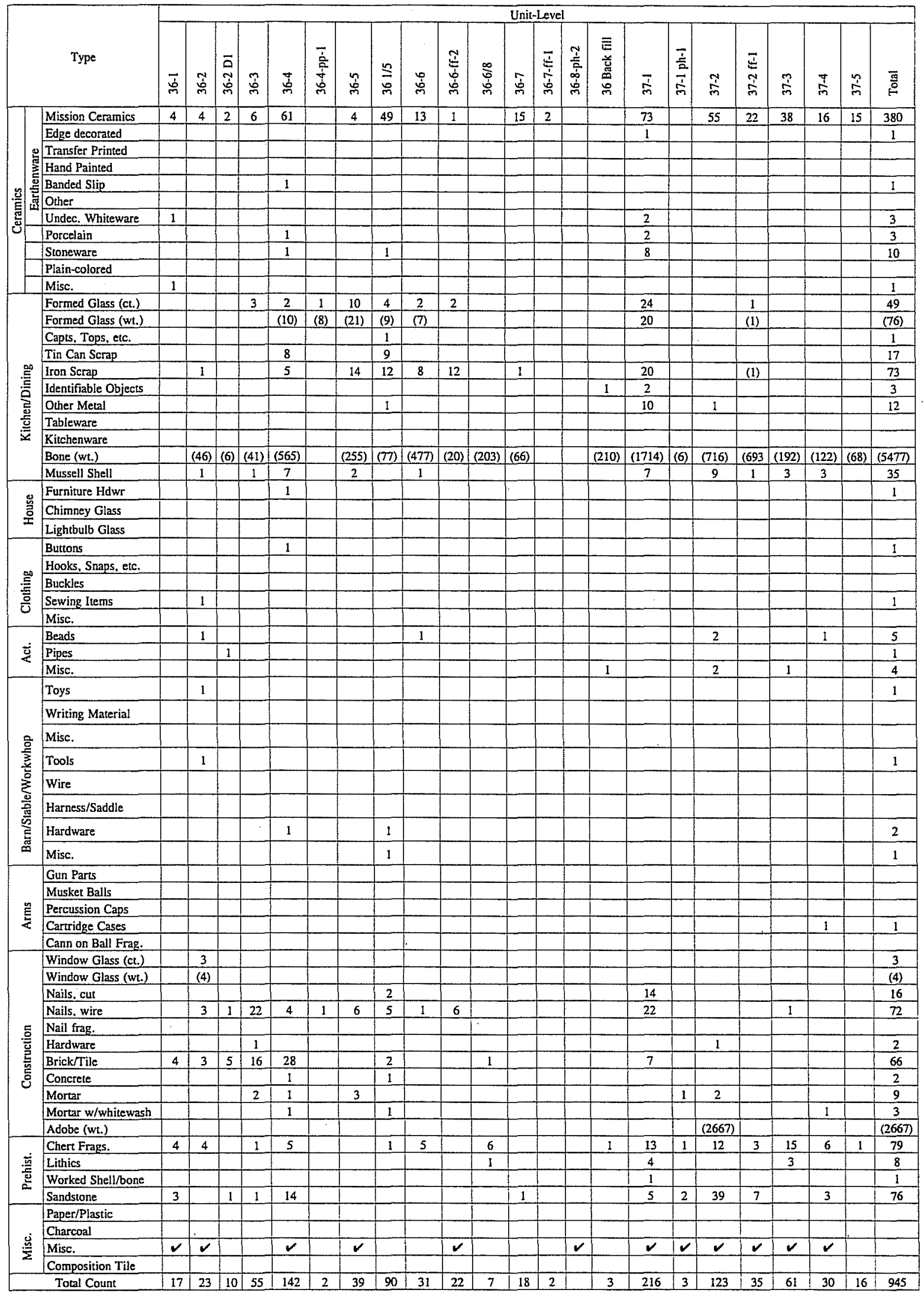


Table V-6. Ceramics from Northeast Corner Area, Blocks VIII and IX

\begin{tabular}{|c|c|c|c|c|c|c|c|c|c|c|c|c|c|c|c|c|c|c|c|}
\hline \multirow{2}{*}{\multicolumn{2}{|c|}{ Levels }} & \multicolumn{11}{|c|}{ Unit 36} & \multicolumn{6}{|c|}{ Unit 37} & \multirow[b]{2}{*}{ Total } \\
\hline & & 1 & 2 & 2-D1 & 3 & 4 & 5 & $1 / 5$ & 6 & $6 \mathrm{FF}-2$ & 7 & 7FF-1 & 1 & 2 & 2FF-1 & 3 & 4 & 5 & \\
\hline \multirow{2}{*}{ 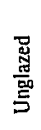 } & Goliad & 2 & 1 & 1 & & 21 & 8 & 19 & 6 & & & 2 & 31 & 22 & 5 & 37 & 5 & 9 & 176 \\
\hline & Valero & & 1 & & & 7 & 1 & 4 & 2 & & & & 3 & 1 & & & & & 19 \\
\hline \multirow{3}{*}{ 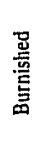 } & Blackware & & & & & & & 1 & & & & & & & & & & & 1 \\
\hline & Redware & & & & & & & & & & & & & 1 & & & & & 1 \\
\hline & Tonalá & & & & & & & & & & & & & & & & & & 0 \\
\hline \multirow{4}{*}{ 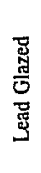 } & Galera & & & & & 2 & & 2 & & & & & 1 & 5 & 1 & & 3 & 1 & 15 \\
\hline & Lusterware & & & & & 3 & & & & & & & & & & & & & 3 \\
\hline & Olive Jar & & & & & & & & & & & & & & & & & & 0 \\
\hline & Sandy Paste & 2 & 1 & & 1 & 19 & & 12 & 4 & & 5 & & 17 & 20 & 12 & 1 & 6 & 2 & 102 \\
\hline \multirow{19}{*}{ 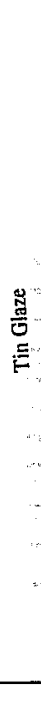 } & Aqua Green-on-White & & & & & & & & & & & & & & & & & & 0 \\
\hline & Blue and Green-on-White & & & & & & & & & & & & & & & & & & 0 \\
\hline & Blue-on-White & & 1 & & 2 & 1 & 1 & 2 & & & 2 & & 7 & 2 & 3 & & 1 & & 22 \\
\hline & Blue-on-White Double & & & & & & & & & & & & & & & & & & 0 \\
\hline & Blue-on-White Molded & & & & & & & & & & & & 1 & & & & & & 1 \\
\hline & Faience & & & & & & & & & & & & & & & & 1 & & 1 \\
\hline & Guanajuato & & & & & & & & & & & & & & & & . & & 0 \\
\hline & Huejotzingo & & & & & 1 & & 1 & & & & & & & 1 & & 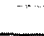 & & 3 \\
\hline & 19th Century Majolicas & & & & & & & & & & & & & & & & $\ldots . .$. & & 0 \\
\hline & Monterey & & & & 3 & & & & & & & & & & & & 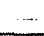 & & 3 \\
\hline & Orange Band & & & & & & & 1 & & & & & & 1 & & & $\cdots$ & & 2 \\
\hline & Puebla Polychrome & & & & & & & & & & & & & & & & & & 0 \\
\hline & San Agustín & & & & & & 1 & & & & & & & & & & - & & 1 \\
\hline & San Antonio Blue-on- & & & & & & & & & & & & & & & & $\ldots$ & & 0 \\
\hline & San Elizario & & & & & & & 1 & & & 1 & & 4 & & & & $\ldots$ & & 6 \\
\hline & Tucson Orange Band & & & & & & & & & & & & 1 & & & & .. & & 1 \\
\hline & Tumacacori & & & & & & & & & & & & & & & & & & 0 \\
\hline & White & & & & & 6 & 2 & 6 & 1 & 1 & & & 8 & 3 & & & & 3 & 30 \\
\hline & Total & 4 & 4 & 1 & 6 & 61 & 12 & 49 & 13 & 1 & 15 & 2 & 73 & 55 & 22 & 38 & 16 & 15 & 387 \\
\hline
\end{tabular}


Table V-7. Artifacts from West Wall Area, Block XI

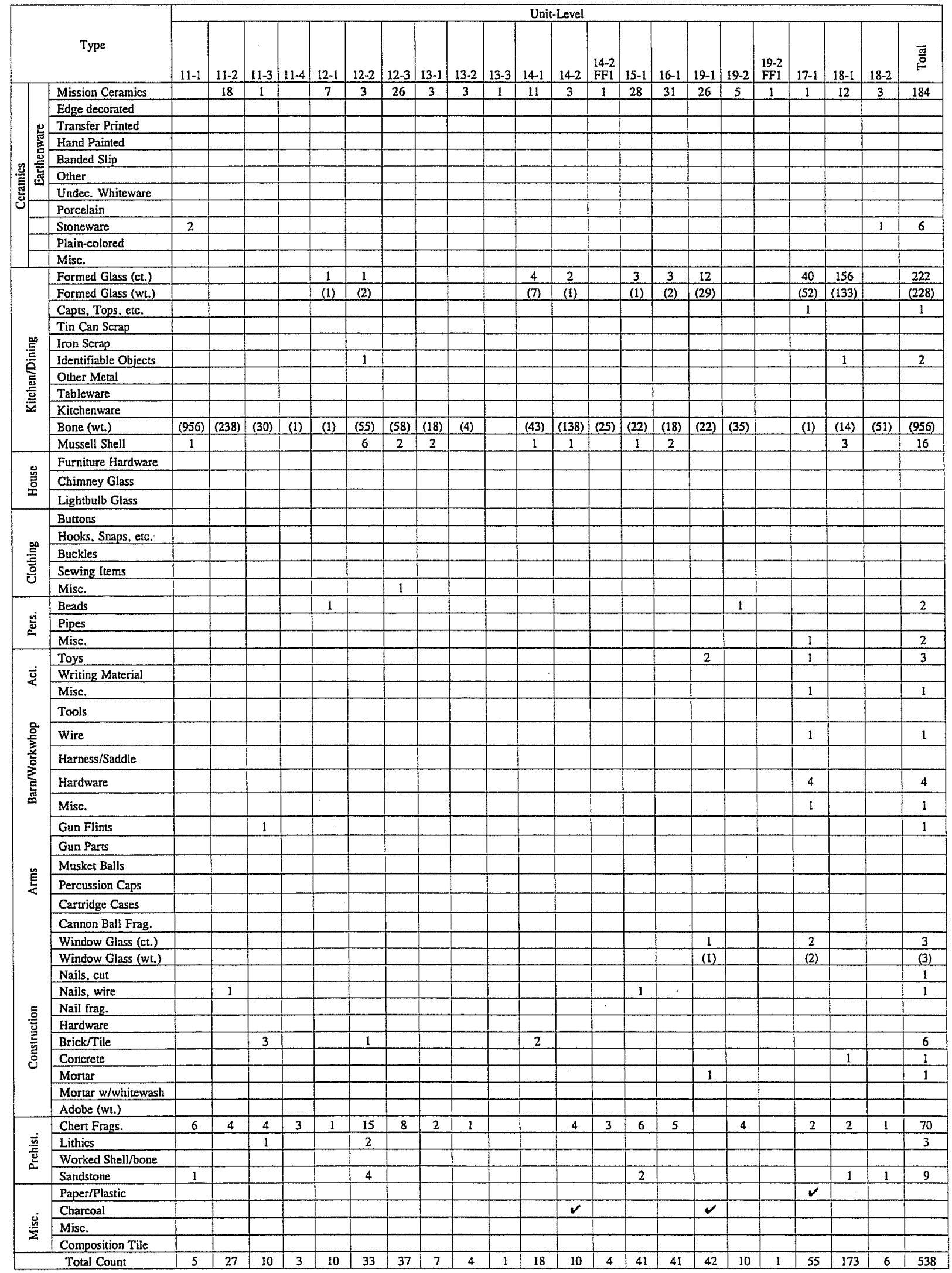


Table V-8. Ceramics from West Wall Area, Block XI

\begin{tabular}{|c|c|c|c|c|c|c|c|c|c|c|c|c|c|c|c|c|c|c|c|c|c|}
\hline \multirow{2}{*}{\multicolumn{2}{|c|}{ Levels }} & \multicolumn{2}{|c|}{ Unit 11} & \multicolumn{3}{|c|}{ Unit 12} & \multicolumn{3}{|c|}{ Unit 13} & \multicolumn{3}{|c|}{ Unit 14} & \multirow{2}{*}{\begin{tabular}{|c|} 
Unit 15 \\
1 \\
\end{tabular}} & \multirow{2}{*}{\begin{tabular}{|c|} 
Unit 16 \\
1 \\
\end{tabular}} & \multicolumn{3}{|c|}{ Unit 19} & \multirow{2}{*}{\begin{tabular}{|c|} 
Unit 17 \\
1
\end{tabular}} & \multicolumn{2}{|c|}{ Unit 18} & \multirow[b]{2}{*}{ Total } \\
\hline & & 2 & 3 & 1 & 2 & 3 & 1 & 2 & 3 & 1 & 2 & $2 \mathrm{FF}-2$ & & & 1 & 2 & $2 \mathrm{FF}-1$ & & 1 & 2 & \\
\hline \multirow{2}{*}{$\begin{array}{l}\text { : } \\
\text { 总 } \\
\text { E } \\
\text { E }\end{array}$} & Goliad & 16 & & 7 & 3 & 26 & 2 & 3 & 1 & 9 & 2 & 1 & 25 & 28 & 22 & 3 & & 1 & 7 & 1 & 157 \\
\hline & Valero & & & & & & 1 & & & & & & & & & & & & & & 1 \\
\hline \multirow{3}{*}{ 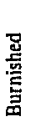 } & Blackware & & & & & & & & & & & & & & & & & & & & 0 \\
\hline & Redware & & & & & & & & & & & & & & & & & & & & 0 \\
\hline & Tonalá & & & & & & & & & & & & & & & & & & & & 0 \\
\hline \multirow{4}{*}{ 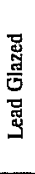 } & Galera & & & & & & & & & & & & & & & & & & & & 0 \\
\hline & Lusterware & & & & & & & & & & & & & & & & & & & & 0 \\
\hline & Olive Jar & & & & & & & & & & & & & & & & & & & 1 & 1 \\
\hline & Sandy Paste & & 1 & & & & & & & 1 & 1 & & 1 & & 2 & 1 & & & 1 & & 8 \\
\hline \multirow{18}{*}{ 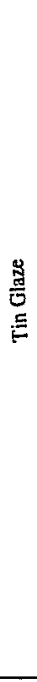 } & Aqua Green-on-White & & & & & & & & & & & & & & & & & & & & 0 \\
\hline & Blue and Green-on-White & & & & & & & & & & & & & & & & & & & & 0 \\
\hline & Blue-on-White & & & & & & & & & 1 & & & 1 & 1 & 1 & 1 & 1 & & 3 & 1 & 10 \\
\hline & Blue-on-White Double & & & & & & . & & & & & & & & & & & & & & 0 \\
\hline & Blue-on-White Molded & & & & & & & & & & & & & & & & & & & & 0 \\
\hline & Faience & & & & & & & & & & & & & & & & & & & & 0 \\
\hline & Guanajuato & & & & & & & & & & & & & & & & & & & & 0 \\
\hline & Huejotzingo & & & & & & & & & & & & & & & & & & & & 0 \\
\hline & 19th Century Majolicas & & & & & & & & & & & & & & & & & & & & 0 \\
\hline & Monterey & & & & & & & & & & & & & & & & & & & & 0 \\
\hline & Orange Band & & & & & & & & & & & & & & & & & & & & 0 \\
\hline & Puebla Polychrome & & & & & & & & & & & & & & & & & & & & 0 \\
\hline & San Agustin & & & & & & & & & & & & & & & & & & & & 0 \\
\hline & San Antonio Blue-on- & & & & & & & & & & & & & & & & & & & & 0 \\
\hline & San Elizario & & & & & & & & & & & & & & & & & & 1 & & 1 \\
\hline & Tucson Orange Band & & & & & & & & & & & & & & & & & & & & 0 \\
\hline & Tumacacori & & & & & & & & & & & & & & & & & & & & 0 \\
\hline & White & 2 & & & & & & & & & & & 1 & 2 & 1 & & & & & & 6 \\
\hline & Total & 18 & 1 & 7 & 3 & 26 & 3 & 3 & 1 & 11 & 3 & 1 & 28 & 31 & 26 & 5 & 1 & 1 & 12 & 3 & 184 \\
\hline
\end{tabular}


Table V-9. Artifacts from South Wall Area, Block XII

\begin{tabular}{|c|c|c|c|c|c|c|c|c|c|c|c|c|}
\hline \multirow{2}{*}{\multicolumn{2}{|c|}{ Type }} & \multicolumn{11}{|c|}{ Unit-Level } \\
\hline & & $42-2$ & $43-1$ & $44-1$ & $46-2$ & $47-1$ & 49-1-FF & 49-8-FF & $45-1$ & $45-2$ & $48-1$ & Total \\
\hline \multirow{9}{*}{ : } & Mission Ceramics & 246 & & 2 & 3 & 13 & 15 & 1 & 102 & 25 & 16 & 423 \\
\hline & Edge decorated & & & & & & & & & 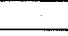 & & \\
\hline & Hand Painted & & & & & & & & & & & \\
\hline & Banded Slip & & & & & & & & & & & \\
\hline & Other & & & & & & & & & & & \\
\hline & Undec. Whiteware & & & & & & 138 & 1 & & & & 139 \\
\hline & Stoneware & & & & & & 4 & & & & & 4 \\
\hline & Plain-colored & & & & & & & & & & & \\
\hline & Misc. & & & & & & 1 & 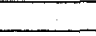 & & & & 1 \\
\hline \multirow{10}{*}{ 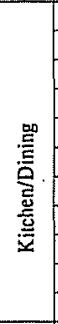 } & Formed Glass (ct.) & & & & & 2 & 45 & 2 & 2 & 3 & & 54 \\
\hline & Formed Glass (wt.) & & & & & 3 & 259 & 8 & 2 & 2 & & 274 \\
\hline & Capts, Tops, etc. & & & & & & 3 & 1 & & & & 4 \\
\hline & Tin Can Scrap & & & & , & & 4 & & & & & 4 \\
\hline & Iron Scrap & & & & & & 69 & & & & 3 & 72 \\
\hline & Other Metal & & & & & & 4 & 3 & & & & 7 \\
\hline & Tableware & & & & & & & & & & & \\
\hline & Kitchenware & & & & & & & & & & & \\
\hline & Bone (wt.) & 406 & 258 & 148 & 11 & 83 & 1459 & 45 & 5967 & 2356 & 243 & 10,706 \\
\hline & Mussell Shell & 16 & & & & 1 & 2 & & 1 & 1 & 1 & 22 \\
\hline \multirow{3}{*}{$\begin{array}{l}\text { 岁 } \\
\text { 空 }\end{array}$} & Furniture Hardware & & & & & & & & & & & \\
\hline & Chimney Glass & & & & & & 1 & & & & & 1 \\
\hline & Lightbulb Glass & & & & & & & & & & & \\
\hline \multirow{5}{*}{ 哭 } & Buttons & & & & & & 1 & & & & & 1 \\
\hline & Hooks, Snaps, etc. & & & & & & & & & & & \\
\hline & Buckles & & & & & & & & & & & \\
\hline & Sewing Items & & & & & & & & & & & \\
\hline & Misc. & & & & & & & & & & & \\
\hline \multirow{3}{*}{ 离 } & Beads & 2 & & 1 & & & & & & 1 & & 4 \\
\hline & Pipes & & & & & & & & & & & \\
\hline & Misc. & & & & & & 1 & & & & & 1 \\
\hline ن் & Tools & & & & & & & & & & & \\
\hline 产 & Wire & & & & & & 54 & & & & & 54 \\
\hline$\stackrel{\text { L }}{\stackrel{5}{2}}$ & Harness/Saddle & & & & & & 1 & & 1 & & & 2 \\
\hline 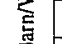 & Harware & & & & & & 2 & & & & & 2 \\
\hline & Misc. & & & & & & 5 & & & & & 5 \\
\hline & Gun Flints & & & & & & & & & & & \\
\hline & Gun Parts & & & & & & & & & & & \\
\hline & Musket Balls & & & & & & & & & & & \\
\hline$\underline{E}$ & Percussion Caps & & & & & & & & & & & $\cdot$ \\
\hline & Cartridge Cases & & & & & & 2 & & & & & 2 \\
\hline & Cann on Ball Frag. & & & & & & & & & & & \\
\hline & Window Glass (ct.) & & & & & & 6 & & & & & 6 \\
\hline & Window Glass (wt.) & & & & & & 12 & & & & & 12 \\
\hline & Nails, cut & & & & & & 14 & 2 & & 1 & & 17 \\
\hline & Nails, wire & & & & & & 7 & 1 & & & & 8 \\
\hline 5 & Nail Frag. & & & & & & & 1 & & & & 1 \\
\hline 气 & Hardware & & & & & & & & & & & \\
\hline$\frac{Z}{2}$ & Brick/Tile & & & & & & 5 & & 12 & & & 17 \\
\hline$\tilde{0}$ & Concrete & & & & & & & & & & & \\
\hline & Mortar & & & & & & & & & 1 & & 1 \\
\hline & Mortar w/whitewash & & & 1 & & & & & & & & 1 \\
\hline & Adobe (wt.) & & & & & & & & & & & \\
\hline & Cher Frags. & 51 & & & & 8 & 2 & & 21 & 5 & 2 & 89 \\
\hline.$\dot{n}$ & Lithics & & & & & & & & & & & 10 \\
\hline 荳 & Worked Shell/bone & & & & & & & & & & & \\
\hline & Sandstone & & & & & & 1 & & 5 & 16 & & 22 \\
\hline & Paper/Plastic & & & & & & & & & & & \\
\hline & Charcoal & & & & & & & & $\checkmark$ & & & \\
\hline$\frac{\mathrm{m}}{z}$ & Misc. & $\checkmark$ & & $\checkmark$ & & & $\checkmark$ & & . & $\therefore$ & & \\
\hline & Composition Tile & & $\checkmark$ & & & & & & & & & \\
\hline & Total Count & & & 4 & 3 & 24 & 390 & 12 & 144 & 56 & 19 & 977 \\
\hline
\end{tabular}


Table V-10. Ceramics from South Wall Area, Block XIII

\begin{tabular}{|c|c|c|c|c|c|c|c|c|c|c|c|}
\hline \multirow{2}{*}{\multicolumn{2}{|c|}{ Levels }} & \multirow{3}{*}{$\frac{\text { Unit } 42}{2}$} & \multirow{3}{*}{$\frac{\text { Unit } 44}{1}$} & \multirow{3}{*}{$\frac{\text { Unit } 46}{1}$} & \multirow{3}{*}{$\begin{array}{c}\text { Unit } 47 \\
1 \\
7\end{array}$} & \multicolumn{2}{|c|}{ Unit 49} & \multicolumn{2}{|c|}{ Unit 45} & \multirow{2}{*}{$\frac{\text { Unit } 48}{1}$} & \multirow[b]{2}{*}{ Total } \\
\hline & & & & & & $1 \mathrm{FF}$ & BD FF & 1 & 2 & & \\
\hline \multirow{2}{*}{ 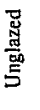 } & Goliad & & & & & 3 & & 61 & 14 & 11 & 332 \\
\hline & Valero & & & & & 3 & 1 & 1 & & 1 & 6 \\
\hline \multirow{3}{*}{ 总 } & Blackware & & & & & & & & & & 0 \\
\hline & Redware & & & & & & & & 1 & & 1 \\
\hline & Tonalá & & & & & & & & & & 0 \\
\hline \multirow{4}{*}{ 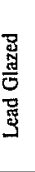 } & Galera & & & 1 & & & & & & & 1 \\
\hline & Lusterware & & & & & & & 1 & & & 1 \\
\hline & Olive Jar & & & & & & & & & & 0 \\
\hline & Sandy Paste & 1 & & & 4 & 4 & & 4 & & 1 & 14 \\
\hline \multirow{18}{*}{ 苞 } & Aqua Green-on-White & & & & & & & & & & 0 \\
\hline & Blue and Green-on-White & & & & & & & & & & 0 \\
\hline & Blue-on-White & 7 & & & 1 & 2 & & 15 & 4 & 2 & 31 \\
\hline & Blue-on-White Double & & & & & & & & & & 0 \\
\hline & Blue-on-White Molded & & & & & & & 1 & 4 & & 5 \\
\hline & Faience & & & & & & & 1 & & & 1 \\
\hline & Guanajuato & & & & & & & 1 & 1 & & 2 \\
\hline & Huejotzingo & 1 & & 1 & 1 & & & 1 & & & 4 \\
\hline & 19th Century Majolicas & & & & & & & 1 & & & 1 \\
\hline & Monterey & & & & & & & & & $\ldots$ & 0 \\
\hline & Orange Band & 1 & & & & & & & & $\cdots$ & 1 \\
\hline & Puebla Polychrome & 1 & & & & & & & & $+x$ & 1 \\
\hline & San Agustin & & & & & & & & & $\ldots$ & 0 \\
\hline & San Antonio Blue-on- & & & & & & & & & $\cdots$ & 0 \\
\hline & San Elizario & & & & & & & 9 & 1 & 1 & 11 \\
\hline & Tucson Orange Band & & & & & & & & & $\cdots$ & 0 \\
\hline & Tumacacori & & & & & & & & & $\cdots$ & 0 \\
\hline & White & 2 & & & & 3 & & 6 & & & 11 \\
\hline & Total & 246 & 2 & 3 & 13 & 15 & 1 & 102 & 25 & 16 & 423 \\
\hline
\end{tabular}


Table V-11. Artifacts from South Gate Area, Block XIII

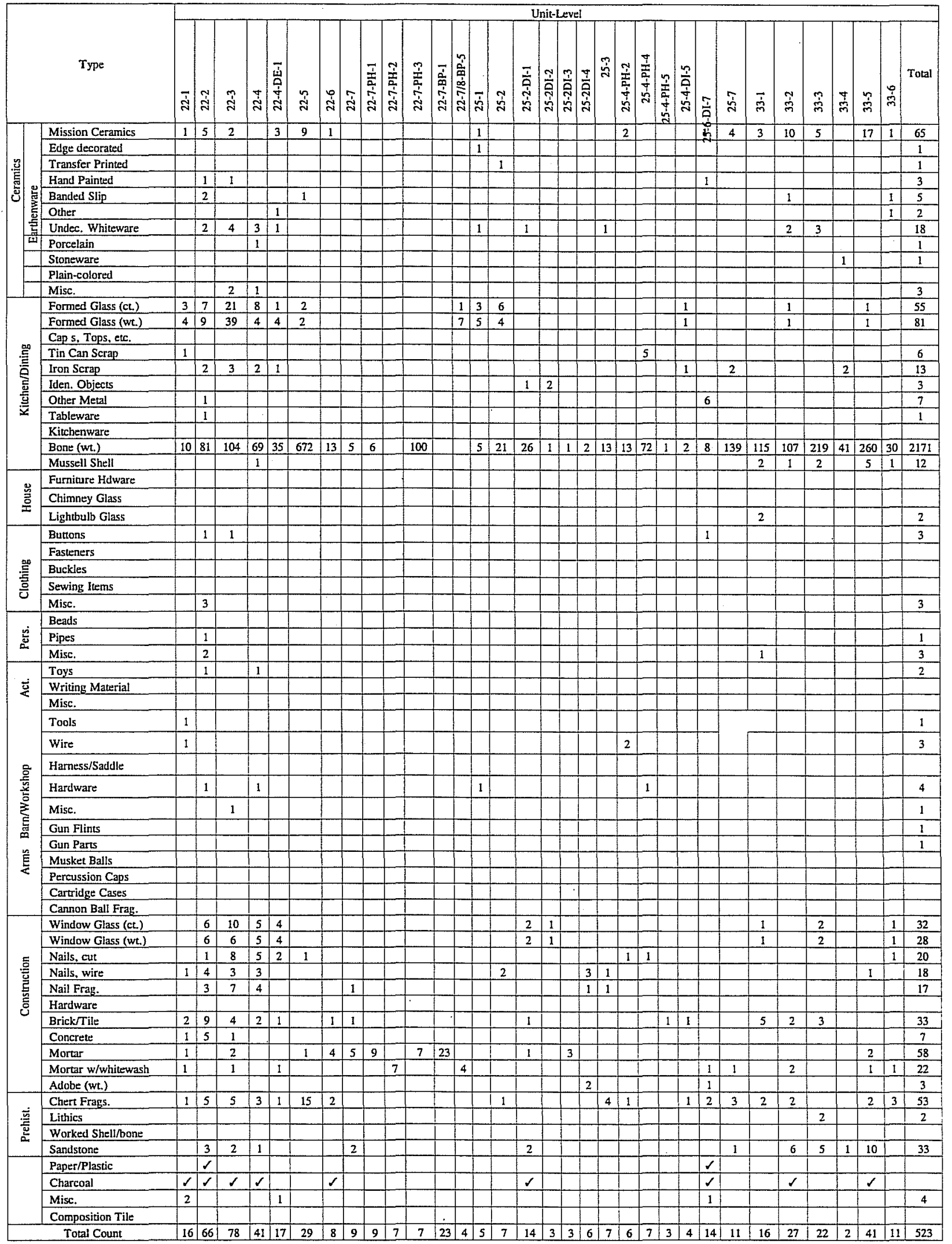


Table V-12. Ceramics from South Gate Area, Block XIII

\begin{tabular}{|c|c|c|c|c|c|c|c|c|c|c|c|c|c|c|c|c|c|}
\hline \multirow{2}{*}{\multicolumn{2}{|c|}{ Levels }} & \multicolumn{6}{|c|}{ Unit 22} & \multicolumn{4}{|c|}{ Unit 25} & \multicolumn{5}{|c|}{ Unit 33} & \multirow[b]{2}{*}{ Total } \\
\hline & & 1 & 2 & 3 & 4DE-1 & 5 & 6 & 1 & $4 \mathrm{PH}-2$ & $6 \mathrm{DI}-7$ & 7 & 1 & 2 & 3 & 5 & 6 & \\
\hline \multirow{2}{*}{ 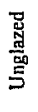 } & Goliad & & & 1 & 1 & 9 & 1 & & & 1 & 4 & & 2 & 2 & 6 & 1 & 28 \\
\hline & Valero & & & & & & & & & & & 1 & & 1 & & & 2 \\
\hline \multirow{3}{*}{ 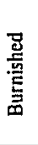 } & Blackware & & & & & & & & & & & & & & & & 0 \\
\hline & Redware & & & & & & & & & & & & & & & & 0 \\
\hline & Tonalá & & & & & & & & & & & & & & & & 0 \\
\hline \multirow{4}{*}{ 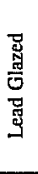 } & Galera & & & & & & & & & & & & 2 & 2 & 3 & & 7 \\
\hline & Lusterware & & & & & & & & & & & & & & 1 & & 1 \\
\hline & Olive Jar & & & & & & & & & & & & & & & & 0 \\
\hline & Sandy Paste & 1 & 2 & 1 & & & & 1 & & & & 1 & 5 & & 3 & & 14 \\
\hline & Aqua Green-on-White & & & & & & & & & & & & & & & & 0 \\
\hline & Blue and Green-on-White & & & & & & & & & & & & & & & & 0 \\
\hline & Blue-on-White & & & & 2 & & & & 1 & & - & & & & 3 & & 6 \\
\hline & Blue-on-White Double & & & & & & & & & & & & & & & & 0 \\
\hline & Blue-on-White Molded & & & & & & & & & & & & & & & & 0 \\
\hline & Faience & & & & & & & & & & & & & & & & 0 \\
\hline & Guanajuato & & & & & & & & & & & & 1 & & 1 & & 2 \\
\hline & Huejotzingo & & & & & & & & & & & & & & & & 0 \\
\hline & 19th Century Majolicas & & & & & & & & & & & & & & & & 0 \\
\hline & Monterey & & & & & & & & & & & & & & & $\cdots$ & 0 \\
\hline & Orange Band Polychrome & & 1 & & & & & & & & & & & & & $\ldots$ & 1 \\
\hline & Puebla Polychrome & & & & & & & & & & & & & & & & 0 \\
\hline & San Agustin & & & & & & & & & & & & & & & & 0 \\
\hline & San Antonio Blue-on- & & 1 & & & & & & & & & & & & & $\cdots \cdot$ & 1 \\
\hline & San Elizario & & & & & & & & & & & & & & & & 0 \\
\hline & Tucson Orange Band & & & & & & & & & & & & & & & $\ldots$ & 0 \\
\hline & Tumacacori & & & & & & & & & & & & & & & $\cdots$ & 0 \\
\hline & White & & 1 & & & & & & 1 & & & 1 & & & & & 3 \\
\hline & Total & 1 & 5 & 2 & 3 & 9 & 1 & 1 & 2 & 1 & 4 & 3 & 10 & 5 & 17 & 1 & 65 \\
\hline
\end{tabular}


Table V-13. Artifacts from Plaza Area, Block XIV

\begin{tabular}{|c|c|c|c|c|c|c|c|c|c|c|c|c|c|c|c|c|c|c|}
\hline \multirow{2}{*}{\multicolumn{2}{|c|}{ Type }} & \multicolumn{17}{|c|}{ Unit-Level } \\
\hline & & $20-1$ & $20-2$ & $20-3$ & $20-3-1$ & $20-4$ & $21-1$ & $21-2$ & $21-3$ & $23-1$ & $23-2$ & $23-3$ & $24-I$ & 24-2 & $24-3$ & $24-4$ & $24-5$ & Total \\
\hline \multirow{11}{*}{ 急 } & Mission Ceramics & 27 & & & 1 & 2 & 3 & & 17 & 1 & 19 & & & 1 & 4 & 1 & 10 & 86 \\
\hline & Edge decorated & & & & & & & & & & & & & & & & & \\
\hline & Transfer Printed & 3 & & & & & & & & & & & & & & & & 3 \\
\hline & Hand Painted & & 1 & & & & . & & 3 & & & & & & & & 1 & 5 \\
\hline & Banded Slip & & & & & & & & 5 & & & & 3 & & 1 & & 1 & 10 \\
\hline & Other & & & & & & & & 2 & & & & & & & & & 2 \\
\hline & Undec. Whiteware & 7 & & 3 & & & 2 & & 13 & 1 & & & & & & & 1 & 27 \\
\hline & Porcelain & 1 & & & & & 1 & & & & & & & & 1 & & & 3 \\
\hline & Stoneware & 1 & & 2 & & & & 1 & 4 & & & & & & & & & 8 \\
\hline & Plain-colored & & & & & & & & & & & & & & & & & \\
\hline & Misc. & 4 & & & & & & & & & & & & & & & & 4 \\
\hline \multirow{11}{*}{ 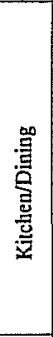 } & Formed Glass (ct.) & 80 & & 17 & 2 & & 5 & 9 & 103 & & 2 & & 5 & 2 & 4 & 2 & 30 & 261 \\
\hline & Formed Glass (wt.) & 167 & & 19 & 1 & & 12 & 10 & 653 & & 1 & & 4 & 5 & 7 & 4 & 185 & 1068 \\
\hline & Capts, Tops, etc. & 3 & & & & & 1 & & 2 & 1 & & & & & & & & 7 \\
\hline & Tin Can Scrap & 1 & & & & & & 4 & 30 & & & & & 1 & & & & 36 \\
\hline & Iron Scrap & 6 & 2 & 5 & & & 2 & & 58 & 1 & & & 1 & & 4 & & & 79 \\
\hline & Identifiable Objects & & & & & & & & 3 & & & & & & 1 & 1 & 3 & 8 \\
\hline & Other Metal & & & & & & & & 1 & & & & $\ldots$ & & & & & 1 \\
\hline & Tableware & & & & & & & & & & & & & & & & & \\
\hline & Kitchenware & & & & & & & & 1 & & & & & & & & & 1 \\
\hline & Bone (wt.) & 540 & & 95 & 20 & 1 & 64 & 18 & 283 & 17 & 600 & 107 & & & 75 & 22 & 146 & 1988 \\
\hline & Mussell Shell & 2 & & & & & & & 3 & & 2 & & & & & & 3 & 10 \\
\hline \multirow{3}{*}{ 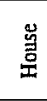 } & Furniture Hardware & 1 & & & & & & & & & & & & & & & & 1 \\
\hline & Chimney Glass & 3 & & & & & & & & & & & & & & & & 3 \\
\hline & Lightbulb Glass & & & & & & & & & & & & & & & & & \\
\hline & Buttons & 3 & & 1 & & & & & & & & & & & & & & 4 \\
\hline & Hooks, Snaps, etc. & 1 & & & & & & & & & & & & & 2 & 1 & & 4 \\
\hline 学 & Buckles & & & & & & & & & & & & & & & & & \\
\hline 它 & Sewing Items & & & & & & & & & & & & & & & & & \\
\hline & Misc. & & & & & & & & & & & & & & & & & \\
\hline & Beads & & & & & & 1 & & & & & & & & & & & 1 \\
\hline$\frac{5}{5}$ & Pipes & & & & & & & & & & & & & 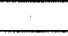 & & & & \\
\hline & Misc. & & & & & & & & 1 & & & & & & & & & 1 \\
\hline & Toys & 1 & & & & & & & 1 & & & & & & & & & 2 \\
\hline$\dot{\vec{g}}$ & Writing Material & & & & & & & & & & & & & & & & & \\
\hline & Misc. & 1 & & & & & & & & & & & & & & & & 1 \\
\hline & Tools & & & & & & & & 1 & & & & & & & & & 1 \\
\hline 矛 & Wire & 1 & & 1 & & & & 2 & 6 & & & & & & 1 & & & 11 \\
\hline 홓 & Harness/Saddle & & & & & & & & & & & & & & & & & \\
\hline E & Harware & 2 & & 2 & & & & & 3 & 1 & & & & 1 & 1 & & & 10 \\
\hline$m$ & Misc. & 5 & 1 & & & & & & & 1 & & & & & & & & 7 \\
\hline & Gun Flints & 1 & & & & & & & & & & & & & & & & 1 \\
\hline & Gun Parts & & & & & & & & & & & & & & & & & \\
\hline & Musket Balls & & & & & & & & & & & & & & & & & \\
\hline$\frac{E}{<}$ & Percussion Caps & & & & & & & & & & & & & & & & & \\
\hline & Cartridge Cases & & & & & & & & & & & & & & & & & \\
\hline & Cann on Ball Frag. & & & 1 & & & & & & & & & & & & & 1 & 2 \\
\hline & Window Glass (ct.) & 12 & & 3 & & & 4 & & 7 & 4 & & & & 1 & 5 & 9 & 7 & 52 \\
\hline & Window Glass (wt.) & 25 & & 2 & & & 4 & & 4 & & 1 & & & 1 & 2 & 13 & 14 & 66 \\
\hline & Nails, cut & 4 & & 12 & & 1 & 2 & 1 & 16 & 1 & & & & 1 & & 2 & 3 & 43 \\
\hline & Nails, wire & 10 & & 4 & & & 1 & 3 & 11 & & & & & 2 & 3 & 4 & & 38 \\
\hline E & Nail frag. & 2 & & 4 & & & & & 4 & & & & & & 2 & 7 & 1 & 20 \\
\hline 苞 & Hardware & & & & & & & & & 1 & & & & & & & & 1 \\
\hline 吉 & Brick/Tile & 131 & & 32 & & & 38 & & 17 & & 4 & 4 & & & & 3 & 5 & 234 \\
\hline 8 & Concrete & 10 & & 20 & & & & 7 & & & & & & & & 6 & & 49 \\
\hline & Mortar & & & & & & & & 1 & & 1 & & & & & & & 2 \\
\hline & Mortar w/whitewash & 7 & & & & & & 8 & 8 & & & & & 1 & 1 & 30 & & 55 \\
\hline & Adobe (wt.) & & & & & & & & & & & & & & & & & \\
\hline & Chert Frags. & 13 & & 4 & & 2 & 3 & 2 & 13 & 5 & 30 & 11 & 1 & 1 & 5 & & & 90 \\
\hline 啇 & Lithics & & & 1 & & & & 2 & & & & & & & & & & 3 \\
\hline 㐫 & Worked Shell/bone & & & & & & & & & & & & & & & & & \\
\hline & Sandstone & 21 & & & & & 5 & 1 & 14 & 2 & 2 & & & & 1 & & 3 & 49 \\
\hline & Paper/Plastic & $\underline{v}$ & & & & & $\checkmark$ & $\checkmark$ & $\checkmark$ & & & $\checkmark$ & & & & $\checkmark$ & & \\
\hline & Charcoal & & & & & & & & $\checkmark$ & & $\checkmark$ & & & & $\checkmark$ & & & \\
\hline$\stackrel{\text { 总 }}{=}$ & Misc. & & & & & & & & & & & & & & & & & \\
\hline & Composition Tile & 19 & & & & & 1 & & & & & & & & & & & 20 \\
\hline & Total Count & 383 & 4 & 118 & 3 & 5 & 69 & 40 & 348 & 19 & 60 & 11 & 14 & 10 & 35 & 68 & 69 & 1256 \\
\hline
\end{tabular}


Table V-14. Ceramics from Plaza Area, Block XIV

\begin{tabular}{|c|c|c|c|c|c|c|c|c|c|c|c|c|c|c|}
\hline & \multirow{2}{*}{ Levels } & \multicolumn{3}{|c|}{ Unit 20} & \multicolumn{2}{|c|}{ Unit 21} & \multicolumn{2}{|c|}{ Unit 23} & \multirow[b]{2}{*}{1} & \multirow[b]{2}{*}{2} & \multirow[b]{2}{*}{3} & \multirow[b]{2}{*}{4} & \multirow[b]{2}{*}{5} & \multirow[b]{2}{*}{ Total } \\
\hline & & 1 & 3PT-1 & 4. & 1 & 3 & 1 & 2 & & & & & & \\
\hline \multirow{2}{*}{ 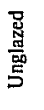 } & Goliad & 14 & & 1 & 2 & 5 & & 14 & & 1 & 1 & & 5 & 43 \\
\hline & Valero & & & & & & & & & & 1 & & & 1 \\
\hline \multirow{3}{*}{ 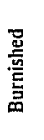 } & Blackware & & & & & & & & & & & & & 0 \\
\hline & Redware & 1 & & & & & 1 & & & & & & 1 & 3 \\
\hline & Tonalá & & & & & & & & & & & & & 0 \\
\hline \multirow{4}{*}{ 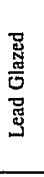 } & Galera & 1 & 1 & 1 & & 1 & & & & & & & 1 & 5 . \\
\hline & Lusterware & & & & & & & & & & & & & 0 \\
\hline & Olive Jar & & & & & & & & & & & & & 0 \\
\hline & Sandy Paste & 4 & & & & 1 & & & & & 1 & 1 & 1 & 8 \\
\hline \multirow{18}{*}{ 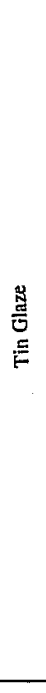 } & Aqua Green-on-White & & & & & & & & & & & & & 0 \\
\hline & Blue and Green-on-White & & & & & 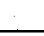 & & & & & & & & 0 \\
\hline & Blue-on-White & 4 & & & 1 & 4 & & 2 & 1 & & 1 & & & 13 \\
\hline & Blue-on-White Double & & & & & & & & & & & & & 0 \\
\hline & Blue-on-White Molded & & & & & & & & & & & & & 0 \\
\hline & Faience & & & & & & & & & & & & & 0 \\
\hline & Guanajuato & & & & & 1 & & & & & & & & 1 \\
\hline & Huejotzingo & 1 & & & & & & & & & & & & 1 \\
\hline & 19th Century Majolicas & & & & & & & & & & & & & 0 \\
\hline & Monterey & & & & & & & & & & & & $\cdots$ & 0 \\
\hline & Orange Band Polychrome & 1 & & & & & & & & & & & 1 & 2 \\
\hline & Puebla Polychrome & & & & & & & & & & & & & 0 \\
\hline & San Agustin & & & & & & & & & & & & $\cdots$ & 0 \\
\hline & San Antonio Blue-on- & & & & & & & & & & & & $\cdots$ & 0 \\
\hline & San Elizario & 1 & & & & & & & & & & & & 1 \\
\hline & Tucson Orange Band & & & & & & & & & & & & & 0 \\
\hline & Tumacacori & & & . & & & & & & & & & & 0 \\
\hline & White & & & & & 5 & & 3 & & & & & 1 & 9 \\
\hline & Total & 27 & 1. & 2 & 3 & 17 & 1 & 19 & 1 & 1 & 4 & 1 & 10. & 87 \\
\hline
\end{tabular}




